The Wairarapa Wealthy in Public and Private, 1876-1913

\author{
By
}

\title{
Joseph Cruden
}

A thesis submitted to Victoria University of Wellington in fulfilment of the requirements for the degree of Master of Arts in History

Victoria University of Wellington 



\begin{abstract}
Social histories of New Zealand's colonial wealthy usually focus on those who left personal papers, ignoring those who left no major records. What is more, histories of the wealthy have tended to focus on the South Island-there is no reason to assume that the North Island rich were the same. This thesis attempts to address both these imbalances by approaching wealthy individuals in colonial Wairarapa systematically_locating all testators who died between 1876 and 1913, leaving estates worth $£_{110,000}$ or more. This process produces a cohort of sixty-five, mainly farmers and mostly of middle-class origins. Testamentary records demonstrate that in private, the rich stayed true to their origins by splitting their wealth evenly. Other forms of biographical information, most notably newspaper obituaries and Cyclopedia entries, show that public life was different. Here, the rich departed from their origins; whereas community involvement and charitable works had been an important aspect of middle-class identity in Britain, the colonial experience forced wealthy capitalists to redefine public status. Throughout, this thesis demonstrates the importance of regional social histories in New Zealand by thinking 'under as well as across the nation'-extending South Island scholarship of the wealthy into the North Island and examining the manifestation of large historical forces close-up in communities of individuals.
\end{abstract}




\section{Table of Contents}

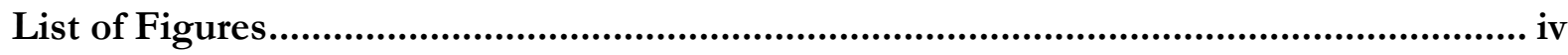

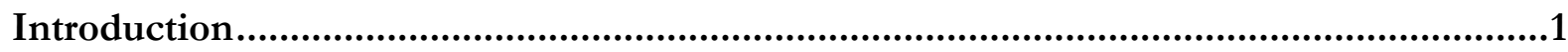

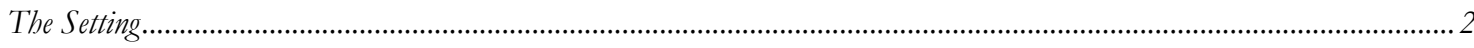

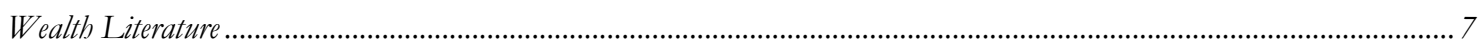

Probates as Historical Source — a Systematic Approach …………………………………………………………... 9

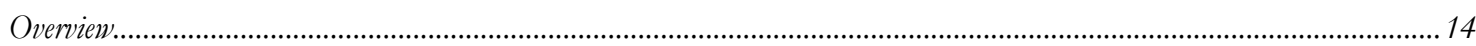

Chapter One: An Anatomy of Wairarapa Wealth ..........................................................17

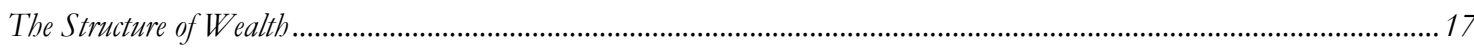

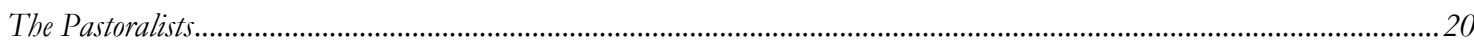

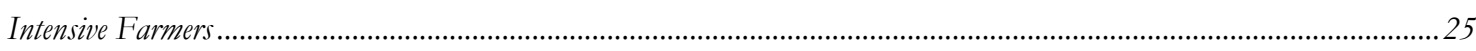

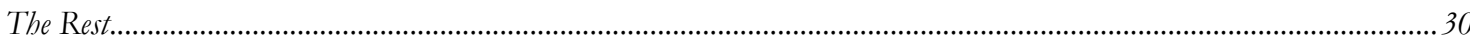

Origins

The Extent \& Distribution of Wealth in Wairarapa …………………………………………………………...... 38

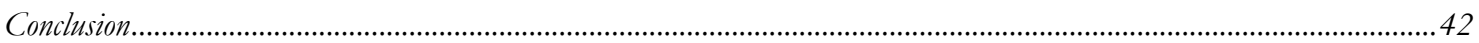

Chapter Two: 'Matters of account between us'-Wealth and Family in the Testamentary Record ........................................................................................................42

The Family in the Will—Bequeatbing Property, Bequeathing Values .........................................................................46

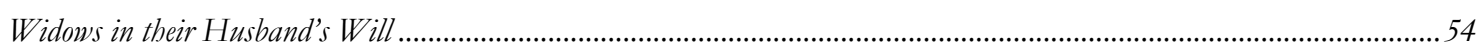

Testamentary Custom and Practice................................................................................................................... 62

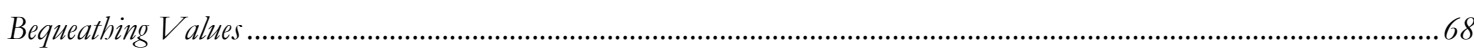

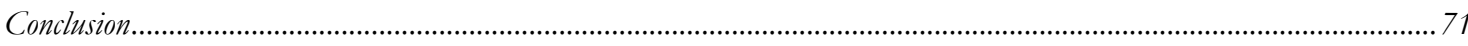

Chapter Three: 'A keen interest'?_The Wairarapa Wealthy in Their Community ..........73

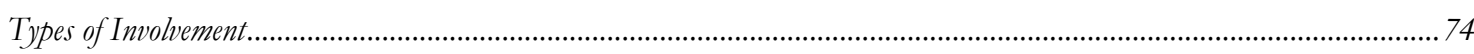

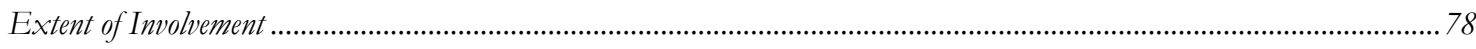

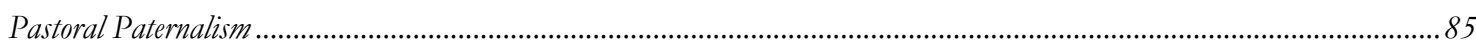

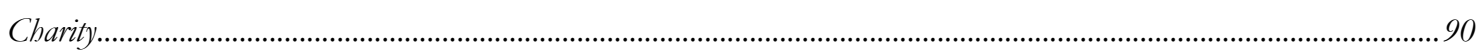

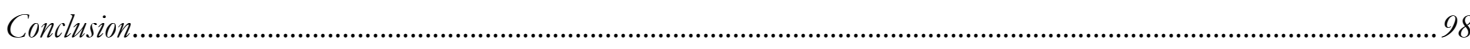

Conclusion: Thinking Under and Across the Nation ...................................................99

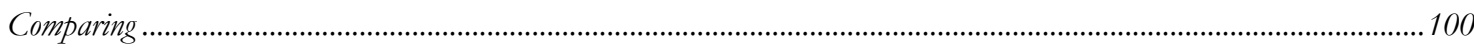

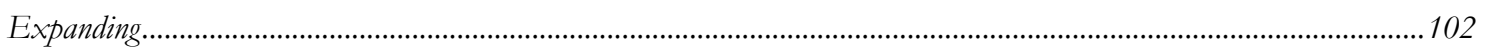

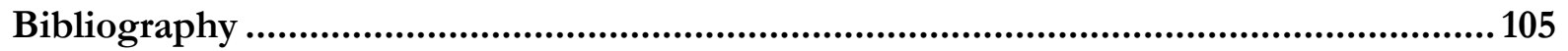




\section{List of Figures}

Figure 1: Map of Wairarapa …………………….................................................................

Figure 2: Distribution of Estate Values in New Zealand, 1893-1910................................11

Figure 3: Wealth by Age Bracket, 1912 ................................................................................13

Figure 4: The Wealthy Wairarapa Testators ..........................................................................18

Figure 5: Occupational Breakdown of the Wairarapa Wealthy ...........................................19

Figure 6: Class Origins of the Wealthy Wairarapa Testators ..................................................34

Figure 7: The Geographic Origins of the Wealthy Wairarapa Testators .............................37

Figure 8: Value of Wairarapa Wealthy Testator's Estates, 1876-1913 _...............................39

Figure 9: Value of Wairarapa Wealthy Testator's Estates 1876-1913 without Edward

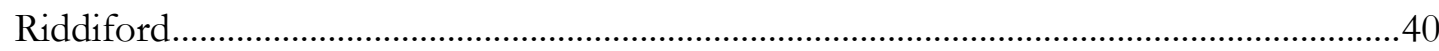

Figure 10: Breakdown of Wealth among Testators............................................................41

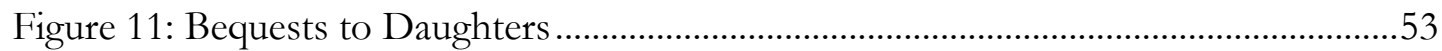

Figure 12: Relative Size of Bequests to Sons and Daughters................................................53

Figure 13: Bequests to Widows .........................................................................................5

Figure 14: Community Involvement of Wairarapa Wealthy ................................................79

Figure 15: Mayors in Masterton, Carterton and Greytown, 1877-1900 .............................82

Figure 16: County Chairmen in Wairarapa, 1900-1910.......................................................85 


\section{Acknowledgements}

I owe a great debt to my supervisor, Jim McAloon. I was first introduced to this topic during conversations in Jim's Honours course at Victoria University in 2013. These conversations inspired me, and demonstrated that Wairarapa was a useful site for regional study. Jim's ideas, comments and reassurances, expressed throughout Honours and during the supervision of my research were always timely and invariably considerate. I thank Jim for his vital contribution to this thesis.

The History Department at Victoria University has been a friendly and welcoming work environment and has provided me with support and employment throughout. My fellow post-graduate students in particular deserve thanks for their solidarity and company throughout the year. They made an experience that was occasionally lonely and often difficult seem worthwhile.

Finally, I owe personal debts. I would like to thank my parents, John Cruden and Sue Mitchell, whose years of support, encouragement and sympathy made this possible. I would also like to thank my brother Daniel for reading several drafts and for providing thoughtful comments under some pressure. Thanks, also, to my sister Jenny for her willingness to express sympathy and provide distraction from afar. My friends beyond the university-James, Elliot and George-remained patient and assumed attitudes of attention when it was easier not to.

Lastly, I owe a debt to my partner Nicola, who continued to demonstrate her capacity for support and sympathy throughout the thesis. Nicola deserves thanks, in particular, for her willingness to provide eyes and ears despite the pressures of her own research. 
Figure 1: Map of Wairarapa

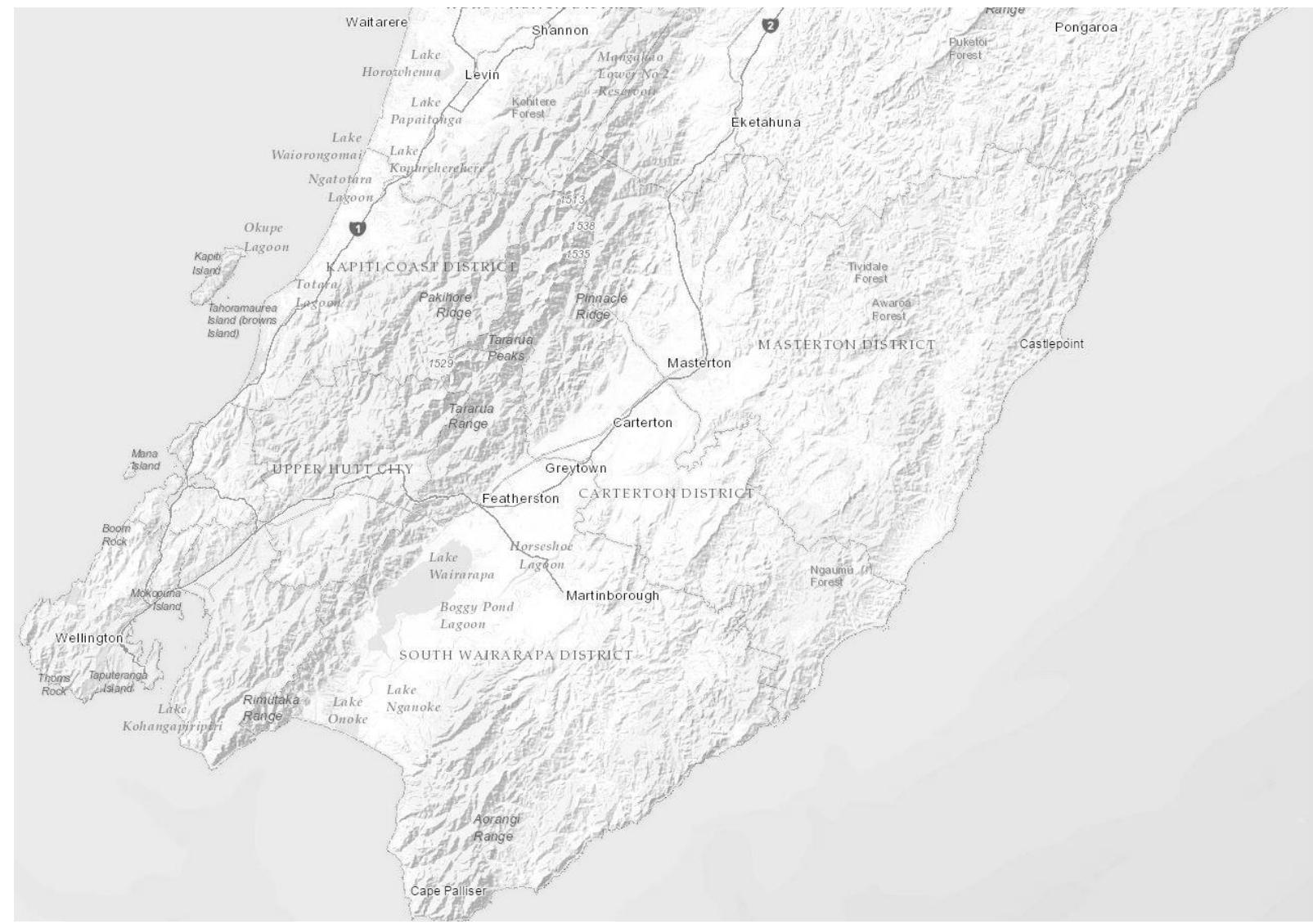

Map created using Wairarapa Combined District Map Viewer, URL: mapping.gw.govt.nz/Wairarapa/; accessed on 29 April 2015 


\section{Introduction}

James Wrigley (1825-1904) was a bootmaker and farmer near Masterton in Wairarapa, Wellington's isolated hinterland. Wrigley was a colonist, but his experiences were different to those of European settlers stocking runs in the South Island-he was, for example, a member of the Small Farms Association, which settled Masterton democratically. Other aspects of Wrigley's identity were common to New Zealand settlers. Most notably, Wrigley was shaped by a tension between his origins and his destination: his father had been a weaver of humble means, but, by the time of his death, Wrigley was rich-his estate was valued at $£ 13,534$. Which would dominate his identity, the modesty of his origins or the wealth of his later life? It is difficult to know because unfortunately, little evidence remains; if Wrigley wrote letters or kept a diary, these records have not survived. The only pieces of real historical evidence are Wrigley's will and a short obituary in the Wairarapa Daily Times, which describes him as a man of 'quiet, genial and unassuming disposition.'

In James Wrigley's case, this record may be little to go by but, fortunately, he was not alone. Wrigley was one of sixty-five in Wairarapa to leave an estate worth $£, 10,000$ or more between 1876 and 1913. This thesis uses both these records-the will and the obituary (supplemented by other biographical material where available) — and all sixty-five testators in order to 'zoom out' and allow the structure and culture of Wairarapa wealth to come in to view. In particular, this systematic approach provides two significant insights. First, we see the wealthy at home, in their private lives. Here, the wills of the Wairarapa wealthy demonstrate that overwhelmingly, wealth was about the family. We also see the activities of the rich in public - their roles in the community (however they may have defined it) and their willingness (or lack thereof) to contribute to charitable causes.

These records, unique in their universality, demonstrate the complex identities of Wrigley and the rest of his cohort of rich testators-exploring the role that tension between origins and destination had in shaping wealthy consciousness. In private, the wealthy represented their origins, demonstrating a middle-class approach to wealth and the

1 ‘Obituary', Wairarapa Daily Times, 23 May 1905, p.5. 
family. Outside the home, however, the wealthy departed from middle-class tradition; they tended to be less involved in public life.

\section{The Setting}

This thesis is informed by an understanding that place matters and a belief in the importance of regional studies. Analytical social histories of colonial New Zealand tend to be written from a national viewpoint, neither putting New Zealand in perspective nor looking at regional variation. ${ }^{2}$ In his recent Webs of Empire, Tony Ballantyne calls for colonial New Zealand histories that 'think under as well as across the nation.' In its focus on Wairarapa-Wellington's pastoral hinterland and a useful site for studying the wealthy in rural areas - this thesis represents such a history. Being a regionally-focussed, rather than a regional history, this thesis does not provide an extensive study of Wairarapa's past, but important aspects of the region's geography and history might be highlighted.

Wairarapa is in the North Island's south-eastern corner. The region is separated from Wellington and the North Island's west coast by the Rimutaka and Tararua ranges; to the east lie hilly uplands and the Pacific Ocean. Since European settlement in the 1840s, Wairarapa's most populous area has been the expansive basin that runs due south-west down the Lower North Island. While its southern, eastern and western extremities are clearly defined by Cook Strait, the ranges and ocean respectively, Wairarapa's northern borders are not well-defined. ${ }^{4}$ For the purposes of this analysis, Wairarapa has been defined (somewhat arbitrarily) as the geographical area of the North Island to the east of the Rimutaka and Tararua ranges and south of Cape Turnagain near Herbertville.

The initial struggles of the New Zealand company settlement of Wellington led to a pastoral exodus to Wairarapa, followed by that region's settlement. The key shortcoming

\footnotetext{
2 There are fine exceptions to this, of course. Lydia Wevers, Reading on the Farm: Victorian Fiction and the Colonial World, (Wellington, 2010) and Robert Peden, Making Sheep Country: Mt Peel Station and the Transformation of the Tussock Lands (Auckland, 2011) are two recent publications that buck this trend.

3 Tony Ballantyne, Webs of Empire, (Wellington, 2012) p.246 Ballantyne is only the most recent historian to argue for a regional focus. He owes a debt to W. J. Gardner, who was arguing for the importance of regional studies to New Zealand social history as early as 1957. W. J. Gardner, Where They Lived: Studies in Local, Regional and Social History, (Christchurch, 1999).

4 The difficulties of defining the region's historical boundaries are discussed in the Waitangi Tribunal's Wairarapa Ki Tararua report. Waitangi Tribunal, The Wairarapa Ki Tararua Report, (Wellington, 2010) pp. xlixlvii.
} 
of the Wellington settlement at Port Nicholson was the New Zealand Company's failure to ensure the land was suitable for their proposed agricultural settlements; as it turned out, the land (that which was not covered in bush) was most suited to pastoralism. 'Squatting' began to dominate as those who had arrived from New South Wales and Van Diemen's Land with stock occupied such open land as was available in Wellington (many could not access the New Zealand Company's London land offers). ${ }^{5}$

As land for grazing ran out, the pastoralists were placed under increasing pressure. In 1842, Samuel Revans complained in his New Zealand Gazette that:

the continued arrival of ship loads of cattle, create what may be termed a pressure from without. There is now a strong feeling that the pasturage about the town, will soon be unequal to the demands of the stock imported, and the question is where to place them. ${ }^{6}$

In the period 1843-1844, the number of sheep grazing in and around Port Nicholson had nearly doubled. Clearly, pastoralists would have to look further afield.

Wairarapa represented 'the mecca for pastureless stock-owners loitering on the bush-covered hills of Wellington. ${ }^{7}$ Robert Stokes, a New Zealand Company surveyor, crossed the Rimutakas with a company of five others on 25 November 1841, and spent seven days in the basin, reporting that

As soon as convenient a road shall be made, there is a level tract of upwards of three hundred square miles, or nearly double the quantity required for all the preliminary sections, of land of the best description, that may be brought under cultivation at the least possible expence. ${ }^{8}$

The Colonist argued in its maiden edition, 'Let the district in question be made accessible, either by a road along the valley of the Hutt, or if that be impracticable, then by a road along the Manewatu' allowing those 'cramped for space' to 'act as pioneers of settlement.'

\footnotetext{
5 Brad Patterson, 'Laagers in the Wilderness: The origins of pastoralism in the southern North Island districts, 1840-55', Stout Centre Review, vol.1, no.3, 1991, p.6.

${ }^{6}$ New Zealand Gazette and Wellington Spectator, 29 June 1842, p.2.

7 A.G. Bagnall, Wairarapa: An Historical Excursion, (Masterton, 1976), p.24.

${ }^{8}$ Robert Stokes, 'Report of the Expedition to Wairarapa', New Zealand Gazette and Wellington Spectator, 18 Dec 1841, p.3.

${ }^{9}$ Editorial, New Zealand Colonist and Port Nicholson Advertiser, 2 August 1842, p.2.
} 
Although a road over the Rimutakas was chosen, progress was slow and pastoralists remained frustrated at the Company's refusal to purchase land for runs in Wairarapa.

Eventually pastoralists took matters into their own hands and from 1845, they began making the trek to Wairarapa to arrange leases with iwi. Brad Patterson situates the arrangement of these leases in the wider exodus from Wellington but notes that 'without doubt, Wairarapa Valley proved the most popular destination for the early pastoralist 'trekkers'.' An April 1845 Wellington Independent article lists twelve runs already in operation. ${ }^{11}$ Patterson reports that by late 1848 , there were thirty-three independent runs. This 'sub-phase', Patterson's 'era of illegal occupations', ended in 1850 when the government took action to halt the signing of further illegal leases.

This Wairarapa Māori-leaseholder economy eventually gave way under pressure from the colonial government. ${ }^{12}$ In forty-one purchases over seven months (1853-1854), the Crown acquired one and a half million acres of Wairarapa land. Crown land-purchaser Donald McLean entered the scene in 1853, moving south after successful purchases in Hawke's Bay. After initial purchases on the Upper East Coast, the majority of Wairarapa was sold after an 1853 hui attended by Governor George Grey and McLean. ${ }^{13}$ All told, McLean handed over $£ 23,457$ for the majority of Wairarapa. ${ }^{14}$

Recently, the legacy of Donald McLean and the Wairarapa purchases has been revised by historians. The region's great biographer, A. G. Bagnall, writing in 1976, saw McLean as a 'supreme pakeha diplomat', and argued that 'the purchases were reasonably negotiated and in themselves defensible. How the pakeha met this continuing obligation was perhaps another story. ${ }^{, 15}$ McLean's 2004 biographer, Ray Fargher, disagrees. Although Fargher acknowledges that McLean had a powerful reputation as a negotiator, he frames McLean as a tool of the crown, and an individual fundamentally opposed to Māori

\footnotetext{
${ }^{10}$ Patterson, p.7.

${ }^{11}$ Bagnall, pp.59-60.

${ }^{12}$ For a discussion of the incommensurability of Pākehā and Māori conceptions of property, and the ways in which European understandings informed the Crown's land policy, see John Weaver, 'Frontiers into Assets: The Social Construction of Property in New Zealand 1840-65', The Journal of Imperial and Commonwealth History, vol. 27, no. 3, 1999, pp.17-54.

13 Bagnall, p.99.

${ }^{14}$ Ray Fargher, 'The best man who ever served the crown', The Life of Donald McLean, (Wellington, 2004), p.125.

${ }^{15}$ Bagnall, p. 90 \& p.107.
} 
lessors. ${ }^{16}$ Of the purchases themselves, Fargher argues that they represented a decline in standards: 'McLean's land purchases in Hawke's Bay and Wairarapa between 1853 and 1859 show the changes in his approach and how these negotiations began to unravel. ${ }^{, 17}$ In his 1999 'Frontiers into Assets', John Weaver labelled McLean's 1853 Wairarapa purchases 'an interesting performance by a clever man who exploited his fine understanding of Maori language and customs. ${ }^{, 18}$ In 2010, the Waitangi Tribunal found first that the crown failed to meet its obligation to support the Māori-leaseholder economy, and second that the crown knowingly negotiated the sale of reserves from individuals who were not representative of the larger group. ${ }^{19}$

The effect of the purchases was to legitimise the hitherto 'illegal' occupation of land by pastoralists and the now-legal runs were joined in Wairarapa by towns, which began to crop up in the valley under various schemes. ${ }^{20}$ Masterton and Greytown were founded in 1854 by the Small Farms Association, a group of frustrated smaller farmers from Wellington and the Hutt Valley. ${ }^{21}$ Small Farms settlers would receive a one-acre town section and a 40-acre suburban section. They hoped that their small, intensive farms would prove a viable alternative to large-scale pastoralism. After lagging behind, Masterton overtook Greytown to become Wairarapa's dominant town.

The Small Farms settlements of Greytown and Masterton were joined by other new towns. Carterton was settled by road-workers cutting a road through Three-Mile Bush between Greytown and Masterton. Featherston, at the foot of the Rimutakas, was surveyed by the government in 1856 and survived after the initial auction of sections failed. ${ }^{22}$ Martinborough also grew slowly, having been sold in sections by wealthy

\footnotetext{
${ }^{16}$ Fargher, p.126.

${ }^{17}$ Fargher, p.167.

18 Weaver, p.38.

19 Waitangi Tribunal, The Wairarapa Ki Tararua Report, pp.1045-1046.

20 The Crown claimed that the pre-emptive right in article 2 of the Treaty of Waitangi made Māori leaseholding illegal. The 2010 Waitangi Tribunal report demonstrated that by extending the definition of 'pre-emption' after the fact, the Crown failed to act 'in good faith' towards Māori and that, further, making leases illegal so as to encourage sale was a 'serious breach of Māori rights under article 2.' Waitangi Tribunal, The Wairarapa Ki Tararua Report, pp.77-88.

${ }^{21}$ A discussion of the Small Farms Association can be found in Chapter one.

22 Bagnall, pp.162-163.
} 
runholder James Martin in $1879 .^{23}$ During the 1870s, Wairarapa's arable land expanded as Forty Mile bush began to be cleared, chiefly by Scandinavians brought in under Julius Vogel's programme of public works. ${ }^{24}$ Those working on clearing the bush populated settlements of their own, the most successful of these being Eketahuna.

Non-pastoral settlers in and around the new towns began to diversify Wairarapa's pastoral economy. ${ }^{25}$ Small farmers turned increasingly to mixed farming (both planting crops and stock-farming) and a few tried their hands at dairying. Others began to fell native bush and made fortunes in sawmilling. Eventually, the settlements evolved into service towns and rural businesses such as post offices, saddleries, blacksmiths and stock agents began to crop up. As towns grew and began to take on lives of their own, rural storekeepers were joined by members of the professional classes.

The above regional history is sufficient to highlight several key factors that mark Wairarapa as both reflecting and contradicting national trends, making it a useful site for regional study. First, pastoralism was important to Wairarapa's settlement. In this fashion, Wairarapa is typical of New Zealand's leeward ecoregion-the area most suited to pastoralism. ${ }^{26}$ This similarity encourages comparison with Canterbury and Otago, two other regions on New Zealand's leeward side and the location of existing scholarship. Second, Wairarapa was uncommonly isolated and exclusively rural. While Canterbury and Otago had accessible hinterlands, Wairarapa was separated from Wellington by the Rimutaka and Tararua ranges. Wairarapa's rurality marks it as a unique location in New Zealand and an important site for study of rural communities. Third, settlement patterns in Wairarapa were uncommon. Elsewhere, towns were much less likely to be founded by democratic groups such as the Small Farms Association.

\footnotetext{
${ }^{23}$ Roberta McIntyre, Canoes of Kupe: A history of Martinborough District, (Masterton, 2002), pp.109-126.

${ }^{24}$ Bagnall, pp.251-266.

${ }_{25}$ Chapter one will discuss the accumulation strategies pursued by some of these small farmers and other non-pastoral wealth holders.

26 Matt McGlone, 'Ecoregions - Nine ecoregions', Te Ara - the Encyclopedia of New Zealand, available at http:/ /www.teara.govt.nz, updated 13 July 2012 New Zealand's leeward side is all that land to the east of the New Zealand's central spine. In the South Island, that is all of Canterbury and Otago to the east of the Southern Alps. In the North Island it is that land in Wairarapa and Hawke's Bay to the east of the North Island's volcanic plateau. The leeward regions are particularly sunny and dry.
} 
This, then, is the setting in which the Wairarapa wealthy lived and within which this history operates. Taken together, the factors above provide powerful opportunities for comparison and expansion. In particular, this thesis compares the Wairarapa wealthy with the wealthy in Canterbury and Otago, already the subject of research by Jim McAloon. By eyeing the consistencies and inconsistencies between the wealthy in Wairarapa and those elsewhere in New Zealand, we might move towards a more complete social history of wealth and the wealthy. ${ }^{27}$

\section{Wealth Literature}

A survey of the existing scholarship on the wealthy-at the local and national levelsdemonstrates that this thesis is an import addition to the historiography. In particular, this thesis contextualises existing local work by analysing all the wealthy systematically, while also expanding South Island research into the North Island.

There is no systematic work on the Wairarapa wealthy, but existing scholarship of the Wellington Region has identified an aristocratic streak, especially among the wealthy pastoralists. Roberta McIntyre, in the only history of the wealthy in wider Wellington, has identified the existence of a 'milieu' of wealthy elite enjoying political influence, power and social exclusivity. ${ }^{28}$ Of course, McIntyre was only interested in those who spent a lot of time in Wellington - a group that is only a minority of those under analysis here. Further north, a $1972 \mathrm{PhD}$ thesis by Michael Campbell characterised successful farmers in Hawke's Bay as belonging to 'landed society'. ${ }^{29}$ Both McIntyre and Campbell focus on selfselecting samples of social elites and as such do not analyse the identity of all the wealthy. ${ }^{30}$

\footnotetext{
27 This recalls Gardner's argument for the value of regional history: 'A series of advanced regional studies may yield better results in social history than the analysis of national statistics. At least one can claim that the two should be complementary, especially if the basic aim is what it should be: to understand New Zealanders in their daily lives.' Gardner, p.25.

28 McIntyre's thesis was written under former name. Roberta Nicholls, 'Wellington Magnate: The Honourable John Martin, his Children and their Milieu, 1841-1918', MA Thesis, Victoria University of Wellington, 1985.

${ }^{29}$ Michael Campbell, 'The Evolution of Hawke's Bay Landed Society, 1850-1914', PhD Thesis, Victoria University of Wellington, 1972

30 McIntyre, Campbell and others, most notably Stevan Eldred-Grigg, have also tended to ignore the fact that attempts to ape gentry life were a characteristic of successful middle-class professionals prior to the colonial experience, see F. M. L. Thompson, 'How Successful Nineteenth-Century Businessmen Disposed of Their Fortunes', The Economic History Review, vol. 43, no. 1, 1990, pp.40-61.
} 
Wairarapa's regional and family histories are most useful as case studies and as directors of research. Bagnall favoured description over analysis in general and made no comment on the Wairarapa wealthy as a group, preferring to focus on individual accounts of pastoral and mercantile success. ${ }^{31}$ Bagnall's extensive appendices, lists and accounts of early pastoralism in the region have served as invaluable entry points into the Wairarapa wealthy. McIntyre, who has also written a history of the Martinborough District, is similarly useful, although her work has the disadvantage (in this context) of being restricted to southern Wairarapa. ${ }^{32}$ Family histories, such as David Yerex's account of the Beethams at Brancepeth, are similarly descriptive and are of most use as case studies of wealthy individuals and families. ${ }^{33}$

There is no systematic study of the rich in New Zealand on a national scale. Margaret Galt's $1985 \mathrm{PhD}$ thesis remains the most exhaustive study of wealth in New Zealand, but her work was strictly statistical. ${ }^{34}$ Graeme Hunt's The Rich List focuses on describing (and deifying) New Zealand's historical wealthy. ${ }^{35}$ Stevan Eldred-Grigg's The Rich is similarly selective in its source material, painting an elaborate portrait of an extravagant and aristocratic New Zealand rich. ${ }^{36}$ Eldred-Grigg's study followed on from his earlier account of southern pastoral wealth, A Southern Gentry, in which he claimed the 'great sheep lords' of Canterbury and Otago were Old World aristocrats. ${ }^{37}$ National biographers have tended to vary between reinforcing the egalitarian myth, in which the importance of class in the colony is downplayed, and a regurgitation of Eldred-Grigg's claims of a New Zealand gentry. ${ }^{38}$

\footnotetext{
${ }^{31}$ A.G. Bagnall, Wairarapa: An Historical Excursion, (Masterton, 1976).

${ }^{32}$ Roberta McIntyre, Canoes of Kupe: A bistory of Martinborough District, (Masterton, 2012).

${ }_{33}$ Notable examples include: David Yerex, They Came to Wydrop: the Beetham and Williams Families, Brancepeth and Te Parae, Wairarapa 1856-1990, (Wellington, 1991); Paul Goldsmith, The Bidwills, (Auckland, 2012); Dorothea Joblin, The Colonial One: Lorna Monckton of Newstead, (Wellington, 1975).

34 Margaret Galt, 'Wealth and Income in New Zealand, c.1870-c.1939', PhD Thesis, Victoria University of Wellington, 1985

35 Graeme Hunt, The Rich List: Wealth and Enterprise in New Zealand 1820-2000, (Auckland, 2000).

${ }^{36}$ Stevan Eldred-Grigg, The Rich, (Wellington, 1996).

${ }^{37}$ Stevan Eldred-Grigg, A Southern Gentry, (Christchurch, 1980).

${ }^{38}$ For the former, see Michael King, Penguin History of New Zealand, (Wellington: Penguin, 2003) and Keith Sinclair, A History of New Zealand, (Auckland, 1959). For the latter see James Belich, Making Peoples: A History of the New Zealanders from Polynesian Settlement to the end of the nineteenth century, (Auckland, 1996).
} 
The only systematic history of the wealthy in New Zealand (and most direct methodological inspiration for this thesis) focused on the South Island. Jim McAloon's No Idle Rich demonstrated that the wealthy in Canterbury and Otago tended to come from the middle and lower middle classes and reflected this in their approach to economic life. ${ }^{39}$ In contrast to the opulence of Eldred-Grigg's wealthy, McAloon's rich were far from idle; they favoured hard work over passive profits. Overall, McAloon's wealthy demonstrated an adherence to 'Calvinist values of sobriety, thrift and deferred gratification. ${ }^{40}$

This thesis, then, extends McAloon's study into the North Island, allowing opportunities for comparison throughout. Within Wairarapa, it helps to place existing scholarship (slim though it is) in context by systematically analysing all those who died between 1876 and 1913, leaving an estate worth $£ 10,000$ or more.

\section{Probates as Historical Source - a Systematic Approach}

This thesis utilises all sixty-five probate files belonging to individuals who died between 1876 and 1913 worth $£ 10,000$ or more in order to analyse the wealthy systematically. ${ }^{41}$ The 'traditional record' — chiefly consisting of diaries and correspondence-tends to identify a self-selecting group; those who did not leave such evidence (likely to be the more industrious and modest) can easily be ignored. Clearly, a more systematic approach is required. A look at the available material on wealth holding in New Zealand demonstrates that while imperfect, probates are the only useful source with which to identify wealthy individuals systematically.

We must first clarify what we mean by rich for there were multiple ways of being wealthy. One way of measuring wealth might be by looking for information on income, but this misses inherited or accumulated wealth; individuals could be wealthy without earning money. Moreover, New Zealand's taxation records do not make income clear. ${ }^{42}$ There are similar issues with expenditure. Some wealthy may not have spent freely, and

39 Jim McAloon, No Idle Rich: The Wealthy in Canterbury and Otago 1840-1914, (Dunedin, 2002).

40 McAloon, p.27.

${ }^{41}$ Of course, the selection of a specific figure is somewhat arbitrary. $f, 10,000$ has been chosen for two reasons. Firstly, $£, 10,000$ was a substantial level of wealth and so its employment limits this study to the truly wealthy. Further, the value of $£, 10,000$ facilitates comparison with McAloon, who used the same wealth threshold.

${ }^{42}$ Galt, p.2. 
some who spent freely may not have been wealthy. By measuring wealth that is held rather than that which is being accumulated or expended, we may reach a more robust understanding of wealth.

Other statistical information in the New Zealand record might be useful in locating wealth-holders. In particular, sheep returns in the mid-late nineteenth century list stock numbers. Similarly, the Return of Freebolders records the extent of property ownership. Such data however, are unable to say anything about the structure of wealth more generally, rather focussing on stockowners and landowners as subsections of the wealthy. The sheep returns, in particular, are self-selecting and exclusive of other forms of wealth. As we shall see, the Wairarapa wealthy were almost exclusively farmers, but land and stock do not give an entirely accurate indication of wealth.

End-of-life wealth, as recorded in probate records, gives the best indication of wealth. ${ }^{43}$ Changes in the taxation of inherited wealth in 1876 meant that estates were taxed in a way proportional to their entire value, rather than separate taxation for three forms of inheritance: succession, legacy and residuary — that is, property, money and that which was left over. ${ }^{44}$ The new stamp duties meant that total value of estates was thereafter recorded in testamentary registers, creating a useful record for the historian of wealth.

By measuring end-of-life wealth, probates favour those who accumulated fortunes, rather than spent them. While it is true that this leaves out those who may have accumulated and spent fortunes within one life time, McAloon has suggested that this bias can be considered a strength of probates: 'Selection by wealth at death incorporated the ultimate measure of financial achievement: not only the accumulation of wealth, but the keeping of it.' Stephanie Wyse, in her research on urban women's economic opportunity, has argued that 'one measure of an individual's success is the ability to earn and keep wealth; the loss of earned wealth may imply a high level of debt incurred, or even

\footnotetext{
43 As a result, probate files are a popular source in histories of wealth and the wealthy. In New Zealand, Margaret Galt has made most effective use of them: Margaret Galt, 'Wealth and Income in New Zealand, c.1870-c.1939', PhD Thesis, Victoria University of Wellington, 1985.

${ }^{44}$ For a discussion of the history of inheritance taxes in New Zealand see Michael Littlewood, 'The History of Death Duties and Gift Duty in New Zealand', The Journal of Taxation Law and Policy, vol. 18, no. 1, 2012, pp.66-103.
} 
carelessness. ${ }^{45}$ In such a way, the restriction of probates to those who were wealthy at the end of their lives acts not so much as a limitation as it does a means of testing for economic success.

Figure 2: Distribution of Estate Values in New Zealand, 1893-1910

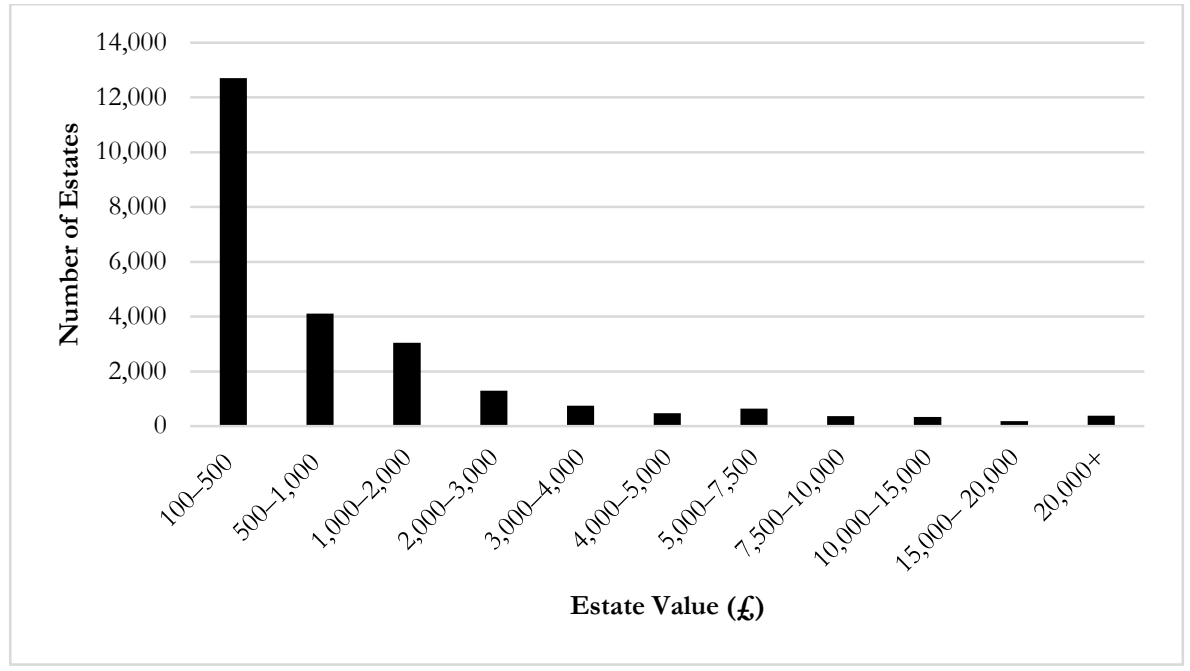

Probate records, then, allow us to identify wealth-holders but one important question is just how wealthy an estate of $£ 10,000$ made an individual between 1876 and 1913. While the simplest answer is to note that $£ 10,000$ is worth approximately $\$ 2,000,000$ (NZD) today, such numbers do not tell anywhere near the whole story. ${ }^{46}$ Wealth can be considered a relative quantity; what matters is not the amount of currency that belongs to an individual but the magnitude by which an individual's fortune outstrips their neighbour's. Between the years 1893 (when the data become available) and 1903, Galt estimates the average wealth of estates fluctuated between approximately $£ 290$ and $£, 550 .{ }^{47}$ Galt's numbers indicate that the Wairarapa wealthy were somewhere between eighteen and thirty-five times wealthier than the average New Zealand testator around the end of the

\footnotetext{
45 Stephanie Wyse, 'Gender, Wealth and Margins of Empire: Women's Economic Opportunity in New Zealand Cities, c.1890-1950’, PhD Thesis, King’s College, London, 2008, p.67.

${ }^{46}$ This figure has been calculated using the Reserve Bank of New Zealand's 'Inflation Calculator', accessed at www.rbnz.govt.nz on 21 May 2015.

47 Galt, pp.10-11. Estimating wealth is inexact and, as Galt notes, the age structure of death distorts the numbers a little. There is little doubt, however, that by relative terms, those that left $f 10,000$ were very well off.
} 
nineteenth century. ${ }^{48}$ Another measure of wealth is exclusivity-just how common it was to leave $£ 10,000$ or more. Here, data from the Official New Zealand Yearbook proves useful. Between 1893 and 1910 in New Zealand, the Yearbook records 142,430 adult deaths. ${ }^{49}$ Figure 2 shows that very few (only 913, $0.6 \%$ of all testators) left $£ 10,000$ or more. The Wairarapa wealthy, then, were uncommonly rich-they were an exclusive minority with much more money than their neighbours.

Probate records are the most complete systematic source available, but they are not without their problems. Probates tend to be biased towards the elderly because the longer individuals live, the more likely they are to leave large estates. Figure 3, created from data from the 1913 Yearbook makes this bias clear-the average wealth of those who lived to old age was far greater than that of those who died young. While the relationship is more than simple causality — wealth may well have played some role in allowing for longevitythe young rich are probably underrepresented in this study. It is impossible to know exactly how the data is distorted, but the Wairarapa cohort is clearly made up of predominantly older people: the average age at death of the wealthy testators under study here was approximately sixty-nine, right in the middle of the wealthiest age bracket in Figure 3.

The during-lifetime bequest of property is another complicating factor. Lifetime gifts of property, known as inter vivos gifts, were only taxed if they were made shortly before death. This practice, if it was common, could artificially lower a testator's value, reducing the record's accuracy. McAloon and Wyse, however, both argue that inter vivos gift giving was quite rare. ${ }^{50}$ The evidence from this study itself further supports this claim. In only a very few cases did testators imply that any before-death division of property had taken place.

\footnotetext{
48 Unfortunately, it is impossible to avoid the use of national statistics here-there is simply no way of comparing the wealth of testators in Wairarapa with average wealth in the region.

49 Data has been compiled from the 'Private Wealth' section of Yearbooks between 1893 and 1910. 'Private Wealth', Official New Zealand Yearbook, 1913. This data has been used to create Figure 2.

${ }^{50}$ Wyse, p.87 \& McAloon, p.15.
} 
Figure 3: Wealth by Age Bracket, $1912^{51}$

$\begin{array}{ccc}\begin{array}{c}\text { Age in } \\ \text { years }\end{array} & \begin{array}{c}\text { Number of } \\ \text { estates } \\ \text { certified }\end{array} & \begin{array}{c}\text { Average Wealth } \\ \text { per person dying } \\ \text { (decimalised } \\ \text { pounds) }\end{array} \\ \mathbf{0 - 1 9} & 89 & 0.93 \\ \mathbf{2 0 - 3 9} & 1468 & 143.36 \\ \mathbf{4 0 - 5 9} & 2960 & 661.53 \\ \mathbf{6 0 - 7 9} & 5517 & 1,257.37 \\ \mathbf{8 0 +} & 1488 & 1,072.68\end{array}$

Lastly, the reliability of property valuations might be questioned. Galt argues that because estate tax was paid in proportion to an estate's total value, 'there was considerable pressure on the administrators to ensure the valuation was conservative. ${ }^{52}$ One of the ways of doing this was by valuing real property (that is land and buildings) according to government valuation rather than the usually higher market valuation. ${ }^{53}$ Household effects, regardless of their market value, were usually listed at $£ 15 .^{54}$ Galt suggests that low estate tax and harsh legal punishments (along with social repercussions) meant that significant tax evasion (and therefore distortion of the record) would have been rare. ${ }^{55}$ Although this is a small sample size with which to analyse the prevalence of tax avoidance on death duties, there does not appear to be any grouping at the upper limit of tax brackets among the testators studied here. ${ }^{56}$

Regardless of these problems, it is less important that the wealth figures are accurate than it is they are unbiased. A study that uses end-of-life wealth (as all systematic studies of wealth in New Zealand have) struggles to extrapolate and say something precise about wealth figures during life. As Galt notes, some assets—such as life insurance policies—are

\footnotetext{
51 'Private Wealth', Official New Zealand Yearbook, 1913.

52 Galt, p.6.

53 ibid.

54 ibid.

55 Galt, p.7.

56 This analysis, of course, assumes that estates valued deliberately low would be doctored only enough to fall just within a tax threshold—-more extensive distortion remains possible, although unlikely.
} 
impossible to own during a lifetime. ${ }^{57}$ The possibility of their inclusions in estate valuations is a constant threat to the accuracy of figures. However, as long as an inaccuracy does not exclude any type of individual or group, it is less of a problem; while the data might be altered, it remains undistorted. ${ }^{58}$

Whatever the shortcomings of probates as a record of wealth, their biggest strength is the singularity of their existence-there is simply nothing else. Probate sources allow a systematic approach, one that avoids the tyranny of the traditional record in order to say something about all the wealthy.

\section{Overview}

Throughout, this thesis compares the rich in Wairarapa with those in Canterbury and Otago in order to develop the understanding of wealthy identity in New Zealand. Although the Wairarapa rich differed from those in Canterbury and Otago in several ways, these comparisons ultimately extend McAloon's conclusion - that the rich in New Zealand were hard-working capitalists_-into the North Island.

This thesis is first occupied by the quantitative aspects of wealth in Wairarapa. Chapter one focuses on the extent and distribution of wealth among the wealthy in Wairarapa as well as surveying their accumulation strategies, proposing a categorisation of the rich. Chapter one also explores the origins of the testators demonstrating that the wealthy tended to come from the lower middle classes in Britain.

Chapter two uses testamentary practices to analyse the wealthy in private. Here, the rich demonstrate that property was divided according to necessity-the realities of economic survival under capitalism dictated their testamentary decisions. Specifically, the wealthy used the will as a means of organising their family's long-term future, and tended to promote familial equality through partible division of their estates.

Chapter three is concerned with the role of the wealthy in their community. It analyses the different ways that self-interest combined with various ideas about

${ }^{57}$ Galt, p.43.

${ }^{58}$ Rubinstein, W. D. Men Of Property: The Very Wealtby in Britain Since the Industrial Revolution, (New Jersey, 1981) p.14. 
'community' in order to shape attitudes and behaviour. Chapter three demonstrates that in public, the wealthy began to re-define status, becoming less involved in community affairs and charitable works than their middle-class origins would have suggested.

Ultimately, the wealthy were caught between two worlds: that which they had left and that to which they had come. The public and private lives of the wealthy reflected this tension. Whereas in a new world-one with a middle class but no upper-wealthy capitalists no longer needed to justify their position in opposition to a gentry, the realities of economic life that had governed the middle-class family in Britain were just as real in New Zealand. In private, then, the wealthy reflected their origins-sharing their wealth and utilising the family's labour. 



\section{Chapter One: An Anatomy of Wairarapa Wealth}

This chapter establishes some quantifiable aspects of wealth: the accumulation strategies followed by the Wairarapa wealthy, their socioeconomic and geographic origins, and the extent and distribution of wealth among the rich. First, this chapter identifies farming as the dominant source of the wealthy's riches and makes a distinction between the extensive practices of early pastoralists and the more focused approach of intensive farmers. Both groups of farmers were later joined by a few who made their wealth through non-farming enterprise. Second, this chapter locates the wealthy's origins in the British middle classes, demonstrating that the Wairarapa rich had improved their position through emigration. Last, this chapter looks at the money itself, analysing the extent and variation of Wairarapa wealth and demonstrating that even among the rich, wealth was unevenly distributed.

\section{The Structure of Wealth}

An examination of the testamentary registers for the Wellington region between 1876 and 1913 produced 352 individuals who left estates worth $f_{10,000}$ or more. By looking at other biographical information such as obituaries and biographies, those from Wairarapa were isolated from elsewhere in the wider Wellington Region. All told, the process produced sixty-five individuals, a cohort of wealthy Wairarapa testators. They are listed in Figure 4.

Wealth in Wairarapa was overwhelmingly agricultural or pastoral but small groups of individuals were involved in the extraction and service industries. Whereas McAloon's 1,042-person cohort allowed him to treat 'agricultural and pastoral' wealth separately to 'urban wealth', the much smaller cohort of sixty-five (as well as Wairarapa's lack of a major urban centre) makes this separation less useful in this case. ${ }^{1}$ Here, a much more limited occupational categorisation is proposed.

\footnotetext{
${ }^{1}$ McAloon, p.15.
} 
Figure 4: The Wealthy Wairarapa Testators

\begin{tabular}{|c|c|c|c|c|}
\hline & Occupation & Wealth & Death & Arrival in NZ \\
\hline Andersen, Anders & Intensive farmer & $£ 15,646$ & 1907 & 1869 \\
\hline Andrew, John Chapman & Pastoralist & $£ 109,786$ & 1907 & 1856 \\
\hline Armstrong, James & Pastoralist & $£ 33,739$ & 1880 & 1876 \\
\hline Beetham, Richmond & Magistrate & $£ 17,730$ & 1912 & 1855 \\
\hline Bidwill, Charles Robert & Pastoralist & $£ 29,971$ & 1884 & 1843 \\
\hline Bidwill, Charles Robert & Pastoralist & $£, 36,381$ & 1902 & $2^{\text {nd }}$ Gen \\
\hline Booth, William & Sawmiller & $f^{88,208}$ & 1903 & 1872 \\
\hline Brown, Thomas & Intensive Farmer & $\AA_{10,100}$ & 1910 & $2^{\text {nd }}$ Gen \\
\hline Buick, William Butler & Intensive Farmer & $f^{34,931}$ & 1903 & $2^{\text {nd }}$ Gen \\
\hline Cameron, John & Pastoralist & $£ 12,231$ & 1900 & 1840 \\
\hline Card, Hanna & Hotelkeeper & $f^{28,179}$ & 1912 & 1870 \\
\hline Card, John & Hotelkeeper & $£ 20,000$ & 1909 & 1849 \\
\hline Cockburn, Robert & Pastoralist & $f^{5}, 551$ & 1906 & 1852 \\
\hline Collins, Caroline & Undefined & $f_{11,881}$ & 1894 & 1842 \\
\hline Colquhoun, John & Intensive Farmer & $f^{25,675}$ & 1913 & 1875 \\
\hline Cotter, Pierce & Intensive Farmer & $f_{1} 18,116$ & 1894 & Unknown \\
\hline Cotter, John & Intensive Farmer & $f^{24,158}$ & 1911 & $2^{\text {nd }}$ Gen \\
\hline Dakin, Charles & Intensive Farmer & $£ 13,452$ & 1895 & 1856 \\
\hline Donald, James & Intensive Farmer & $f_{1} 18,892$ & 1899 & 1855 \\
\hline Eglinton, Henry & Pastoralist & $£ 24,400$ & 1904 & 1841 \\
\hline Gawith, Charles Frederick & Solicitor & $f^{22,876}$ & 1911 & $2^{\text {nd }}$ Gen \\
\hline Gray, Farquhar & Intensive Farmer & $£ 16,145$ & 1894 & 1865 \\
\hline Groves, John & Farmer & $f^{24,203}$ & 1905 & 1854 \\
\hline Hales, Frederick William & Farmer & $£ 19,921$ & 1911 & $2^{\text {nd }}$ Gen \\
\hline Harris, Charles & Pastoralist & $f^{8} 89,450$ & 1913 & 1840 \\
\hline Holmes, Henry & Intensive Farmer & $f^{6} 63,959$ & 1911 & 1874 \\
\hline Hume, Peter & Pastoralist & $f^{32,441}$ & 1892 & 1840 \\
\hline Jackson, Henry Humphrey & Intensive Farmer & $f_{19,759}$ & 1905 & 1840 \\
\hline Judd, John & Intensive Farmer & $£ 14,265$ & 1911 & 1840 \\
\hline Judd, William & Intensive Farmer & $£ 12,259$ & 1906 & $2^{\text {nd }}$ Gen \\
\hline Kempton, Thomas & Intensive Farmer & $f^{25,268}$ & 1910 & 1840 \\
\hline Lowes, William & Storekeeper & $£ 11,635$ & 1901 & 1865 \\
\hline Lucena, William Lancaster & Farmer & $£, 56,017$ & 1897 & 1852 \\
\hline Luxford, George Henry & Intensive Farmer & $£ 33,880$ & 1905 & 1840 \\
\hline Mace, George Walter & Pastoralist & $f, 43,401$ & 1907 & 1843 \\
\hline Martin, John & Pastoralist & $f_{92,358}$ & 1892 & 1841 \\
\hline Matthews, Jacob & Intensive Farmer & $f^{20,719}$ & 1908 & 1856 \\
\hline Maunsell, Edward Swartz & Intensive Farmer & $£ 10,306$ & 1908 & $2^{\text {nd }}$ Gen \\
\hline Maunsell, Robert & Farmer & $f, 101,422$ & 1908 & $2^{\text {nd }}$ Gen \\
\hline McLaren, Donald & Pastoralist & $£ 10,309$ & 1893 & 1857 \\
\hline McMaster, Angus & Pastoralist & $£ 10,539$ & 1888 & 1841 \\
\hline Meredith, Edwin & Pastoralist & $\AA^{4} 44,329$ & 1907 & 1851 \\
\hline Monckton, Frederick & Intensive Farmer & $\AA_{14,857}$ & 1909 & 1883 \\
\hline Morris, John & Intensive Farmer & $f^{22,811}$ & 1906 & 1866 \\
\hline Morrison, John & Farmer & $f^{39,845}$ & 1889 & 1842 \\
\hline Nicols, William & Farmer & $£ 14,511$ & 1890 & Unknown \\
\hline Oates, Joseph & Intensive Farmer & $£ 14,989$ & 1912 & 1856 \\
\hline Pattinson, John & Intensive Farmer & $£, 30,149$ & 1910 & 1842 \\
\hline Perry, Bennett Pascoe & Farmer & $£, 33,231$ & 1894 & 1841 \\
\hline Pharazyn, Edward & Lawyer & $f_{107,013}$ & 1890 & 1841 \\
\hline Pharazyn, Charles & Pastoralist & $f_{151,260}$ & 1903 & 1841 \\
\hline Price, Thomas & Sawmiller & $\AA^{24,750}$ & 1906 & 1842 \\
\hline Rayner, John & Intensive Farmer & $f_{17,432}$ & 1903 & 1853 \\
\hline Renall, Alfred Williams & Intensive Farmer & $\AA^{26,601}$ & 1902 & 1840 \\
\hline Reynolds, John & Intensive Farmer & $£, 14,963$ & 1906 & 1854 \\
\hline Riddiford, Harriot & Undefined & $£, 50,101$ & 1891 & 1840 \\
\hline Riddiford, Edward Joshua & Pastoralist & $£, 584,622$ & 1911 & $2^{\text {nd }}$ Gen \\
\hline Russell, John Purvis & Pastoralist & $f^{4}, 6,632$ & 1906 & 1852 \\
\hline Strang, James & Pastoralist & $£, 12,825$ & 1895 & 1851 \\
\hline Smith, William & Farmer & $£, 19,776$ & 1903 & Unknown \\
\hline Sutherland, Alexander Robert & Pastoralist & $f^{4} 40,767$ & 1877 & 1840 \\
\hline Udy, Hart & Sawmiller & $£ 23,958$ & 1905 & 1840 \\
\hline Vallance, Charles Augustus & Pastoralist & $£ 19,123$ & 1882 & 1840 \\
\hline Wrigley, James & Intensive Farmer & $£ 13,534$ & 1904 & 1852 \\
\hline Yule, Isabella & Undefined & $£ 11,819$ & 1890 & Unknown \\
\hline
\end{tabular}


Figure 5: Occupational Breakdown of the Wairarapa Wealthy

\begin{tabular}{|rcc} 
& Number & $\%$ \\
Farming & 53 & 81.5 \\
Extraction & 3 & 4.6 \\
\hline Hotels/Storekeepers & 3 & 4.6 \\
Professional & 3 & 4.6 \\
Undefined & 3 & 4.6
\end{tabular}

Occupational categorisation has a degree of arbitrariness, especially considering the tendency for wealthy individuals to have various occupations and interests. John Chapman Andrew (d.1907, f109,786), for example, was an Anglican clergyman, a politician andfor a time-the Head of Nelson College. In cases like Andrew's it can be difficult to assign primacy to one occupation. Miles Fairburn has discussed the difficulties of reading the occupational labels chosen by colonists-demonstrating the ways in which labels could disguise multitudinous identities. 'As occupational relationships in nineteenthcentury New Zealand were so obscure,' Fairburn concluded, 'my inclination is to stop looking at the society occupationally. ${ }^{2}$ Certainly, occupational titles do not always match comfortably with 'actual' occupation, but Fairburn's warning is more relevant in cases where individuals appear only once in the record. For the majority of the wealthy in this study, further biographical information has been sought (and found available) in order to overcome some of these difficulties. In Figure 5, an individual's biggest-earning occupation has been taken as their 'primary' occupation. Sometimes, this is obvious; an individual may have only had one occupation that was clearly designed to bring about financial success. This is certainly useful in the case of Andrew, whose various nonfarming ventures were public roles and not intended as money-making ventures.

Figure 5 demonstrates that farming fortunes made up more than two thirds of estates probated by the wealthy $(81.5 \%)$, marking Wairarapa as a distinctly rural area. In

\footnotetext{
${ }^{2}$ Miles Fairburn, 'Social Mobility and Opportunity in Nineteenth Century New Zealand', New Zealand Journal of History, vol. 13, no. 1, 1979, p.54.
} 
Canterbury (56.5\%) and Otago (40.7\%) farming made up a significantly smaller proportion of estates than in Wairarapa. In the South Island, fortunes made in farming competed with those made by merchants, financiers, manufacturers and professionals. ${ }^{3}$ In the Lower North Island, many of the urban wealthy would have been found in Wellington, separated from Wairarapa by the Rimutaka and Tararua ranges.

Wairarapa might have been dominated by farmers, but by grouping all forms of landed wealth together there is the potential to homogenise disparate groups. One major group, 'the pastoralists', arrived early (pre-crown purchase), organised illegal leases with Māori and developed their leaseholds into profitable pastoral runs, ultimately having their position legitimised by the crown after McLean's purchases. These pastoralists were quickly joined by a second group of 'intensive farmers', who took up land on the Taratahi plain and around Lakes Wairarapa and Onoke. These intensive farmers were less wedded to sheep; several created early dairy farms and later-arrivals tried their hand at mixed farming.

In many cases, it is impossible to separate 'pastoralists' and 'intensive farmers' with certainty. Some individuals shared characteristics of both groups and others left insufficient biographical information to decide either way. Broadly, however, farmers were either extensive pastoralists or more intensive, small-scale farmers. A count of those who can be positively identified gives twenty pastoralists $(37.7 \%$ of farmers, $30.8 \%$ of total) and twenty-five intensive farmers $(47.2 \%$ of farmers, $38.5 \%$ of total). As well as differences in practices, there were substantial differences in wealth; pastoralists left on average $£ 73,878$ while intensive farmers left $£ 21,315$.

\section{The Pastoralists}

The wealthy Wairarapa pastoralists tended to arrive in the area early, arrange leases on the East Coast or Lower Plains with local iwi and gradually shift from extensive grazing to more intensive practices.

\footnotetext{
${ }^{3}$ McAloon, p.20.
} 
There exists a small body of literature on the early stages of pastoralism in the Lower North Island. R. D. Hill was the earliest, focussing on the economic and social dynamics of establishment in his 1962 thesis. ${ }^{4}$ Brad Patterson has recently revisited Hill's thesis in his ongoing research on the dynamics of colonial pastoralism. ${ }^{5}$ Patterson has proposed several 'operational characteristics' of 'Establishment Pastoralism': the relative simplicity of establishment (acquire run, stock run), the crudeness of husbandry, and the impact of difficult environmental conditions, which limited early progress. ${ }^{6}$ Patterson concludes that the durability of pastoralism was a product of its profitability; ultimately even New Zealand Company officials, whose position had been to oppose pastoralism, were won over and several established their own sheep runs.

On a national level, there are other studies of colonial pastoralism. John Weaver has examined the 'social construction of property', tracing the 'chaotic' transition from lease arrangements with Māori into crown attempts at purchase and the ratification of squatters' lands-placing the New Zealand construction of property in an imperial context. ${ }^{7}$ Robert Peden has identified operational characteristics of pastoralism in the South Island, using Mt. Peel station as a case study for regional trends. ${ }^{8}$ In 2011, Tom Brooking and Eric Pawson published Seeds of Empire, a collection of essays on the introduction of exotic grasses to New Zealand during the colonial era. ${ }^{9}$ Although wide in scope, Seeds of Empire is of most relevance to this study when examining the role of exotic grasses in facilitating more intensive practices among farmers. ${ }^{10}$

\footnotetext{
4 R.D. Hill, 'The Land and the Squatter: Wairarapa 1843-1853', M.A. Thesis, Victoria University of Wellington, 1962.

5 Patterson, pp.3-14.

${ }^{6}$ Patterson, pp.10-14 The establishment phase is defined as that which occurred between 1840 and 1855. Patterson divides the development of Pastoralism into three phases: Establishment, 1840-1855; Expansion, 1855-late 1860s; and thereafter a period of more intensive farming. Only Patterson's work on the 'Establishment' phase has been heretofore published.

${ }^{7}$ John C. Weaver, 'Frontiers into Assets: The Social Construction of Property in New Zealand, 1840-65' The Journal of Imperial and Commonwealth History, vol. 27, no. 3, 1999

8 Robert Peden, Making Sheep Country: Mt Peel Station and the Transformation of the tussock lands, (Auckland, 2011).

9 Tom Brooking \& Eric Pawson (ed.) Seeds of Empire: The Environmental Transformation of New Zealand, (London, 2011).

${ }^{10}$ In particular, Peter Holland, Jim Williams \& Vaughan Wood, 'Learning about the Environment in Early Colonial New Zealand' pp.34-51 and Robert Peden, 'Pastoralism and the Transformation of the Open Grasslands' pp.51-73 in Seeds of Empire.
} 
Existing research is focused on pastoralism more than on pastoralists and, as such, there are important differences between this study and others. Whereas Patterson and Hill are interested in all who established early runs, here we are solely concerned with those who were still in the region at their death, and who left an estate valued at $£ 10,000$ or more. These two categories turn out to be essentially synonymous; those that arrived early, established extensive sheep runs and were still there or thereabouts at the time of their death tended to be wealthy enough for inclusion in this study.

Despite the correlation of continual residence and success, pastoral wealth was much more than a simple waiting game. For various reasons, many failed to stick at it. Indeed, a number of those who appear in other accounts of early pastoralism were gone before 1876. The first and most famous early pastoralists were the 'Wharekaka Catholics' - a group of five, four of whom were Roman Catholics of aristocratic descent. ${ }^{11}$ The group did not last long, leaving the district in search of lower rents after four years. Others came and went, too. R. D. Wallace, his brother Ellerslie and Charles Vallance took up Tauanui station in 1844, selling in 1845 in the face of growing competition. ${ }^{12}$ Further north, Henry Tiffen and James Northwood took up Ahiaruhe in 1845 with 758 merinos before leaving for Hawke's Bay four years later. ${ }^{13}$ The occupation of land on Wairarapa's pastoral frontier was in a constant state of flux; pastoralists were coming and going continuously.

Many pastoralists arrived early and arranged leases with Māori. ${ }^{14}$ Charles Bidwill (d.1884, $\left.f^{29}, 971\right)$, who arrived in the basin in company with the Wharekaka Catholics, came to New Zealand in 1843, looking for land for his stock; the beginnings of a flock

\footnotetext{
${ }^{11}$ So-called by Bagnall, p.51. The aristocrats were Frederick Weld, Charles Clifford, William Vavasour and Henry Petre. Charles Robert Bidwill was the fifth member. The prominence of the Wharekaka Catholics in early histories of pastoralism is partly a product of their early arrival, but the survival of Frederick Weld's personal papers is also important. The survival of Weld's record is in turn a product of his later career as Premier (1864-1865).

${ }^{12}$ Bagnall, p.57 Vallance, who was managing partner for the Wallace brothers, went on to farm his own run at Kahumingi, dying in 1882 with $f, 19,123$.

${ }^{13}$ Ian McGibbon, 'Tiffen, Henry Stokes', Dictionary of New Zealand Biography. Te Ara - the Encyclopedia of New Zealand, available at http://www.teara.govt.nz, updated 30 Oct 2012.

${ }^{14}$ Other pastoralists might have been included had they not died too soon. Most notably Richard Barton who died at White Rock station in 1866. Barton's son William would have also made enough money for inclusion had he not died too late. William Barton died in 1938.
} 
that he had brought with him across the Tasman. ${ }^{15}$ He arranged a lease of $£ 12$ with Ngāti Kahungunu leader Te Manihera Te Rangi-taka-i-waho in 1844 at Pihautea, on the eastern shore of Lake Wairarapa. ${ }^{16}$ Bidwill and the rest of the party apparently met Thomas Purvis Russell while travelling to take up their run. ${ }^{17}$ Russell, Bagnall speculates, was on his way to Palliser Bay where he took up Whangaimoana shortly thereafter. Russell was later joined by four of his brothers. One brother, John Purvis Russell, died in 1906 with £46,632. ${ }^{18}$ Elsewhere, Angus McMaster (d.1888, £10,539) arranged a lease with Te Hiko Piata Tama-i-hokoia at Tuhitarata in 1843, becoming known in Wairarapa as 'Hiko's Pakeha. $^{19}$

While early arrival was important and conferred the advantages of (relatively) open run selection, early monopolisation, and the inherent value of a scarce product, successful pastoralists continued to arrive after the Crown purchases in 1853. After arriving in 1855, William Beetham, a Surrey portrait artist of minor fame, helped his sons George, Richmond (d.1912, f,17,730) and William set up a run in 1856. Having suffered through a shortage of capital, Brancepeth, as the Beethams named their run, flourished after securing investment from T.C. Williams, a wealthy landowner and the son of the missionary Henry Williams. ${ }^{20}$ At its height, Brancepeth covered almost 75,000 acres. Edwin Meredith (d.1907, $£ 44,329)$ was another who arrived in the 1850 s and became rich as a pastoralist. In 1854, Meredith obtained the freehold of a 15,000-acre property in Whareama named Orui, having previously given up 80,000 acres in Otago after 'land troubles'. ${ }^{21}$ Even into the 1860s, extensive holdings were possible. Robert Cockburn (d.1906, f,52,551) left

\footnotetext{
15 Bidwill came to New Zealand after two years in Australia. McAloon and Patterson have both noted the frequency of this path. Bidwill is not alone in Wairarapa in this regard, either. Many of the wealthy arrived in the region from other pastoral areas (most notably Australia), and many who left found land elsewhere.

16 Patterson has data on average leases in pre-purchase Wairarapa, demonstrating that average leases grew from approximately $£_{17}$ in 1844 to $£^{44}$ in 1852 . Patterson, p.11.

17 Bagnall, p.52.

18 Bagnall, p.66. On several occasions, the first generation of pastoralists died too early, but their sons met the requirements for inclusion. Charles Pharazyn accompanied Henry Tiffen on his 1845 journey to Ahiaruhe, taking up a station, Whatarangi, at Palliser Bay. Pharazyn's son Charles Jr. committed suicide in London in 1903. His estate was sworn under £151,260.

19 Angela Ballara and Mita Carter, 'Te Hiko Piata Tama-i-hikoia', The Dictionary of New Zealand Biography, Te Ara_the Encyclopedia of New Zealand, available at http://www.teara.govt.nz, updated 28 August 2014.

20 T.C. Williams had recently married William Beetham's daughter Annie.

21 'In Memoriam', Wairarapa Daily Times, 5 March 1907, p.5 Meredith's first run was absorbed by the Otago Association while he was in Tasmania. Meredith had been travelling up the East Coast with 120 cattle in search of land in Hawke's Bay when he heard that McLean had secured the Whareama purchase.
} 
Hawke's Bay with his brother Alexander to take up a 10,000-acre run in lower Manaia, receiving complete control shortly thereafter. ${ }^{22}$ While early arrival was important, many successful runs were taken up post-purchase.

Following the Crown's purchases in Wairarapa, the pastoralists were no longer subject to the will of lessors, and because their position was now less precarious, they began to invest in improvements. ${ }^{23}$ Bidwill built his first homestead in 1846 after early huts had been washed out in flood. His new house was $12^{\prime} \times 24^{\prime}$ and made from handsawn timber. ${ }^{24}$ Angus McMaster's whare was only 12' $\times 13,{ }^{25}$ Henry Eglinton (d.1904, $£^{24,400)}$ began life on his Palliser Bay run in a simple mud hut. ${ }^{26}$ In flurries of activity, the second half of the nineteenth century saw pastoralists improve their living conditionsoften going from a simple dwelling to considerable comfort abruptly. In 1876, Bidwill, his wife Catherine and their eldest son went on a long trip to England, during which period they had a twenty-room homestead erected on the site of their timber dwelling upon which 'borer had made such ravages. ${ }^{27}$ The same year, John Purvis Russell set out a sixacre block and had a large homestead known as 'The Castle' built. ${ }^{28}$

Pastoral techniques were also improving-as stocking rates increased and profit margins dwindled, making money was no longer as simple as stocking the land. Peden has highlighted the ways in which early South Island pastoralists refined their techniques, paving the way for more intensive forms of farming and similar trends can be identified in the Lower North Island. Early on, Charles Bidwill had made little improvement to his land. Charles's son William Bidwill wrote in a biography of his father, 'very little cultivation was done, although Bidwill possessed a swing plough with which he put in a small quantity of wheat, and he also grew a few potatoes for his own use. ${ }^{29}$ Following the crown purchase of the Pihautea homestead block in 1858, however, Bidwill set about

\footnotetext{
22 'The Passing of a Pioneer', Wairarapa Daily Times, 12 February 1906, p.5.

23 This worked both ways. The crown purchases enabled the pastoralists the security to improve their land, but the process of improvement in turn improved the pastoralists' claim to the land. Weaver, p.22.

${ }^{24}$ Paul Goldsmith, The Bidwills, (Auckland, 2012) p.37.

25 'Pioneering Experiences', Dominion, 26 November 1910, p.18.

${ }^{26}$ C. J. Carle, A Gateway to Wairarapa, (Featherston, 1957), p.35.

${ }^{27}$ William Edward Bidwill, Bidwill of Pihautea: the life of Charles Robert Bidwill, (Christchurch, 1927) p.10.

28 Mary Boyd, 'Russell, Henry Robert', Te Ara - the Encyclopedia of New Zealand, available at http:/ /www.teara.govt.nz, updated 28 January 2014.

${ }^{29}$ Bidwill of Pihautea, p.10.
} 
improving his swampy waterside land, employing a team of men to dig drains with shovels. ${ }^{30}$ On the East Coast, John Andrew's Station was being cleared of fern, ploughed and planted with exotic grasses. A report in 1883 boasted that the run could now be stocked at six-seven sheep an acre, significant progress on earlier stocking rates. ${ }^{31}$ An 1867 letter from Angus McMaster to Donald McLean (who had begun to focus on purchasing property for himself) suggests that pastoralists were by this point much more interested in intensive farming:

You will be glad to hear that I received the sheep all right. But I must say I was rather disappointed in the size of them. They were certainly very fine but scarcely the size of my [illegible]. I think that it would be advisable for you to look into the matter and make a little alteration in the management of your stock. But when I have an opportunity of seeing yourself I will explain what I mean more fully... ${ }^{32}$

Whatever the particulars of McMaster's un-divulged advice, he had evidently progressed from earlier, extensive practice. ${ }^{33}$

Having arrived early and hurriedly acquired land, the pastoralists, then, had gradually evolved from crude forms of early farming to more efficient methods. In their progress towards focused practices, the pastoralists were gravitating towards those of another group of wealthy Wairarapa farmers: the 'intensive farmers'.

\section{Intensive Farmers}

The pastoralists' extensive sheep runs were quickly joined by much smaller (in size if not activity) operations. These intensive farmers grouped in the Wairarapa basin around the new towns: Greytown, Masterton, and Featherston. Intensive farmers were less wedded to sheep; several ran dairy herds and a (very) few planted crops.

\footnotetext{
30 Ibid.

${ }^{31}$ Bagnall, p.332.

32 Letter from Angus McMaster to Donald McLean, 25 April 1867, MS-Papers-0032-0439, Alexander Turnbull Library, Wellington, New Zealand.

${ }^{33}$ Associated with these shifts towards intensive farming were evolutions in employee structure. Where early runs required very few staff, by the end of the century pastoral runs were often home to many employees. John Martin (John E. Martin, The Forgotten Worker: The Rural Wage Earner in Nineteenth-Century New Zealand, (Wellington, Allen \& Unwin, 1990) has discussed the way in which large-scale pastoralist enterprise came to mirror the intensive practices of urban factories. Chapter three discusses the ways in which runholders 'managed' such large groups of employees through a paternalistic approach.
} 
Many smaller farmers who became rich had links to the Small Farms Association, the group which founded Masterton and Greytown. In 1853 Joseph Masters, a young cooper who arrived in Wellington from Derby via Van Diemen's Land, began agitating for a group of 'Working Men' to

Come forward and form a company or two, and take shares from $£ 10$ to $£ 25$, to purchase a good large block of land, form your own village centre. Skill and labour, with a little capital will do wonder; be united and you will be able to have towns and farms of your own. ${ }^{34}$

Masters saw the small farmers as being in direct competition with the squatters, writing

the land in Wairarapa is very anxiously sought after and purchased by the wealthy settler, though their colonial pride revolts at the very idea of Small Farms, which in the end will be to their advantage. ${ }^{35}$

While the race to settle the land in Wairarapa was competitive, Masters argued that Small Farmers would advantage everybody. After a series of meetings, the Association organised and were given a reserve of 25,000 acres by Governor Grey. Would-be small farmers could purchase a one-acre town section from the Association, and a forty-acre rural section directly from the government.

The Small Farms Association was created, as the Māori-leasehold economy was, out of the failings of the Port Nicholson settlement. Just as the lack of land for grazing drove pastoralists over the Rimutakas to establish leasehold runs with local Māori, a lack of work for potential farm labourers encouraged less-wealthy men to follow suit, and they began searching for alternatives. Bagnall argues that

[the Small Farmers] were escaping from a shortage of flat land and the press of forest-clad hills as well as from the injustices and frustrations imposed by New Zealand Company theory and practice. The concept of well-endowed capitalistlandowners who were to provide continuing employment to a labour-pool of sturdy but not too ambitious yeomanry had not quite worked out. ${ }^{36}$

Greytown and Masterton were set up as identical Small Farms settlements. Both townships consisted of 100 one-acre town sections, each of which being linked to a forty-

\footnotetext{
34 ‘Original Correspondence’, Wellington Independent, 12 March 1853, p.2.

35 'Original Correspondence', Wellington Independent, 24 December 1853, p.4.

36 Bagnall, p.137.
} 
acre suburban section. There were also 100-acre rural sections. The idea was for townspeople to live together in the town and work on their farms. The townspeople would require services, attracting others to the area and the towns would grow. ${ }^{37}$ Greytown was founded in 1854, becoming New Zealand's first inland (Pākehā) settlement and quickly growing to dominate the other Wairarapa towns. Masterton was also founded in 1854. Lagging behind Greytown initially, Masterton eventually became the region's de facto capital.

One Masterton settler, James Wrigley (d.1904, £,13,354), epitomised the Small Farms Association ideal. Wrigley was the son of a weaver and himself a bootmaker who arrived in Wellington in 1852. He acquired land in the original allocation of properties through the Association and opened a bootmakers in Masterton. His enterprise proved successful; in 1872, Wrigley was financially secure enough to open impressive new premises. ${ }^{38} \mathrm{He}$ devoted himself to the farm fulltime in 1879 at the age of fifty-four, running a dairy herd on his rural section. When Wrigley died in 1904, his original 100 acres had expanded and he had made money through subdivision, ultimately leaving 583 acres to each of his two sons.

Farquhar Gray (d.1894, £16,145) followed a similar trajectory to Wrigley. Having arrived in New Zealand in 1865, Gray moved to Masterton and opened a forge. He made and repaired agricultural implements as well as farming on the Taratahi plains. Like Wrigley, Gray shifted his attention to his farm young-Gray was forty-four when he devoted himself to his farming. Gray and Wrigley might be categorised as something other than farmers - certainly they appear to have made some of their money through their lives as storekeepers and artisans, servicing the agricultural and pastoral economy before taking a more active role within it. Wrigley and Gray are included as intensive farmers, rather than as bootmakers or blacksmiths not only because farming was probably their biggest earner but because their shift towards the farm signifies an aspirational approach to farming; when it became possible, both Wrigley and Gray chose to focus on their farms.

\footnotetext{
${ }^{37}$ This model closely resembled the New Zealand Company's original plan.

38 'Wairarapa', Wellington Independent, 7 December 1872, p.3.
} 
Small farms initially struggled and many were swallowed up, allowing some of the settlers to expand their original smallholdings into those supporting sheep. Very small farms were problematic in that they did not support large flocks, and with wool the only product suitable for export in the mid-nineteenth century, the small farmers struggled to get ahead. ${ }^{39}$ This meant that small farmers were dependent on crops (especially wheat) early on and, one surmises, were dependent on local markets, putting them in a precarious position. ${ }^{40}$ One of those involved right from the beginning-Henry Humphrey Jackson (d.1905, £19,759)-moved away from the small farm ideal in order to make it rich. Jackson was involved in the association from its inception, having arrived in New Zealand aboard the Cuba in 1840. Jackson accompanied Masters on a journey to locate a site for Masterton and negotiated with local Māori (Jackson spoke Te Reo). Jackson himself established a 400-acre farm but moved away from Small Farms ideals, expanding to 3,000 acres, turning to sheep and farming his property with his three sons.

Other small farmers turned to dairy. Raymond Hambly, in his valuable 1966 thesis 'Dairying in the Wairarapa', argues that dairying in the region was synonymous with small farming. According to Hambly, the difficulty of turning bush into arable land for agricultural purposes was too great - it delayed the vital first payday, making agriculture unfeasible. ${ }^{41}$ Further, because small farmers ran dairy herds independently, and were generally averse to the 'American-style' dairy industry, it was left to 'entrepreneurs to attempt to stimulate improvements in the local dairy industry'. ${ }^{42}$ True as this may be, these entrepreneurs are absent from this study_presumably because they were located outside Wairarapa. ${ }^{43}$

\footnotetext{
39 Robin Holmes \& Allan Farley, Dear Sister: Letters between a pioneer Wairarapa family and relatives in rural England, 1856-1883, Wairarapa Archive, 2006. Later on-as refrigeration became possible-meat became a valuable export product, giving farmers more options.

40 Bagnall, p.167-172

41 Raymond Hambly, 'Dairying in the Wairarapa: A Socio-economic Survey Interpreted in Terms of Historical Small Farm Settlement', MA Thesis, Victoria University of Wellington, 1966.

${ }^{42}$ Hambly, p.31 The American Principle is the system in which 'farmers who supplied the milk received as payment the whole of the return from the sale of the produce less the cost of manufacture and selling'.

${ }^{43}$ Hambly argues that the impetus for Wairarapa dairy farming came from outsiders. Hambly, p.32.
} 
One who bucked the trend was James Donald (d.1899, £18,892) who founded the Tarureka Butter factory near Featherston. A 1901 article in the Wairarapa Daily Times proclaimed:

The Tarureka Butter Factory, situated at Featherston, in South Wairarapa, is an institution, the sight of which is calculated to gladden the heart of the scientific dairyman, the commercial man whose interests are connected with the dairying industry, and indeed of any one who realises the vast and ever increasing importance of dairying in New Zealand. ${ }^{44}$

Having begun as a family enterprise, Donald opened the factory in 1888. Many worked in the production of butter and five hands worked on the farm, each of whom having an interest in the business. At its height, Tarureka produced 600 pounds of butter a day. ${ }^{45}$

Other intensive farmers arrived later but the rising price of land represented a significant barrier to starting out, and as such, these farmers tended to be better off to begin with. With less pressure on fast turnover, these late-comers were more inclined toward mixed farming. One of these was Anders Andersen (d.1907, $£ 15,646)$ who bought land at Woodside in 1880 for $£ 2,800$. Another was Frederick Monckton (d.1909,

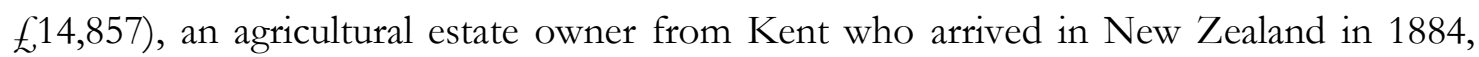
settling at Newstead to the north of Featherston - a 500-acre property. Monckton felt he had risked a lot to be there, and he was not willing to risk more, writing:

At present I have not a large place as I want to gain experience before risking my capital. I have only one man constant: a very steady working man who can do anything. I put by contract draining or bush felling to anyone who looks like work. ${ }^{46}$

Monckton was evidently feeling more confident two years later when he expanded by 1,000 acres, purchasing property in Tauherenikau. Monckton, like Andersen, ran crops as well as stock:

Hops, I think, can be grown almost anywhere in New Zealand, but I have no faith in their paying. Fruit I believe in and in the future it will be grown to a great extent.

\footnotetext{
44 ‘The Dairying Industry’, Wairarapa Daily Times, 10 April 1901, p.2.

45 ibid.

${ }^{46}$ Frederick Monckton to Mr. H. Hollindale, printed in Dorothea Joblin, The Colonial One: Lorna Monckton of Newstead, (Whitcombe \& Tombes, 1975) pp.40-43.
} 
The great drawback in many places-ours in particular-is the tremendous wind, but sheltered spots can be found. ${ }^{47}$

By this time, sheep were good for more than just their wool and Monckton was able to sell '50 beautiful lambs for 8 s. each..' to the buyer 'for a large freezing company in Wellington. ${ }^{48}$

The intensive farmers, then, were a diverse group. Although many had shared origins in the Small Farms Association, they found various ways of making their land profitable; some expanded and others were forced to work in other areas. Still others abandoned crops and sheep, favouring dairy. All intensive farmers, however, had a unified approach—-they all aimed to use their land efficiently.

\section{The Rest}

Although agricultural and pastoral pursuits dominated in Wairarapa, there remained other ways to get rich; nine testators left non-farming fortunes. Because non-farming forms of (primary) wealth accumulation were so uncommon in colonial Wairarapa, it is of little use to further isolate occupations within the category of 'the rest'. What is more, those that earned their fortune in the extraction, professional and service industries shared characteristics that warrant analysing them together. Non-farming wealth was often dependent on improvements and thus tended to be accumulated later on in the region's development than landed wealth. Further, because the occupations discussed here depended on substantial initial capital and/or population growth, they were usually undertaken later in life.

Early arrival was not important to the success of non-farmers in Wairarapa, and was often impossible. The frantic acquisition (whether by purchase or by lease) of early pastoral runs and relatively relaxed stocking conditions meant that the prospective pastoral elite needed to arrive early to succeed, but no such conditions existed for the rest. In fact, the opposite was true. Often, non-farming enterprise required the establishment of significant facilities before business could begin.

\footnotetext{
47 ibid.

48 ibid.
} 
Thomas Price (d.1906, £24,750), who eventually became a sawmiller, was one of those who arrived late. Price emigrated in 1842 and spent his first thirty years in New Zealand in Nelson, taking up small agricultural holdings as a young man. It was not until 1870 that Price left Nelson to become a general storekeeper in Carterton. Price spent five years establishing himself before he was ready to set up his sawmill, which he erected at Dalefield. He remained for twenty years in Carterton before opening a second mill in Newman. Price's Albion Sawmill was 'the largest in the Fourty-mile Bush. ${ }^{49}$ Later, he retired from his sawmills to run his associated timber yards in Petone.

Hart Udy (d.1905, f23,958), another who earned his fortune in timber, followed a similar trajectory. Like Price (whose father was a gardener), Udy had humble beginningshe worked from the age of nine with his father as a builder. Hart Udy and his father, also Hart, later went into milling together, first in Stokes Valley and later in Matarawa. Hart became sole proprietor of the Matarawa mill when his father retired in 1865. In 1893, Udy left the Matarawa mill, selling out to his business partner of almost fifteen years, a Mr. Gallon. Udy started another mill at Brownstown, also in the Forty Mile Bush.

It was not only the moderately successful who came late. William Booth, the last and most successful of the sawmillers, left a large fortune $(£, 88,208)$ but did not arrive in New Zealand until 1872. Booth's operation-which spanned several locations-employed more than forty people. In 1885 Booth produced 2,520,000 feet of timber-more than twice that produced by the next most productive mill. He noted that 'less than half our own machinery is at work at present', claiming that they were capable of producing $6,120,000$ feet of timber per annum when operating at capacity. ${ }^{50}$

The sawmillers were restricted by the difficulty of setting up in business. The inaccessibility of Wairarapa delayed operations. Booth, Price and Udy all sold their timber at their yards on the other side of the Rimutaka ranges-although there was a small local market in Wairarapa, they would have to wait for the valley to be opened up by railway to access the lucrative capital market. Even if they could get the timber to market, extracting

\footnotetext{
49 Cyclopedia Publishing Company, 'Price, Thomas', The Cyclopedia of New Zealand, Wellington Provincial Districts, (Wellington: Cyclopedia Company, Ltd., 1897) p.1005.

50 'List of Sawmills in the Wellington District. Return requested by Commr. Of Crown Lands 10 July 1885 listed in CCL 85,698' reproduced in Bagnall, p.463.
} 
and producing it was no mean feat. The first requirement was labour. Besides the men required to operate a mill, teams of bushmen lived together 'on-location' in camps logging trees and clearing the bush. ${ }^{51}$ In 1907, for instance, there were 411 sawmills in New Zealand and more than 7,000 people employed in the industry (whether in milling or logging) - approximately seventeen people per operation..$^{52}$ In Wairarapa, the 1885 return shows that in the milling operations alone (excluding many of those involved in logging) 246 were employed across sixteen different operations. ${ }^{53}$

Milling also required machinery, which posed further difficulties to the would-be miller. By the 1860s, steam-power engines superseded water mills. At his mill in Carterton, William Booth operated a forty-horsepower steam engine. The Cyclopedia wrote that it 'drives a complete plant of milling machinery, and there is also a detached planing mill with moulding shed, smithy, offices, etc.' At his other mill in Greytown, Booth operated a smaller twenty-horsepower engine. ${ }^{54}$ It was recorded that Price's sawmill is fitted with two travelling benches and twin saws, a ripping bench, breast bench, and planing machine, which are driven by a twenty-five horse-power engine. ${ }^{55}$ Price's mill was supplied with logs that travelled along a steel tramway, some travelling more than five miles along the apparatus. The physical equipment required to make milling profitable took time and capital to set up, making early establishment next to impossible for the wealthy Wairarapa sawmillers.

While the millers waited on access and improvements, other industries were dependent on clientele, which in turn required population growth. Among those operating in the service industry were the hotelkeepers. Hanna Card (née O’Shea, d.1912, £28,179) was born in Cork in 1840 and arrived in New Zealand in 1870. Once there she married John Card (d.1909, £20,000) and the couple kept their first hotel, The Pioneer on the West Coast of the South Island. The Cards later kept the Star and Garter in Wellington for three years in the early 1890 s before removing to Featherston, where they operated the

\footnotetext{
51 Nancy Swarbrick, 'Logging Native Forests', Te Ara - the Encyclopedia of New Zealand, available at http://www.teara.govt.nz, updated 13 July 2012.

52 ibid.

${ }^{53}$ Bagnall, p.463.

${ }^{54}$ Cyclopedia Publishing Company, 'Booth, W., And Company, The Cyclopedia of New Zealand, Taranaki Hawke's Bay \& Wellington Provincial Districts, (Christchurch, 1908), p.747.

55 'Price, Thomas', Cyclopedia, p.1005.
} 
Empire Hotel. Hotels like the Cards', in contrast with earlier bush-inns, depended on stable populations for business. ${ }^{56}$ The Empire, for example, boasted 'six or seven commercial-rooms, drawing-rooms and parlors' and frequently hosted community events. ${ }^{57}$ Clearly, operations like the Cards' would have to wait on urban development before entering business in the district.

While the Cards depended on urban development, others set up to service the rural economy. William Lowes (d.1901, f11,635) sold and repaired equipment for farmers. Lowes owned a saddlery in Wellington before opening a shop in Masterton in 1873. After a brief period farming at Te Ore Ore, he returned to business, setting up as an auctioneer and agent with Joseph Iorns. Although Lowes was less dependent on urban development than were the Cards at the Empire Hotel, a successful Masterton still benefited Lowe's business. There was little incentive for businesspeople like Lowes, already set up in Wellington, to leave a stable base of customers for an underdeveloped outpost on the colonial frontier.

Three Wairarapa professionals died between 1876 and 1913 and were worth more than $f_{10,000}$. Of these three, Charles Gawith (d.1911, $£^{22,876)}$ spent the most of his working life in the area. Gawith was born in Wellington in 1852 to Samuel Gawith, a carpenter for the New Zealand Company who later became a hotelkeeper. Charles served his articles in Wellington with Izard and Pharazyn and moved to Masterton in 1875 after being admitted as a barrister and solicitor. Gawith ran his Masterton firm for more than thirty years. The other two professionals, Richmond Beetham and Edward Pharazyn (d.1890, f107,013), spent substantially less time in the district. Richmond Beetham, who left his brothers at Brancepeth early on, pursued a career away from pastoralism as a magistrate before returning to Masterton. ${ }^{58}$ Very little is known about Edward Pharazyn other than that he was the son of the pastoralist C. J. Pharazyn. Edward obtained his law

\footnotetext{
${ }^{56}$ Bagnall offers a survey of frontier accommodation in Wairarapa in his chapter 'Over the Road to the Bush Inns', Bagnall, pp.108-121.

57 'Empire Hotel', Cyclopedia, Wellington, p.857.

58 'Obituary', Wairarapa Daily Times, 10 December 1912, p.5.
} 
degree in London and it appears that he died there, but his will mentions land in Wairarapa. ${ }^{59}$

The farming rich, then, were eventually joined by a small band of 'others' who pursued alternative accumulation strategies. Most commonly, these non-landed wealthy required substantial outlay to set up in business and so they tended to arrive in Wairarapa later than farmers. It is worth noting that not only did the non-agricultural rich fail (unsurprisingly) to loom large in what was an overwhelmingly agricultural setting, their fortunes were also slightly smaller. But for Booth's $£, 88,208$, all were situated comfortably in the $f^{20,000-30,000}$ bracket. Non-farming fortunes averaged $f^{38,261-m o r e ~ t h a n ~}$ $£, 5,000$ less than the average farming estate.

\section{Origins}

The wealthy Wairarapa testators came from the British lower and middle classes. Mostly, they emigrated from England, with a substantial portion of Scots and a small group of Irish.

Figure 6: Class Origins of the Wealthy Wairarapa Testators

$\begin{array}{rccc} & \text { Number } & \text { \% } & \text { South Island \% } \\ \text { Gentry } & 0 & 0 & 2.0 \\ \text { Upper-middle class } & 15 & 31.9 & 6.7 \\ \text { Lower-middle class } & 28 & 59.6 & 12.8 \\ \text { Wage-earning } & 4 & 8.5 & - \\ \text { Unknown } & 18 & - & - \\ \text { Total } & 65 & - & \end{array}$

\footnotetext{
59 'Local and General', Wellington Independent, 27 September 1866, p.4, Pharazyn Probate File, 1895, Series 6029, Accession W3265, No. 4580, ANZ/W.
} 
McAloon's framework for analysing the origins of the South Island wealthy has been adopted here in order to facilitate comparison. McAloon proposes the following categorisation based on a father's occupation or, if paternal information is unavailable, the testator's first colonial occupation:

The gentry includes all substantial landed families, including the titled. The upper middle class is working farmers with a freehold, manufacturers, merchants, and substantial professionals; the lower middle class includes self-employed artisans, smaller farmers, traders, farm managers, other professionals, and salaried clerical workers. The lower class are manual wage-earners. ${ }^{60}$

McAloon concluded that in Canterbury and Otago very few wealthy came from the upper classes. ${ }^{61}$ Figure 6 shows the Wairarapa results alongside McAloon's figures. ${ }^{62}$

Without exception, the Wairarapa wealthy testators did not come from the upper classes. Following the early departure from the region of the Wharekaka Catholics, only the fifth of their number, Charles Bidwill, has been claimed as a son of gentry. Bidwill's family is claimed in Burke's Colonial Gentry as having been 'seated for some generations' in Devon. ${ }^{63}$ Bagnall, while stopping short of the hagiographical Burke, describes Bidwill as 'a Devon man of education and some family background. ${ }^{64}$ The reality was different; Bidwill was born to Joseph Green Bidwill (listed by Burke as an officer in the Queen's guard), a Devon merchant who traded with his father as Joseph Bidwill and Son. Charles Bidwill began his career in the professions, studying medicine as a young man. One is inclined to agree with Paul Goldsmith, the family's most recent biographer, who argues, 'the Bidwills fell squarely amongst the professional classes of Exeter. ${ }^{65}$

Even armed with McAloon's criteria, it can be difficult to place individuals firmly inside categories. One reason for this is that other factors occasionally mitigated the effect

\footnotetext{
${ }^{60}$ McAloon, p.32.

${ }^{61}$ McAloon, p.32 \& p.55 Although in the South Island, the wealthiest pastoralists were slightly more likely to have upper-middle or upper-class origins than were other sections of the wealthy.

${ }^{62}$ South Island data created by joining two of McAloon's tables. McAloon, No Idle Rich, pp.32 \& 55 . It is difficult to know why upper middle class origins were more common in Wairarapa than in Canterbury and Otago. One explanation would be the increased opportunities in the South Island for small farming, hotelkeepers and other industries that required less initial capital. These opportunities may have helped more from the lower middle class and wage-earning class to make it rich.

${ }^{63}$ Bernard Burke, A Genealogical and Heraldic History of the Colonial Gentry, (London, 1891), p.345.

${ }^{64}$ Bagnall, p.52.

${ }^{65}$ Goldsmith, p.12.
} 
of parents' social position. The case of John Martin (d.1892, $, 92,358)$ serves to illustrate these difficulties. ${ }^{66}$ Martin was born in Moneymore in present day Northern Ireland, the first of eight children born to Martin Sr.'s second wife-there being three half-siblings from a previous marriage. Martin's father became a clergyman before retiring as a small farmer, which would have placed John Martin comfortably in the lower middle classes. The status of the family changed in 1838, however, when both parents died of typhus. John Martin was sixteen years old. On the advice of an uncle, the eleven Martin children set sail for New Zealand. Upon arrival, Martin took a job as a pick-and-shovel hand before gaining a contract supplying the militia during the Hutt wars. Martin eventually obtained a letter for credit $(£, 1,500)$ and travelled south, taking up a run that was later declared a goldfield. Martin's personal history does not necessarily exclude him from the middle classes, but it does demonstrate that background is more complicated than a simple categorisation might suggest. ${ }^{67}$

The exact breaks within and between the middle and wage-earning classes in Figure 6 , then, should be treated as guides rather than definitive divisions. The important point is that the Wairarapa wealthy did not come from the British gentry—a break much easier to establish with confidence.

Although those from the white-collar and artisan classes represented the majority of the wealthy, within the cohort those with upper middle-class origins tended to make more

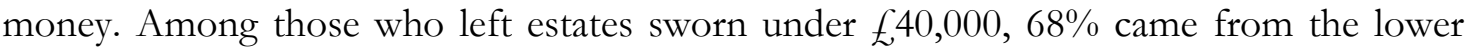
middle class and $6 \%$ from the wage-earning class. This left only $26 \%$ who had upper middle-class origins. Within the wealthier section (those leaving more than $f_{4} 40,000$ ) the balance was shifted in favour of the upper middle class; $45 \%$ of these testators had upper middle-class origins.

With a relatively small cohort there is limited use in focusing too much on the numbers, but it is worth noting that extensive pastoralists were only slightly more likely to come from significant money. R.D. Hill argued of Wairarapa's earliest pastoralists, 'not all

\footnotetext{
${ }^{66}$ For an extended biography of Martin, see McIntyre, pp.96-100.

${ }^{67}$ Indeed, the 'go-down-to-go-up' apprenticeship was, as we shall see in Chapter two, common amongst the middle classes.
} 
were wealthy but most were men of education and initiative and were often of upper-class origin. ${ }^{68}$ It is not clear exactly whom Hill has in mind but only the early Wharekaka Catholics were legitimate members of the British lower gentry. But for these exceptions, the early squatters were almost exclusively of professional origins. Hill, who is only fleetingly interested in the pastoralists' class origins, seems to have been inaccurate about the people in his study, and he was certainly wrong about the people in this one-those few with any claim to upper-class status had left the area by 1876.

Figure 7 demonstrates that the wealthy testators in Wairarapa were mostly of English origins, with a substantial portion of Scots and a small-but-significant section of Irish immigrants. A further analysis of regional origins is also provided. Unfortunately, little is known about the single Dane, Anders Andersen. Andersen was born in Pjetsted, Denmark in 1842 and arrived in New Zealand in 1869. There is little record of him through the 1870s, but in 1880 he bought Woodville (near Featherston) from newspaper

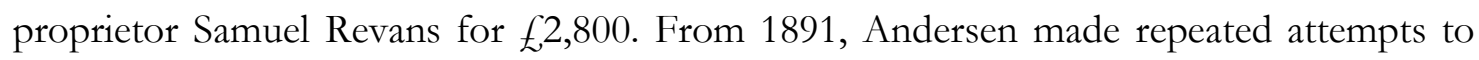
sell or lease the property but was unable to do so until $1906 .{ }^{69}$ Andersen died in 1908, leaving an estate worth $£, 15,646$.

Figure 7: The Geographic Origins of the Wealthy Wairarapa Testators

$\begin{array}{rcc} & \text { Number } & \mathbf{\%} \\ \text { England } & 37 & 57.8 \\ \text { Scotland } & 15 & 23.4 \\ \text { Ireland } & 7 & 10.9 \\ \text { Denmark } & 1 & 1.6 \\ \text { Unknown } & 5 & 7.8\end{array}$

\footnotetext{
${ }^{68}$ Hill, p.25.

69 'Local and General', Wairarapa Daily Times, 22 December 1906, p.4.
} 


\begin{tabular}{ll|ll|ll} 
England & & Scotland & & Ireland & \\
London & 5 & FarNorth & 0 & Leinster & 0 \\
South-East & 5 & Highlands & 5 & Munster & 2 \\
South-West & 5 & North-east & 0 & Ulster & 1 \\
Northwest & 4 & East Lowlands & 8 & Connaught & 0 \\
East of England & 3 & West Lowlands & 0 & Unknown & 5 \\
Northeast & 0 & Borders & 0 & & \\
Yorkshire & 2 & Unknown & 2 & & \\
East Midlands & 3 & & \\
West Midlands & 2 & & \\
Unknown & 8 & &
\end{tabular}

Overwhelmingly, then, the wealthy had their origins in the British middle classes. The remainder of this thesis focuses on the way that these origins, in tension with colonial success, shaped wealthy identity in Wairarapa.

\section{The Extent \& Distribution of Wealth in Wairarapa}

The money itself also tells a story, and in Wairarapa an analysis of estate values demonstrates that there was substantial variation in wealth among the rich. Briefly, a look at marriage networks demonstrates that wealth was not as well distributed across families to the extent that surname variation would suggest.

Figure 8 is a graphical representation of the Wairarapa wealthy's fortunes. The most striking feature of the graph is the dominance of Edward Joshua Riddiford's fortune, which was valued at $f, 584,622$ at the time of his death in 1911. One way of conceptualising Riddiford's wealth is to note that 46,389 people died between 1908 and 1912 in New Zealand. Of the total value of property probated during this period, two per cent of it was Riddiford's. Riddiford's fortune represents $21.5 \%$ of all the wealth probated by the wealthy Wairarapa testators in this study and more than three times that of the next largest wealth-holder. Removing Riddiford's estate gives Figure 9, which demonstrates the variation among the 'lower level' fortunes. The average value of a wealthy Wairarapa testator's estate between 1876 and 1913 was $£, 42,461$ but, as Figure 10 demonstrates, there was significant variation. 
Figure 8: Value of Wairarapa Wealthy Testator's Estates, 1876-1913

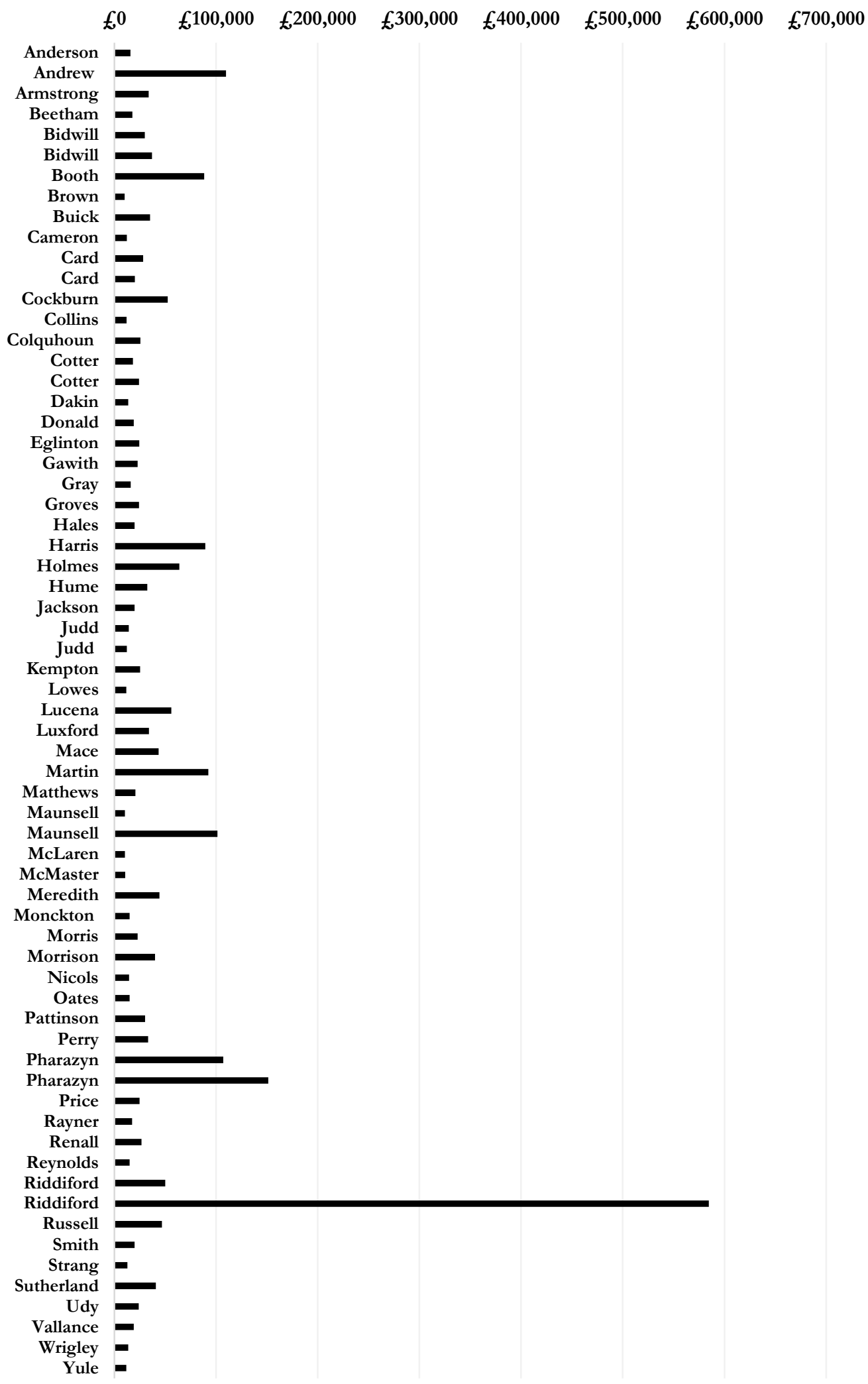


Figure 9: Value of Wairarapa Wealthy Testator's Estates 1876-1913 without Edward Riddiford

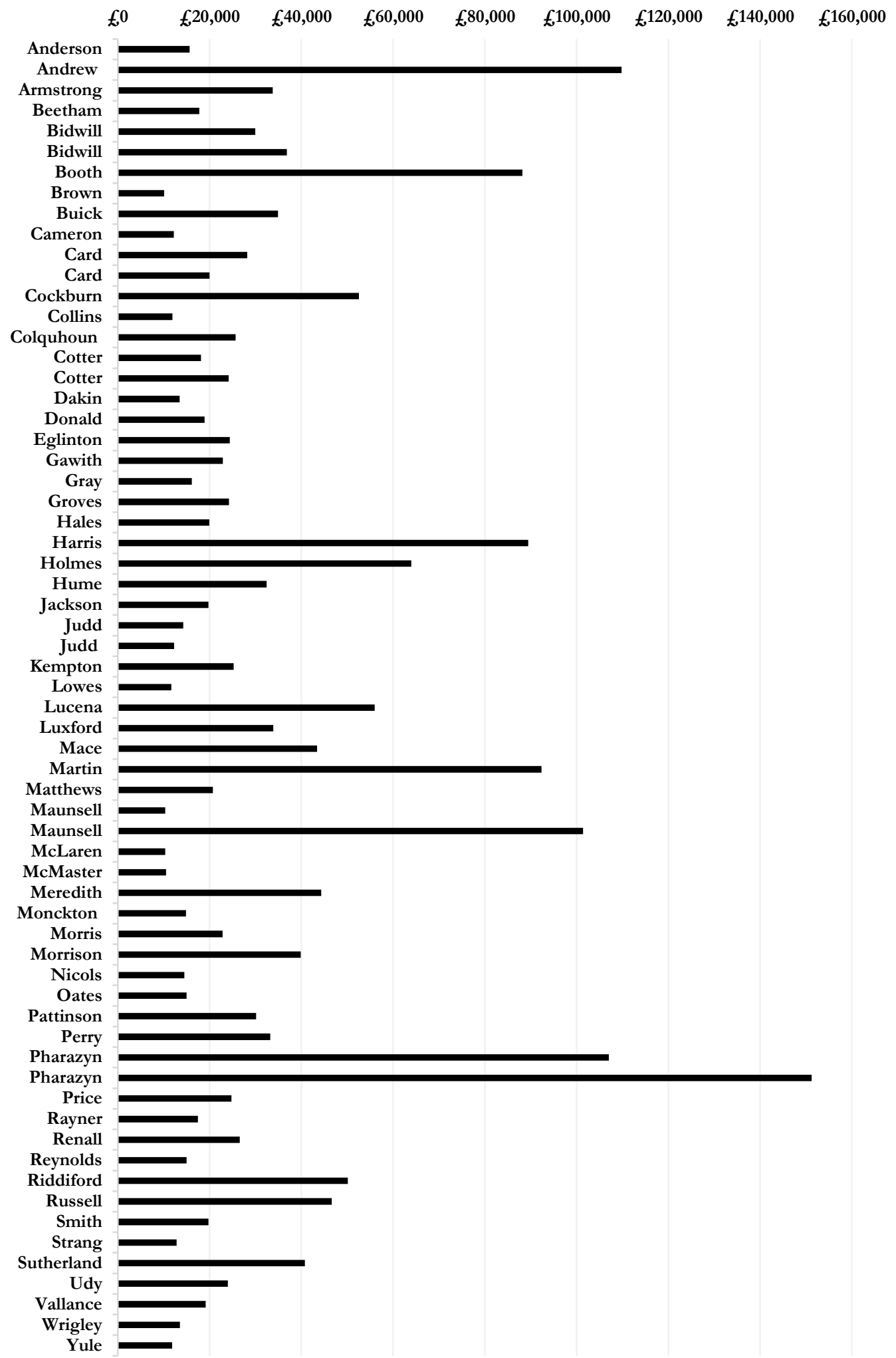


Figure 10: Breakdown of Wealth among Testators

\begin{tabular}{|c|c|c|c|}
\hline & Number & Percentage & $\begin{array}{l}\text { South Island } \\
\text { Percentage }^{70}\end{array}$ \\
\hline Under $£^{20,000}$ & 27 & $41.5 \%$ & $42.8 \%$ \\
\hline$£ 20,000-29,999$ & 14 & $21.5 \%$ & $21.7 \%$ \\
\hline$£ 30,000-39,999$ & 9 & $13.8 \%$ & $10.9 \%$ \\
\hline$£ 40,000-99,999$ & 10 & $15.3 \%$ & $17.4 \%$ \\
\hline$£_{100,000}$ & 5 & $7.7 \%$ & $7.3 \%$ \\
\hline Total & 65 & - & - \\
\hline
\end{tabular}

Another question that arises is the way in which wealth was distributed across families. At first appearances, the Wairarapa wealthy appear to be widely distributed but this proves not to be the case. The Riddifords, Pharazyns, Maunsells, Judds and Bidwills all manage to appear twice in Figure 4 but no other surname appears more than once, apparently leaving fifty-five independent families. The variation in surnames, however, belies the frequency of intermarriage; within the cohort of wealthy testators, one can travel from one surname to almost any other following links of marriage. Charles Bidwill's nine children serve to illustrate this phenomenon. The eldest daughter, Catherine, married Richard J. Barton, son of Richard Barton who was an early leaseholder on Cape Palliser. Robert and Catherine's third daughter, Ruth, was married to Hugh Horsley Beetham (brother of Richmond) in 1879, linking the Bidwills to the largest runholders in the district. Of the remaining children, marriages included Thomas Balfour (a banker who may well have ended up in this cohort but for a move to Napier), and no less than three marriages to the Rhodes family (a wealthy family from Canterbury, the Rhodes feature in McAloon's work). Other marriages include that of Charles Gawith to a daughter of Bennett Pascoe Perry (d. 1894, £33,231), the marriage of Frederick Hales’s (d.1911, $£ 19,921)$ mother to George Luxford $(\mathrm{d} .1905, £ 33,880)$ and the marriage of a daughter of George Mace (d.1907, $£$ 43,401) to a son of Charles Vallance.

\footnotetext{
${ }^{70}$ McAloon's figures have been created by combining tables found on p.29 \& p.56 of No Idle Rich.
} 
There is not space here to delineate fully the extent and meaning of this nuptial network, but two points might be made. First and most obviously, the individuals in this study are more closely related than their separate surnames suggest. Second, the regional variation of Bidwill children's marriages suggests that this was a national phenomenon and that, further, the wealthy identified with a community of rich people beyond their regional boundaries. For these reasons and others, a network analysis of wealthy marriage in New Zealand would be of great benefit.

Wealth, then, was poorly distributed in Wairarapa. We have already seen (in the introduction to this thesis) that the wealthy were an exclusive group among New Zealand wealth-holders (in that less than $1 \%$ of testators in colonial New Zealand left estates worth $£ 10,000)$, but wealthy marriage networks suggests that this exclusivity was a product of, and produced by, intermarriage. And even within the group of the rich, wealth was poorly distributed - there was substantial variation in estate value in Wairarapa.

\section{Conclusion}

This chapter has introduced the wealthy. It has shown that while the wealthy all left much larger estates than the average deceased, there was significant variation. Very generally, the bigger fortunes were left by the large-scale pastoralists who arrived early and ran large flocks of sheep on rough land. Many of the smaller fortunes were left by intensive farmers. Only nine of those working in non-farming industries qualified as wealthy. These non-farming rich tended to arrive later, being more dependent on regional development. Whereas the pastoralists were almost equally likely to come from the upper middle class as they were the lower middle or wage-earning classes, the rest of the Wairarapa testators were much more likely to come from the lower middle class. Most importantly, none of the Wairarapa wealthy came from the upper class. Within Britain, this chapter demonstrated that immigrants tended to come from England, with a sizable group of Scots and a few from Ireland. 


\section{Chapter Two: 'Matters of account between us'-Wealth and Family in the Testamentary Record}

On 31 March 1895, a 92-year-old Charles Pharazyn wrote a letter to his son (also Charles Pharazyn (d.1903, f,151,260)) in London:

In case of my death before you return from England (which I fear is probable) I write this so that there can [be] no possible questions or doubt as to matters of account between us. ${ }^{1}$

While these 'matters of account' were relatively straightforward-Charles had chosen to write off the majority of his son's debts, having 'destroyed' the relevant paperwork as a signal of intent - the fact that Pharazyn chose to write the letter at all indicates an aspect of wealthy life explored in this chapter. That is, for the wealthy in Wairarapa, the end of life was about making important decisions about family and property. Pharazyn's letter demonstrates that these decisions were not made lightly, and it is this central fact that makes the reading of the Wairarapa wealthy's testamentary record so valuable.

In Wairarapa, as in the South Island, a close reading of the testamentary record demonstrates that wealth accumulation was for the family, although Wairarapa widows tended to have less economic agency than those in Canterbury and Otago. This chapter first considers the ways in which sons, daughters and widows appeared in the wills of the Wairarapa wealthy before reflecting on the meaning of these bequests. Specifically, Wairarapa testamentary practices demonstrate that the rich strategised for the future, and tended to promote equality. Lastly, this chapter demonstrates that bequests did not just reflect testators' values, the wealthy also reinforced values in their wills.

Probate files have been used rarely in New Zealand as qualitative sources. ${ }^{2}$ Beyond McAloon, Stephanie Wyse's PhD thesis is the most significant study of probate records in New Zealand. Wyse concludes that women in urban New Zealand had a more active role

\footnotetext{
${ }^{1}$ Letter from Charles Johnson Pharazyn to Charles Pharazyn, 31 March 1895, MS-Papers-0308, Alexander Turnbull Library, Wellington, New Zealand. As it happened, Pharazyn was predeceased by his son. Charles Pharazyns Sr. would live another eight years, dying at the age of 100. His son Charles, to whom he was writing, committed suicide in London a few months before his father's death.

2 As mentioned, Margaret Galt also used probates extensively, but she has been omitted here because her work was strictly quantitative.
} 
in wealth accumulation than has been suggested. ${ }^{3}$ Wyse studied women at all wealth levels, and focused on the urban setting. Her conjecture-that cities were a liberating force in women's economic lives_-requires further research in rural areas to substantiate.

Overseas, probates have formed the basis of several studies of wealth-holders. W. D. Rubinstein pioneered the analysis of probate records in Britain, but several others have approached testamentary records as qualitative sources. ${ }^{4}$ Alastair Owens and David Green, working at times together, at others separately, have used probates in studies of the relationship between property and gender in Britain. ${ }^{5}$ R. J. Morris has also used probates extensively in his work on the English middle classes. ${ }^{6}$ Elsewhere, Livio Di Matteo has analysed wealth accumulation motives in Ontario and Martin Shanahan has studied personal wealth holders in Australia. ${ }^{7}$

Many of these historians have considered the testamentary moment in the context of the 'life course.' According to Owens, the life-course perspective

centres upon the idea that something sociologically meaningful can be learned from studying individuals and their families as they move through various stages or phases of biological and historical time. ${ }^{8}$

The life-course perspective prevents the 'distortion and magnification' that results from looking at moments in the lives of individuals and families as isolated incidents. 'Wyse avoids this isolation by extracting economic information from evidence 'across the life

\footnotetext{
${ }^{3}$ The economic agency of rural New Zealand women is not well established. Wyse hypothesises that 'women and men were more closely matched in terms of economic agency' in the city, but concedes that it is 'worth exploring' Wyse, p.223.

${ }^{4}$ W. D. Rubinstein, Men of Property: The Very Wealthy in Britain since the Industrial Revolution, (London, 1981).

${ }^{5}$ Alistair Owens, 'Gender and the Life Course: Inheritance and Family Welfare Provision in Early Nineteenth-Century England' Social History, vol. 26, no. 3, 2001; David Green, Alastair Owens, Josephine Maltby and Janette Rutterford (ed.), Men, Women and Money: Perspectives on Gender, Wealth and Investment 1850_ 1930, (Oxford, 2011); Alastair Owens and David Green, 'The Final Reckoning: Using Death Duty Records to Research Wealth Holding in Nineteenth-century England and Wales', Arcbives, vol. 66, no. 3, 2013, pp.121.

${ }^{6}$ R. J. Morris, Men, Women and Property in England, 1780-1870: a social and economic bistory of family strategies amongst the Leeds middle class, (Cambridge, 2005), and R. J. Morris 'The Middle-Class and the Property cycle during the Industrial Revolution' in T. C. Smout (ed.) The Search for Wealth and Stability: essays in Economic and Social History Presented to M. W. Flimn,(London, 1979).

${ }^{7}$ Livio Di Matteo, 'Wealth Accumulation Motives: Evidence from the Probate Records of Ontario, 1892 and 1902', Cliometrica, vol. 2, 2008 and Martin P. Shanahan, 'Personal Wealth in South Australia', Journal of Interdisciplinary History, vol. 32, no.1, 2001, pp.55-80.

${ }^{8}$ Owens, p.301.

${ }^{9}$ ibid.
} 
course,' but one need not employ a wide (in terms of bio-temporal scale) range of evidence; the value is in the consideration. ${ }^{10}$ While this chapter focuses on the end of life and the testamentary moment, it does so with a life-course perspective, recognising that the end of life is not a moment that exists in isolation. Further, while this chapter does focus on the end of life for the testator, the variety of positions occupied by beneficiaries in biological time means that we get insight into various stages of the life course; in this case a focus on end-of-life is a more wide-ranging approach than it might first appear.

Perhaps the most important aspect of will-writing in colonial New Zealand (as elsewhere) is that the writing of a will was, for the most part, not legislated for. Those legal restrictions that did exist had little effect on the actions of Wairarapa testators. In 1900, for example, the Testator's Family Maintenance Act made familial provision a legal requirement. As McAloon points out, the Act had a very limited effect on testators' freedom; relatively few cases were heard, and the legislation only required 'sufficient' support by a testator for their family rather than fairness. ${ }^{11}$ Additionally, in Wairarapa the evidence suggests that just as in the South Island, these legal restrictions were less than necessary; testators required little encouragement to make generous provision for their children.

Because of the deceased's freedom to divide their property as they saw fit, inheritance practices were dictated by non-legal forces such as tradition, status and personal preference. ${ }^{12}$ Inheritance practices, then, offer some insight into the mind and identity of the testator. Wyse notes that

while a testator supposedly had the ability to act independently in deciding the disposition of their wealth, it is actually more likely that decisions made were the culmination of many years of personal interactions, giving and receiving, family pressures to both 'do the right thing' and a decision to reward or reprove those closest to them. ${ }^{13}$

\footnotetext{
${ }^{10}$ Wyse, p.15.

${ }^{11}$ McAloon, p.82.

${ }^{12}$ Morris, p.88.

${ }^{13}$ Wyse, p.219.
} 
In this way, wills are shaped by the various facets of their author's identity, and thus reflect the testator's values. ${ }^{14}$

But wills were also personal documents. Morris notes that the writing of the will 'took place within the law but was not directed by the law. ${ }^{, 15}$ This feature of will-writing is demonstrated in the evidence in this chapter. On occasions, the nature of the bequests themselves makes this clear enough-especially in the bequest of meaningful objects. That will-writing was a personal activity is also clear in the rhetoric of the document, a mix of boilerplate and intimate language. Morris argues that

the will presented an enclosed universe of men and women, adults and children. Their relationships were defined by carefully chosen attributes: my daughter, my dear wife, my friend. ${ }^{16}$

This sort of testamentary intimacy is a reminder of the will-writer's agency. An understanding of this agency underlines the ways in which testators were able to use their will as a didactic tool, reinforcing values in others.

Testamentary decisions, then, took place within their social and legal context, both reflecting and reinforcing values. Of course, isolated wills are difficult to read-there is simply no way to account for minor anomalies. But by 'zooming out', and systematically analysing the whole, a vision of wealthy identity in private appears. A systematic reading of Wairarapa testamentary practices demonstrates an identity consistent with the cohort's middle-class origins. That is, above all else, the wills reflect the importance of economic survival to wealthy families in Wairarapa.

\section{The Family in the Will—Bequeathing Property, Bequeathing V alues}

Testamentary practices and earlier-in-life efforts to 'set up' children for economic success demonstrate the importance of planning for the family's future to the Wairarapa wealthy (although sons and daughters were planned for in different ways). Importantly, the

\footnotetext{
${ }^{14}$ As Morris notes, the way in which people in similar situations did the same thing with their property adds further weight to the argument that these aspects of identity are central to testamentary decision making. Morris, p.88.

${ }^{15}$ Morris, p. 97.

16 ibid.
} 
structure of bequests to sons and daughters by the Wairarapa wealthy mirrors that of McAloon's South Island rich.

Wairarapa testators aimed to set up their sons in business, but the process often began long before a parent's death and sometimes continued for a significant period thereafter. Among farmers, sons would often serve a sort of apprenticeship, managing or leasing their father's farm. McAloon argues that in the South Island, 'often one generation set up the next while both were still living. ${ }^{, 17}$ In the Lower North Island, things were no different. Charles Bidwill (d.1884, $f 29,971)$ was one of those to set his sons up on the farm before he died. In 1879, Bidwill leased Pihautea to his sons John and William (then aged twenty-five and twenty-one, respectively) to be joined by their younger brother Charles (sixteen years old) when of age. Writing his will three years later, Charles Sr. divided the estate into three 1,000-acre blocks, bequeathing one to each of the three sons. ${ }^{18}$ The three sons opted to work together, trading under the name Bidwill Bros., and expanded operations slowly.

Edward Joshua Riddiford (d.1911, £584,622) served an especially lengthy 'apprenticeship'. He attended Christ's College in Christchurch and then travelled to Australia to stay with his grandmother Harriet Evans at sixteen years old. In Melbourne, Riddiford attended Scotch College before finding work droving cattle from Queensland to Victoria. He then travelled back to New Zealand for the Otago goldfields at which location he received a letter from his mother, Harriot: 'There is much to be done to put it [Dan Riddiford's second run, Te Awaiti] in proper training, and I consider, dear Edward, you are the person who ought to do it. ${ }^{19}$ Despite the apparent necessity of Edward returning to Te Awaiti, he was not to receive ownership of his father's properties. Riddiford took up management of Te Awaiti in 1862, and the family's Orongorongo River run in 1869. When Dan Riddiford died in 1875, Edward received the properties that he had been managing.

\footnotetext{
${ }^{17}$ McAloon, p.83.

18 Bidwill Probate File, 1884, Series 6029, No. 2144, ANZ/W.

19 Letter from Harriot Riddiford to Edward Joshua Riddiford, quoted in Roberta Nicholls, Riddiford, Edward Joshua', Dictionary of New Zealand Biography. Te Ara - the Encyclopedia of New Zealand, available at http://www.teara.govt.nz, updated 30 October 2012.
} 
The 'apprenticeship', in which a young farmer undertook a managerial role or leased their father's farm, left little doubt that the father retained control. This was especially true of John Martin (d.1892, £.92,358), who removed J. D. Baird from his managerial position at Otaraia, preferring his son Edward. According to McIntyre, the relationship soon dissolved as John grew frustrated at what he considered to be Edward's wastefulness (and, apparently, his alcoholism). ${ }^{20}$ Family legend has it that 'Edward threw the station books at his father's feet, shouting 'Do it yourself!', and stormed out. ${ }^{21}$ Edward left for Australia and Martin replaced him with another son, Arthur. There were apparently fewer problems this time, for when Martin died in 1892, it was Arthur who received Otaraia. Despite Edward's apparent ignominy, he received an equal share of Martin's substantial residual estate along with his eight siblings. ${ }^{22}$

There is evidence of these 'apprenticeships' in the Wairarapa wills. In some cases, wills make it clear that substantial provision had already been made for sons, without the nature of any transfer of property being known. John Groves (d.1905, £24,203), a sheep farmer at Tinui, requested that his estate be split equally among all his children except his son John and daughter Grace who had both 'received a fair share of my estate during my lifetime. ${ }^{23}$ Charles Harris (d.1913, f89,450), another sheep farmer, made it clear that significant money was only available to his sons if it was used to help set them up in business. Harris's sons were evidently in danger of losing their lease, for he left them $£ 9,500$ in the event of their lease being declared void by the Privy Council, but not otherwise. ${ }^{24}$ Similarly, Henry Jackson $(\mathrm{d} .1905, f 19,759)$ dictated that his son Ernest should receive all his remaining property-his other two sons and four daughters had been 'provided for' during lifetime. ${ }^{25}$

Farmers who wanted to remain in control of their existing farm chose to buy separate land for their sons. In 1866, Frederick Monckton (d.1909, f1883), who farmed a relatively small estate at Newstead, purchased another 1,000-acre property, renamed it

\footnotetext{
${ }^{20}$ McIntyre, p.112.

21 ibid.

${ }^{22}$ Martin Probate File, 1892, Series 18576, Accession W3265, No. 3854, ANZ/W.

${ }^{23}$ Groves Probate File, 1906, Series 18575, Accession W5447, No. 129, ANZ/W.

${ }^{24}$ Harris Probate File, 1913, Series 18576, W5447, No. 7/13, ANZ/W.

${ }^{25}$ Jackson Probate File, 1905, Series 6029, No. 9435, ANZ/W.
} 
Lowlands and placed his son Owen on the land along with his eldest daughter Birdie and six of the younger Monckton children. Birdie was to look after the household and the younger children while Owen farmed. As Owen learned the practical side of farming Leslie, another of Monckton's sons, was put 'into a bank for two years' in an effort to learn the financial side of the business. ${ }^{26}$ Finally, in 1890, Monckton sold Lowlands to the Pharazyns. With the proceeds, he purchased a farm near Eketahuna and Leslie and Owen went into business together. Frederick Monckton bought another farm near Carterton for his fourth son, Ted. Once again, Birdie was sent along with him to take care of domestic affairs. ${ }^{27}$ By the time Monckton died in 1909, the properties had officially changed hands.

The desire to help family members 'get ahead' applied to those beyond the immediate family. Often, testators without children made significant bequests to nieces and nephews. ${ }^{28}$ Robert Cockburn (d.1906, $\left.£ 55,551\right)$ died with neither widow nor children. Cockburn had gone into farming with his nephew Alexander Mutrie and ceded 'all my interest in threshing machine and other articles used and employed connection therewith. ${ }^{29}$ Thereafter, Cockburn made a lengthy list of bequests to his nephews and nieces, including those to whom he was only related by marriage. All told, Cockburn made more than twenty specific bequests of various values (ranging between $£ 200$ and $£, 900$ ) to his young relatives. What is more, it was not only those who had no other use for their money who gave to their wider family; both Hanna Card (d.1912, £28,179) and the lawyer Charles Gawith (d.1911, £22,876) made bequests to nieces and nephews alongside their own children. ${ }^{30}$

Other efforts to help younger relatives in their economic lives could be made during a life time. Edward Maunsell (d.1908, f10,306) sent his young cousin Daniel to Donald McLean in Wellington along with a letter:

\footnotetext{
${ }^{26}$ Joblin, p.47.

27 Joblin, p.89.

${ }^{28}$ McAloon, p.88 McAloon notes that 'the rich uncle or aunt was a real figure in colonial New Zealand.' In Wairarapa, every childless testator except Richmond Beetham made bequests to nieces and/or nephews. This was a total of four testators.

${ }^{29}$ Cockburn Probate File, 1906, Series 18575, Accession W5447, No. 132, ANZ/W.

${ }^{30}$ Gawith Probate File, 1911, Series 18576, Accession 5447, No. 36/11, ANZ/W; Card Probate File, 1912; Series 18576, Accession W5447, No. 40/12, ANZ/W.
} 
The bearer of this is Daniel Maunsell one of my cousins who is asking a respectable position and employment in the Colony and has been advised to see you with a view to your assistance. I think you will find him well qualified to fill any clerical post...you may find him some employment as private Secretary or a cadetship...Hoping that I am not presuming too much in soliciting aid from you for a comparative stranger, though the name is familiar to you. ${ }^{31}$

Maunsell was the son of the well-known missionary Robert Maunsell, and evidently hoped his name might impress McLean. Although Maunsell's gesture was relatively minor, it is a further reminder of the importance of 'setting up' young relatives. Here, a life course perspective demonstrates the importance of the inter-generational economic relationship; by consistently setting up younger male relatives in business the older generation could help to ensure the family's continued economic success.

The daughters of wealthy Wairarapa testators were not set up in business by their fathers, but their futures were also planned for-testators made bequests to help daughters head towards prosperous families of their own. These might take the form of managerial roles, bequests to sons-in-law or absolute payments to daughters. Most frequently, however, daughters received their bequests as life trusts which were intended to look after subsequent generations.

McAloon reports that in the South Island, daughters 'were unlikely to receive assistance toward a start in business (although some did). ${ }^{32}$ In Wairarapa, this did not occur at all across the probates studied. However, this did not mean that daughters were always prevented from being involved in business. James Donald's daughter Bessie (James Donald died in 1899 with $f_{18,892)}$ took over as manager of Tarureka Dairy Factory following James's death. Bessie travelled to Britain to visit dairy factories and creameries and took a course of practical study at Inglewood Dairy School. As far as can be told, however, Donald did not intend for Bessie to own the factory outright. The operation

\footnotetext{
${ }^{31}$ Letter from E. S. Maunsell to Donald McLean, 1876, MS-Papers-0032-0451, Alexander Turnbull Library, National Library, Wellington, New Zealand.

32 McAloon, p.86.
} 
remained in trust (and Bessie was not a trustee). Family history tells that Bessie frequently had attempts at expansion undermined by her brother Quentin, who was a trustee. ${ }^{33}$

Just because daughters were not themselves encouraged into business does not mean that fathers did not plan for their daughter's future-rather that daughters were rarely given control of their futures. ${ }^{34}$ Sometimes, testators provided for their married daughters' futures by treating sons-in-law as sons. Jacob Matthews (d.1908, £20,179) was a relatively small-time farmer at Opaki and was the father of two sons and one daughter. In his will, Matthews divided his farm into rough halves, one of which for a son Alfred, and another for his daughter Mary. Both properties would be held in trust. While Mary's half was under her name, it was stipulated that the land was currently in the occupation of my son in law Charles Wilton' and it was clearly intended that Charles should continue farming. Charles Wilton and Alfred Matthews were named as the estate's trustees. ${ }^{35}$ Matthews's bequests reflect a 'balancing act'; by enabling his son-in-law to continue business on his land, Matthews improved his daughter's chances of economic security. It is important to note, however, that Matthews stopped short of bequeathing Wilton the property absolutely, which would have allowed him (Wilton) to dispose of the property himself. By keeping the farm in trust, Matthews secured his family's economic success.

Bequests to daughters were either absolute or in trusts that passed to future generations. The significance of these bequests might not be immediately apparent. A testator had to decide whether to make a bequest absolutely or to provide long-term payments. Generally, limiting a daughter's access to her inheritance through the use of regular payments restricted her economic agency. A daughter's receipt of her bequest in trust might also be intended to secure an inheritance for the sons of daughters. ${ }^{36}$ Conversely, an absolute payment maximised a daughter's ability to make economic

\footnotetext{
33 Graham Donald, From Tulliallan to Tarureka: The history of James and Elizabeth Donald, Featherston and their descendants (Self-Published, 1990), pp.45-46.

${ }^{34}$ One might argue that sons encouraged into businesses by their fathers had little control themselves, but the most important distinction is that daughters were much less likely to receive the opportunity to earn their own money.

${ }^{35}$ Matthews Probate File, 1908, Series 18575, Accession W5447, No. 174, ANZ/W.

${ }^{36}$ McAloon, p.86.
} 
decisions, and inasmuch allowed her economic agency. ${ }^{37}$ In Canterbury and Otago, 67.2\% of daughters received their inheritance absolutely, while only $19.8 \%$ received theirs in a trust. The remaining 13\% was made up of three categories: daughters who received very little, situations in which both sons and daughters received their inheritance in trust and those in which no pattern was discernible. ${ }^{38}$

In Wairarapa, daughters' bequests followed a similar distribution; as shown in Figure 11, daughters received their inheritance in a life trust $20.8 \%$ of the time. They were slightly more likely ( $75 \%$ versus $67.2 \%$ ) than South Island daughters to receive their inheritance absolutely. In Wairarapa, only $2 \%$ of bequests followed no discernible pattern. While the proportion of daughters who had their economic agency restricted by trusts $(20.8 \%)$ may seem relatively low, it should be noted that no sons received their inheritance in this way in Wairarapa. ${ }^{39}$ Daughters were much more likely than sons to have their economic agency restricted in their father's will.

On some occasions, bequests to daughters did not fall easily into either the 'absolute' or the 'life trust' categories. John Cameron (d.1900, £12,231), for example, left $f 50$ annuities for each of his daughters, to be discontinued upon marriage. At the time of marriage, the daughter would receive an absolute bequest of $£, 500$, to be kept for her sole and separate use. ${ }^{40}$ It is not known how many daughters Cameron had, but it is likely that they were within ten years of marriage (given the fact that Cameron died aged 68 and the average age of marriage was relatively young), meaning the majority of the Cameron daughters' bequests would have been in the form of an absolute payment. However, while the Cameron daughters probably received the majority of their inheritance absolutely, their ability to make economic decisions was still restricted-they were not to receive their inheritance until married. Nevertheless, in cases like the Cameron bequest, the perceived

\footnotetext{
37 Of course, a daughter's marital status might act as a mitigating force upon her economic agency. For a full discussion of married women's legal status see Bettina Bradbury, 'From Civil Death to Separate Property: Changes in the Legal Rights of Married Women in Nineteenth-Century New Zealand', New Zealand Journal of History, vol. 19, no.1, 1995, pp.40-67.

${ }^{38}$ McAloon, p.87.

39 That is, excluding those cases in which all children (both sons and daughters) were received their share of the estate in trust.

${ }^{40}$ Cameron Probate File, 1900, Series 18575, Accession W5447, No. 60, ANZ/W.
} 
largest component of the bequest has been favoured-probably skewing the data slightly in favour of 'absolute inheritance'.

Figure 11: Bequests to Daughters ${ }^{41}$

$\begin{array}{rccc} & \text { Number } & \mathbf{\%} & \text { South Island \% } \\ \text { Absolute inheritance } & 36 & 75 & 67.2 \\ \text { In-trust } & 10 & 20.8 & 19.8 \\ \text { No pattern } & 2 & 4.2 \% & 6.0 \\ \text { Total } & 48 & - & -\end{array}$

Figure 12: Relative Size of Bequests to Sons and Daughters

\begin{tabular}{rcc} 
& Number & \% \\
\hline Substantial Equality & 28 & 60.9 \\
Son(s) favoured & 14 & 30.4 \\
\hline Daughter(s) favoured & 3 & 6.5 \\
No Pattern & 1 & 2.2 \\
Total & 46 & -
\end{tabular}

In Canterbury and Otago, daughters did not always enjoy equal inheritance with their brothers even if they did receive their inheritance absolutely. In $53.9 \%$ of cases,

${ }^{41}$ For the purposes of comparison with McAloon's data, it is assumed that when testators spoke of 'children' they meant both sons and daughters As McAloon states, this means that the absolute inheritance of daughters may well be overstated in the above data. McAloon, p.87. In the South Island, McAloon reports that $4.4 \%$ of daughter's received 'minimal' property and that in $2.6 \%$ of cases, all children received their property in trust. 
daughters and sons were treated with 'substantial' equality by testators. ${ }^{42}$ Equality was similarly important in Wairarapa. In $60.9 \%$ of cases, the bequests of daughters and sons demonstrated 'substantial equality.' In another significant portion-30.4\% of cases—sons were clearly favoured over daughters, and in a few cases $(6.5 \%)$ daughters were favoured over their brothers.

Sons and daughters were raised with divergent goals (most typically, economic independence for sons and a prosperous marriage for daughters). Certainly, during the life of a parent (most often a father) sons received much more encouragement towards enterprises of their own than did daughters. When it came to bequests, however, sons and daughters received approximately equal shares, demonstrating that while methods of planning diverged for sons and daughters (in ways that were restrictive of daughters' economic agency), testators intended to ensure the success of all their children.

\section{Widows in their Husband's Will}

Wealthy women in the Wairarapa undertook a variety of economic roles, but systematic study suggests that generally, rural women had less economic agency than urban women in New Zealand.

In Wairarapa, some wealthy women took active roles in wealth accumulation. On James Donald's dairy farm, for example, James's wife Elizabeth and their four daughters did the majority of the milking. On small farms in particular, enterprise tended to require multiple hands and wives often took an active role. In an 1865 letter to her sister, Jane Oates (mother of Joseph, d. 1912, £14,989) wrote:

...We have gota hundred sheepe to sell but thare are verey bad sale now. We had more than 100 lambs this last year. There is 200 ackers of land adjoining ours I expect will be sould before long and the woman that has got it to sell wants $£ 300$ and fiftey for it Charley Edwards thinks she would take $£, 300$ for it in redey money

\footnotetext{
42 The use of the word 'substantial' reflects the fact that in many cases, daughters received bequests that were only roughly equal. James Armstrong, for example, left a bequest of $f, 5,000$ to each of his daughters, with the residue being split between sons. Bequests like Armstrong's depend on the number of daughters and sons, as well as the size of the estate; it is often difficult or impossible to say if either was favoured.
} 
for land is getting verey dear here and we could boy it if I had got the money that Dear farther left me but I don't like to boy it and pay intrest for intrest is ten persent hear... ${ }^{43}$

Although it is not clear what forms of work Oates was involved in, her letter clearly implies some level of economic involvement. The hotelkeeper Hanna Card probably had the most significant involvement in business. The Empire Hotel's Cyclopedia entry stressed her work: the hotel was 'under the critical eye and excellent management of Mrs. Card, who is thoroughly qualified, having had a long experience of hotel life. ${ }^{, 4}$

In other cases, women maintained chiefly domestic roles. Catherine Bidwill, wife of Charles (d.1884, f29,971) was remembered by her family as being almost exclusively concerned by domestic affairs:

Her house was her home, and she rarely left it, all her thoughts were centred upon it, and upon the right and proper way to rear. A modest and unassuming woman, whom thousands of people in the Wairarapa have hardly ever seen. All her married life was passed at Pihautea. ${ }^{45}$

Donald McLean's description of Mary McMaster (wife of the pastoralist Angus McMaster, d. $1888 £ 10,539)$ followed along similar lines: 'She manages her household affairs very quietly and with great ease and comfort to herself she is evidently a woman with excellent good sense and very kind. ${ }^{46}$ Unfortunately, qualitative evidence is hard to come by-rural women rarely left significant records.

The paucity of material in the 'traditional record' on rural women's economic lives is a problem, and here too a more systematic approach is helpful. McAloon identifies the dangers of generalisation, writing that in the South Island 'themes of women, wealth and family tend to be written in the long shadow of Lady Barker and her brief sojourn on a high country station in the 1860s. ${ }^{47}$ While Lady Barker has no direct equivalent in the

\footnotetext{
${ }^{43}$ Reproduced in Robin Holmes \& Allan Farley (ed.), Dear Sister: Letters between a pioneer Wairarapa family and relatives in rural England 1856-1883, (Masterton, 2006).

44 'Empire Hotel', Cyclopedia, Wellington, p.857.

${ }^{45}$ Excerpt from family history 'Bidwill of Pihautea', reprinted in 'Woman's Share', Evening Post, 15 October 1927, p.8.

${ }^{46}$ Donald McLean, quoted in McIntyre, p.51.

${ }^{47}$ McAloon, p.75.
} 
North Island (in terms of influence), the dangers of over-enthusiastic generalisation remain.

Fortunately, probate records provide a systematic and quantitative insight into the economic agency of women. To be more specific, the frequency with which male testators named their wives as administrators serves as an indicator of widows' economic agency. The term 'administrator' is used here to mean either an executor or trustee of the will. While slightly different roles — an executor 'executed' the will, making the initial split of the testator's property, whereas a trustee was responsible for the ongoing affairs of the estate-both imply a level of economic agency. McAloon notes that the 'naming a widow as a trustee or executor at least implied that she had some familiarity with the business affairs of the family. ${ }^{48}$ In the South Island, McAloon reports that 283 male testators named their widows as administrators of their will out of a population of 604 (made up of those who left widows that might have been named). ${ }^{49}$ This proportion $(46.9 \%)$ was considerably lower in Wairarapa, where only $29.7 \%$ of widows were named as administrators of their deceased husband's estate. The relative infrequency with which wealthy men in Wairarapa named their widows as administrators suggests that the economic agency of rural women was more restricted than in urban spaces.

The infrequency of widow's administration adds further weight to Wyse's suggestion that rural wives enjoyed less economic agency than those in cities. Wyse suggests that 'cities arguably also opened up new opportunities for economic activity that were otherwise unavailable in more rural contexts. ${ }^{50}$ She adds, citing the relative frequency of female-headed households in the city: 'Clearly, independent women were drawn to cities. ${ }^{51}$ Although Wyse looks at women at all wealth levels and focuses on the content of women's wills rather than the appearance of wives in the wills of their husbands, her argument for a greater level of economic agency for women in the colonial city is supported here. Widows were less likely to be named as administrators in an exclusively

\footnotetext{
48 McAloon, p.78.

49 ibid.

${ }^{50}$ Wyse, p.12.

51 Wyse, p.61. In 1916, 19\% of urban households were headed by women, compared to just $10 \%$ of rural households. Wyse highlights other inequalities, too. She notes that women in cities were much more likely to leave estates than those in rural areas and that the value of those estates tended to be higher.
} 
rural area (Wairarapa) than they were in areas that include both urban and rural testators (Canterbury and Otago)..$^{52}$ It seems that farming's dominance in Wairarapa restricted roles as executors and/or trustees for widows; McAloon notes that in the South Island, 'Male farmers were a little less likely to leave their widows as executors or trustees than other rich men. ${ }^{53}$

There are also trends in the Wairarapa data that are similar to those identified in the South Island. Widows, when they were named as administrators of wills, were named alongside various men. Most frequently $(57.1 \%$ of cases in which widows were named administrators), widows were named along with their sons; $28.6 \%$ of the time they were named administrators in common with friends, and in the remaining $14.3 \%$ of cases, they were named with solicitors or bankers. ${ }^{54}$ McAloon found similar results in the South Island, although among those named administrator, Wairarapa widows were less likely to be named in the role without any male accompaniment. ${ }^{55}$ The apparent reluctance of Wairarapa testators to name their widows as sole administrators is further evidence of the reduced economic agency of Wairarapa widows.

While looking at the prevalence of administration roles for widows is perhaps the most systematic way of analysing women's economic agency, it should be noted that in individual cases a failure to be named as an administrator might not imply a lack of economic role. In a few cases, male testators assigned their widows positions of economic power but did not name them as administrators. Henry Holmes (d.1911, f,63,959), for example, elected not to name his wife Sidney as either an executor or trustee of his estate but she remained the will's major beneficiary. Holmes left his widow a $£, 500$ bequest, as well as stipulating that income generated by the trustees should be directed to her. What is more, Sidney maintained discretionary power despite her apparently diminished role:

\footnotetext{
${ }^{52}$ It might be added to this that the greatest degree of primary economic activity by any of the women in this study was exhibited by Hanna Card, a hotelkeeper rather than a farmer.

${ }^{53}$ McAloon, p.80. McAloon used 1,042 probate records. This large data set allowed him to parse statistics further than is meaningful in this study. A breakdown of economic agency according to occupation here, for example, would feature numbers so small as to be statistically insignificant.

54 These decisions were made in their legal context. It is worth noting that widows were not legally allowed to act as sole executors until after 1908. Wyse suggests that this practice did become much more common after in subsequent years. Wyse, p.228.

${ }^{55}$ McAloon, p.79.
} 
Holmes dictated that his trustees could liquidise any of his property 'with the consent in writing of my said wife during her widowhood. ${ }^{56}$ Holmes's bequest demonstrates that the naming of a widow as administrator of the will is not the only measure of women's economic agency within the testamentary record.

In other cases, male testators went beyond naming widows as administrators. William Smith (d.1903, £19,776) named his wife Isabella trustee of his estate in common with their sons Robert and Steven. He wrote in his will:

I direct that my trustees shall permit my wife so long as she shall remain my widow to carry on the business or occupation of a runholder and farmer at present carried on by me or any such business I shall be carrying on at the time of my death. ${ }^{57}$

Smith added that his widow should receive 'the annual income produced by any trust property... including the profits of the said business or occupation.' In many cases, the income generated by a trust was directed towards a widow while the children were minors but this was not the case in the Smith family. It is unknown exactly how old Isabella's sons Steven and Robert were, but when William died Isabella was already sixty-three, making it unlikely that the sons were considered too young to take an active role in the business.

The contents of the wills-the bequests themselves—also suggest ideas about women's economic agency. Male testators had several options available to them. Firstly, husbands could leave a widow the bulk of the estate. The bequest of the majority of an estate to a widow suggests, among other things, faith in a widow's economic decisionmaking. A male testator also had to decide between long-term, regular payments and the bequest of an absolute legacy. As discussed in the case of daughters, absolute bequests implied economic agency whereas regular bequests restricted the economic options of the beneficiary.

To make these broad separations-between absolute and long-term, majority and minority payments - is to generalise, never mind the proposed associations to bequest motives. Richmond Beetham (d.1912, £,17,730), for example, stipulated that his widow

\footnotetext{
${ }^{56}$ Holmes Probate File, 1911, Series 18576, Accession W5447, No. 20/11, ANZ/W.

${ }^{57}$ Smith Probate file, 1903, Series 6029, Accession W3265, No. 8180, ANZ/W.
} 
receive her bequest (all income from trust) in quarterly instalments, apparently denying her control, but he also determined she should receive it for life, free of anticipation in marriage, and that she should have ownership of the estate to do with as she liked upon her death. While these complications limit the usefulness of reading individual wills in isolation, 'zooming out' mitigates their effects.

\section{Figure 13: Bequests to Widows}

\begin{tabular}{|rcc|}
\hline & Number & \% \\
\hline Bulk absolutely & 1 & 2.3 \\
\hline $\begin{array}{r}\text { Some absolutely } \\
\text { Bulk over lifetime or } \\
\text { widowhood }\end{array}$ & 2 & 4.8 \\
\hline $\begin{array}{r}\text { Some over lifetime or } \\
\text { widowhood }\end{array}$ & 21 & 42.8 \\
Total & 42 & 50 \\
\hline
\end{tabular}

In half the cases, wealthy male testators in Wairarapa made smaller bequests to widows, spread out over a lifetime or widowhood. There are numerous examples: the pastoralist James Armstrong (d.1880, £33,739) left his widow Eleanor all his 'Household Effects' (a common bequest to widows) as well as 'fifty pounds for her immediate occasion' (legal restrictions on woman's property ownership meant they might find themselves in a difficult financial position immediately after the death of their husband) and an 'annuity of two hundred pounds and in addition a sum of fifty pounds for every child who may be residing with and be maintained by her. ${ }^{558}$ Armstrong's $f^{200}$ annuity was about average among those bequeathing specific annuities. At the top end Charles Bidwill (jr.) (d.1902, £36,831) left an annuity of $£, 500$ and, at the bottom end of the scale, the farmer Henry Jackson left his widow Sarah an annuity of just $£ 50 .^{59}$

\footnotetext{
58 Armstrong Probate File, 1880, Series 6029, Accession W3265, No. 1502, ANZ/W.

59 The value of a widow's share does not seem to have depended much on the extent of a testator's wealth. William Booth (d.1903, $\left.f_{8} 8,208\right)$ left an annuity of $£ 200$ while Angus McMaster $(\mathrm{d} .1888, \ldots 10,539)$ left a greater annuity $(£ 300)$ to his widow Hannah despite leaving an estate less than an eighth of the size of Booth's.
} 
Slightly less often-in $40.5 \%$ of cases-widows received the bulk of the estate

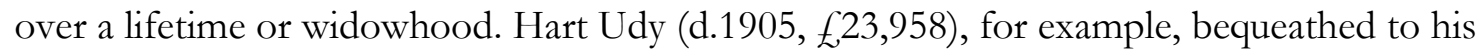
widow Elizabeth occupation of 'my house', $£, 50$ for her 'immediate necessities' and 'during her widowhood...the net income to arise from all my property. ${ }^{60}$ Udy's children all received bequests of land but were required to pay rent to Elizabeth for the duration of her life. Others were slightly less generous, but followed along similar lines. William Judd (d.1906, £12,259) left a bequest of $£, 500$ to his daughter Ethel but dictated that the remainder of his estate should be liquidised and invested, the entire income to be paid to his widow. Following her death, the trust would be split between all children equally. ${ }^{61}$ These widows, however, rarely had the right to dispose of this property at the end of their lives. Elizabeth Udy, for example, despite being the major beneficiary of her husband's will for the duration of her widowhood, was not given control.

In a very few cases, widows received significant property absolutely, and with it a measure of economic autonomy. Charles Pharazyn (d.1903, £151,260) declared that his trustees-his widow Maud and son Charles_-should invest $£, 10,000$ on behalf of his daughter Frances. The remainder of Pharazyn's estate (probably still more than $£ 100,000$ after the payment of expenses, duties and debts) would be split between his widow Maud, and his children (excluding Frances)—each would receive an equal share. These shares were obviously intended to be large- the share of one of Charles' sons was directed to be $£, 5,000$ less than the others. John Andrew (d.1907, f109,786) at Ica on the East Coast made a similar bequest—having his estate split equally and absolutely between his widow and four children (three sons, one daughter). ${ }^{62}$

The importance of this relationship-between bequests to widows and the economic autonomy of widows - is underlined by returning to the Cards in Featherston. In 1909, when John Card died aged seventy-three, his son John Wiltshire Card was already practising law_certainly old enough to receive his inheritance. The Cards also had daughters who remained unmarried — a period of a woman's life during which she usually received financial assistance from her father. Despite all this, Card's will read:

\footnotetext{
${ }^{60}$ Udy Probate File, 1906, Series 6029, No. 9779, ANZ/W.

${ }^{61}$ Judd Probate File, 1911, Series 18576, Accession W5447, No. 14/11, ANZ/W.

${ }^{62}$ Andrew Probate File, 1907, Series 6029, Accession W3265, No.11102, ANZ/W.
} 
I give devise and bequeath the whole of my property and estate both real and personal and wheresoever situate unto my wife Hanna Card for her own use and benefit absolutely. ${ }^{63}$

When Hanna died just three years later in 1912, she split her estate equally between her three children. ${ }^{64}$ It seems more than a coincidence that the only widow to be the sole beneficiary of her husband's will was Hanna Card. That a bequest signifying economic agency was received only once, by a widow working in an industry (hotelkeeping) in which women typically had above-average economic involvement is a reminder of the meanings within wills—and gives added weight to the total absence of any other such bequest.

Despite the examples of a very few, the majority of widows had their economic agency restricted by their husband's will. Overwhelmingly, the bequest motive towards widows by male testators in Wairarapa seems to have been to keep them in relative comfort. Nothing illustrates this tendency better than the prevalence of the 'access-todwelling' bequest. The Dane Anders Andersen (d.1907, f15,646) was one of many who left their widow dwelling access: 'as to my dwelling house and land at Featherston known as 'Duncroft' for my wife during her lifetime'. ${ }^{65}$ John Rayner (d.1903, £17,432), Hart Udy, Edwin Meredith (d.1907, £44,329), James Strang (d.1895, £12,285) and others made similar bequests. Once again, these results display a diminished economic agency for Wairarapa widows. McAloon reports that in the South Island ' $16.7 \%$ of widows were left with economic autonomy in terms of significant absolute property. ${ }^{, 66}$ If in Canterbury and Otago, 'the persistence of the family fortune was in the unfettered discretion of the patriarch, with little autonomy for wives,' widows of wealthy husbands had even less economic agency in Wairarapa. ${ }^{67}$

While widows' appearance in the testamentary record might disguise their economic involvement, it is a good measure of relative involvement. The failure of rich male testators in Wairarapa to make significant bequests to widows does not only reflect ideas about the ability or appropriateness of woman property-owners (although such ideas

\footnotetext{
${ }^{63}$ John Card Probate File, 1909, Series 6029, Accession W3265, No. 11889, ANZ/W.

${ }^{64}$ Hanna Card Probate File, 1912, Series 18576, Accession W5447, No. 40/12, ANZ/W.

${ }^{65}$ Anderson Probate File, 1908, Series 6029, Accession W3265, Record No. 11333, ANZ/W.

${ }^{66}$ McAloon, p.82.

${ }^{67}$ McAloon, p.83.
} 
played some role). The relative equality demonstrated between sons and daughters suggests that widows tended to receive such small shares not because they were women but because they were wives; their husbands were favouring future generations. The fact remains, however, that widows' agency was restricted in these bequests, and that this occurred to a greater extent than in the South Island.

\section{Testamentary Custom and Practice}

Stepping back, some discussion of bequest motives might be made. Although public discussion framed the testator's role as primarily informed by duty, the record suggests a more complicated picture. Specifically, three interrelated motivations can be identified: planning for the future, providing equal opportunities, and leaving a legacy. Taken together, these motives signify a middle-class approach to the family's economic life, demonstrating the on-going importance of the wealthy's origins in determining their private habits. ${ }^{68}$

Parliamentary debate on the Testator's Family Maintenance Bill in 1900 suggests that bequests to widows and children were primarily seen as the paternal duty of the male testator to his dependents, and were much less often seen as an acknowledgment of the whole family's contribution to the accumulation of capital. The 1900 Bill was designed to ensure that ample provision (to be decided by the Court) was made for a testator's dependents. Robert McNab, a Liberal of Mataura, argued it was the

duty of any man to be just before he was generous, and to provide for those who were near and dear to him rather than that all should go to those far removed from himself. $^{69}$

Others echoed this sentiment. Charles Hall of Waipawa also suggested a sense of duty, claiming it was an 'improper thing that any law should allow a man, in leaving an estate, to neglect to provide for his wife and children after his death. ${ }^{70}$ While the majority of the debate framed the issue in such terms, there were two notable exceptions. Josiah Hanan,

\footnotetext{
${ }^{68}$ As Chapter one has demonstrated, the wealthy in Wairarapa were exclusively of the lower and middle classes and almost entirely British.

${ }_{69}$ New Zealand Parliamentary Debates: Legislative Council and House of Representatives, vol. 113, August 16September 13, 1900, pp.503-504.

${ }^{70}$ Parliamentary Debates, p.504.
} 
of Invercargill noted that widows deserved some benefit for their role in accumulation. ${ }^{71}$ In the Legislative Council's debate of the same bill, Jeremiah Twomey suggested that children too, contributed to the accumulation of capital:

It is astonishing that such an outrageous wrong can be done as that a man can will away his property, which the wife and children in all probability assisted him to accumulate- that he can by one stroke of the pen transfer that property to others, and leave his wife and children penniless. ${ }^{72}$

In emphasising the involvement of the whole family Hanan and Twomey were, however, in the minority. Overwhelmingly, it was a sense of duty that was considered to drive testators' decision-making.

The lack of coherence between public discussions of testamentary practice and the realities of private decision-making is striking; duty was much less important to testators than the rhetoric would suggest. Those testators who disinherited children tended to still leave them a small inheritance, suggesting that the rich might have been influenced, at least in part, by a sense of duty. Beyond this, however, testators were governed by principles other than duty. Certainly, a belief in simple duty does not explain why sons were more likely to inherit absolutely, nor why daughters (and sons) received much greater shares than their mothers.

Wealthy testators in Wairarapa planned for the future. The favouring of daughters over widows has already been cited as evidence of this, but testators also demonstrated the importance of planning for the future in their bequests to grandchildren. Edwin Meredith, for example, dictated that

During the minority of my grandson Meredith Heaton Rhodes my trustees shall apply the whole or such part or parts as they shall think for of the annual income (derived from his share)...towards his maintenance education or support. ${ }^{73}$

Five $(8.5 \%)$ Wairarapa testators made bequests like Meredith's to their grandchildren.

Another way of looking after grandchildren was in the provision for the death of a child, in which grandchildren would receive their deceased parent's share. Generally,

71 Parliamentary Debates, p.505.

72 Parliamentary Debates, p.616.

${ }^{73}$ Meredith Probate File, 1907, Series 18575, Accession W5447, No. 153, ANZ/W. 
bequests to grandchildren were slightly more likely to be given to the children of daughters, perhaps suggesting that where the testator had little scope for on-going economic involvement (the daughter's economic fortunes often being dependent on a husband's) testators were more inclined to ensure their grandchildren were looked after. In many cases, a daughter's share would be for her sole and separate use (meaning a husband could not touch it). When both provisions were made in the same will, a daughter's inheritance would go straight to her children (instead of her husband) upon death. Bequests that thought so far ahead suggest that wealthy testators were not only interested in setting up their children in business, they were attempting to exert as much influence as they could on their family's long-term economic future.

Occasionally, childless testators proved the importance of future generations by favouring nieces and nephews over brothers and sisters. Robert Cockburn, the childless farmer who, as discussed, left substantial property to his nephew Alexander Mutrie, highlights this. When Cockburn died in 1902 he still had living siblings but chose to leave his money to his nieces and nephews, even choosing to provide for the children of some of his nephews. To Cockburn, it apparently made little difference whether he was leaving property to his nephews or nieces, or those of his late wife Jemima- he left both his smallest and largest absolute bequests to two of his wife's nieces. ${ }^{74}$ Most importantly, Cockburn was providing for future generations.

Dividing an estate was not just about thinking about the family's future, it was about providing widely; equality was an important guiding principle for wealthy Wairarapa testators. As we have already seen, equality certainly occurred; sons and daughters often received 'substantially equal' bequests. ${ }^{75}$ More than that, however, equality was conscious: it appears to have been at the forefront of Wairarapa testators' minds at the end of their lives.

Most often, the importance of equality was expressed simply. Thomas Brown (d.1910, $£, 10,100)$ was one the many who employed the simple language of equality:

\footnotetext{
74 'The Passing of a Pioneer', Wairarapa Daily Times, 12 February 1906, p.5, Cockburn Probate File, 1906, Series 18575, Accession W5447, No. 132, ANZ/W.

${ }^{75}$ Further, even if sons and daughters received different bequests, a son's bequest was usually equal to that of his brother (and the same for a daughter and her sisters).
} 
I direct that my trustees shall stand possessed of the balance of the proceeds of my said real and personal estate and also of the capital sum to be invested as aforesaid upon trust for all my children who being a son or sons shall attain the age of twenty one years or being a daughter or daughters shall attain that age or marry under that age share and share alike equally to be divided between them. ${ }^{76}$

Another, Henry Holmes:

I declare that after the death or second marriage of my said wife my trustees shall hold my trust property upon trust for my children living at my death...in equal shares as tenants in common (if more than one). ${ }^{77}$

The constant appearance of these boilerplate phrases_-'share and share alike' and 'tenants in common'-forms a partible refrain in the testamentary records of the Wairarapa rich. The wealthy's persistent employment of such phrases underscores the importance of equal division to the rich.

In other cases, the specificity of bequests suggests a keen sense of fairness. The pastoralist Charles Harris decided that a sum should be invested on behalf of each of his children. While daughters Elizabeth and Eliza received $£ 12,000$, son Abraham and daughter Mary received $£ 8,549$, daughter Sophia received $£ 8,542$ and son Thomas received $f 7,250 .^{78}$ The fact that there appears to have been a clear 'ceiling' $(£, 12,000)$ and various levels below that, suggests that there was a reservoir of funds out of which Harris's children could extract financial support during his lifetime; some of the Harris children had apparently required more of their father's money than others. This understanding is supported by the final clause in Harris's will, which stipulated that, should his estate prove insufficient, the amounts given to each child should be reduced by 'a sum equal to one-seventh of the total deficiency.'

Often, testators made it clear that children had already received their 'fair share.' Henry Jackson wrote 'I hereby declare that my daughters Eliza... and Annie have been provided for in my lifetime and take no benefit. ${ }^{79}$ John Groves bequeathed his estate to his children to be split equally, but added that son John and daughter Grace should receive

\footnotetext{
${ }^{76}$ Brown Probate File, 1910, Series 18576, Accession W5447, No. 7/10, ANZ/W. Emphasis added.

${ }^{77}$ Holmes Probate File, 1911, Series 18576, Accession W5447, No. 20/11, ANZ/W. Emphasis added.

${ }^{78}$ Harris Probate File, 1913, Series 18576, W5447, No. 7/13, ANZ/W.

${ }^{79}$ Jackson Probate File, 1905, Series 6029, No. 9435, ANZ/W.
} 
only token amounts ( $£ 200$ and $£ 100$ respectively) given that they had 'received a fair share of my estate during my lifetime. ${ }^{80}$ The farmer William Smith wrote: 'I make no bequest to my son David as he has already been provided for in my lifetime nor to my son William who has already received considerable sums from me. ${ }^{81}$ Smith's two sons had evidently received 'enough' from their father-the majority of his estate went to his remaining children.

The dedication to equal division of estates-also known as partible inheritance-is a characteristic that belonged firmly to the middle classes. The influential Leonore Davidoff and Catherine Hall argued in 1987 that 'the middle class favour partible inheritance, a roughly equal division of property between all dependents' whereas 'male heads of landed families thought in dynastic terms, believing the intact estate to be the basis of power and status. ${ }^{82}$ The importance of this identity has also been established empirically, Davidoff and Hall note

The difference in the two patterns is strikingly illustrated by the change in inheritance practices of men in the judiciary. As Duman has shown, as the social background and identification of this elite group shifted away from the gentry and towards a more codified legal profession, so they began to leave their substantial properties away from a single heir, usually the eldest son, to their wives and children equally. ${ }^{83}$

Other historians analysing inheritance patterns have found that the professional classes have been far more likely to favour partible inheritance than the landed class. Rubinstein found that 'equal or nearly equal division among the heirs of the top business or professional wealth-holders was very generally the rule. ${ }^{84}$

Partible inheritance relates to the economic life of the middle-class family in several ways. Most importantly, spreading a fortune meant spreading risk. If one member of the family failed there would be a larger 'safety net' to soften the blow. ${ }^{85}$ Failure of business

\footnotetext{
${ }^{80}$ Groves Probate File, 1906, Series 18575, Accession W5447, No. 129, ANZ/W.

${ }^{81}$ Smith Probate file, 1903, Series 6029, Accession W3265, No. 8180, ANZ/W.

82 Davidoff and Hall, Family Fortunes: Men and Women of the English Middle Class 1780-1850, (Chicago, 1987), pp.206-207.

83 ibid.

${ }^{84}$ Rubinstein, p.134.

${ }^{85}$ Morris has a particularly useful discussion of the importance of partible inheritance to the middle classes, Morris, Men, Women and Property, pp.114-119.
} 
was a real threat to the wealthy in Wairarapa-several suffered failure before succeeding. ${ }^{86}$ If everybody in the family had a small share of the fortune, they might be able to prop up a family member suffering temporary setback. By splitting an estate into smaller shares, a testator also encouraged enterprise. This was an argument employed by Adam Smith in Wealth of Nations. Smith argued that an inheritance that had been split was less likely to support the accumulation of passive profit. This would provide children with the encouragement to work for themselves, a value central to success under capitalism. ${ }^{87}$

A desire to leave a legacy also motivated wealthy Wairarapa testators. Most often, legacy bequests were personal and private-concerned with either creating or propagating a legacy within the family. ${ }^{88}$ Several left jewellery. The lawyer, Charles Gawith bequeathed to his son Samuel Roy his 'watch and plain gold chain' and to his son Alan 'my gold chain with guinea attached also my arm chair. ${ }^{, 89}$ Pastoralist Edwin Meredith left two pianos to his daughter Rosina and a writing table to each of two other daughters. ${ }^{90}$ Charles Vallance (d.1882, $£_{19,123)}$ was particularly concerned with his legacy; he left $f^{20}$ to each of his stepchildren to purchase mourning rings. ${ }^{91}$ Edward Maunsell requested that a section of his land be turned into a 'family burial ground... properly enclosed and fenced to exclude animals... and further that a sum of $£ 15$ be spent on headstone and bricking in my grave and other necessary work.' Maunsell further requested that he be buried 'no deeper than four feet. ${ }^{92}$

The bequest of meaningful objects has been seen as most common in women's wills. ${ }^{93}$ Historians agree that women were more likely to leave meaningful objects to others in their wills, but are less certain on why. In 1984, Suzanne Lebsock argued that women's

\footnotetext{
86 Pierce Cotter (d.1894, $f, 18,116)$ was one of those who endured failure before finding success. Cotter's obituary recorded that he had suffered business failure because of an 'overenthusiastic devotion to flax.' 'Local and General', Wairarapa Daily Times, 29 June 1894, p.2.

${ }^{87}$ Morris, Men, Women and Property, p.115.

88 Testators might have also left public legacies through charitable bequests, but these were rare. The few charitable bequests that were made by the Wairarapa wealthy will be discussed in Chapter three, which looks at the wealthy's public involvement.

${ }^{89}$ Gawith Probate File, 1911, Series 18576, Accession 5447, No. 36/11, ANZ/W.

${ }^{90}$ Meredith Probate File, 1907, Series 18575, Accession W5447, No. 153, ANZ/W.

91 Vallance Probate File, 1882, Series 6029, Accession W3265, No. 1870, ANZ/W.

${ }^{2}$ Maunsell Probate File, 1908, Series 6029, Accession W3265, No. 11159, ANZ/W.

${ }^{3}$ Of the women studied here, only Harriot Riddiford made such a bequest, leaving each of her children specific objects including cutlery, furniture and art. Riddiford Probate File, 1892, Series 6029, Accession W3265, No. 3739, ANZ/W.
} 
tendency to give meaningful items was a product of a distinct value system that promoted 'personalism'. ${ }^{94}$ More recently, Morris has seen women's tendency to bequeath significant personal items as a product of women's world: 'the decision to nominate 'things' in a will was influenced by gender and individual preference. ${ }^{95}$ But although legacy bequests appear to have been for personal reasons, they still had an economic function. As Wyse notes, 'things' have 'emotional attachments, representing personal relationships or events', but also 'the process of transferring ownership of objects creates networks of trust and reciprocity' which are important in capitalist society. ${ }^{96}$

It is impossible to know exactly what individuals meant to communicate with the bequest of meaningful objects but Lebsock's argument seems insufficient. Material bequests were not restricted to women entirely; men left objects too, even if they did so less often. ${ }^{97}$ Of course, objects were symbols of personal preference, but personal preference does not exist in a vacuum-it is shaped by gender, class and other factors. Objects, then, were loaded with meanings, whether the testator meant it or not.

Strategising the future, providing equal opportunities and leaving a legacy were all important to the Wairarapa wealthy_but it was not all about communicating one's own values; the testamentary moment was also seen as an opportunity to inculcate future generations with the tools to survive in a capitalist society. These motives situate the Wairarapa wealthy in the middle classes and demonstrate that, at least in private, the rich functioned as they always had.

\section{Bequeathing Values}

There was no legacy so rich as an honest work ethic. While testators ensured their children all inherited ample property, they also bequeathed a belief in the importance of hard work, an important value to capitalist societies.

Didactic bequests could be either encouraging or corrective. John Rayner (d.1903, $£, 17,432)$ wanted to make sure that he reminded his sons of his own hard work: 'as to my

\footnotetext{
${ }^{94}$ Suzanne Lebsock, The Free Women of Petersburg: Status and Culture in a Southern Town, 1784-1860, (New York, 1984) p.xix.

${ }^{95}$ Morris, Men, Women and Property, p.247.

${ }^{96}$ Wyse, p.68.

${ }^{97}$ Morris notes that when men bequeathed items, 'they named a more limited number of items and did so for very specific reasons.' Morris, p.248.
} 
prizes and medals that I have won for stock to all my sons to be drawn for by lots. ${ }^{98}$ While Rayner perhaps sought to encourage his sons by leaving them his medals, others used the testamentary moment as an opportunity for a more punitive approach. When George Luxford (d.1905, £33,880) wrote his first will in 1881 he intended to divide his estate simply. His property would be split between his four sons-William, Samuel, Henry and Frank-equally. Five years later-1886-Luxford had changed his mind, writing in a codicil to his will: 'I revoke the appointment of my son Henry Jabez Luxford as an executor and trustee of my will and I revoke all devises and bequests by my will made to the said Henry Jabez Luxford.99 Henry was instead given a $£, 500$ payment and the remainder of Luxford's estate was split three ways. Family legend has it that Luxford was disinherited because of alcoholism, although this is difficult to verify. ${ }^{100}$ Frederick Monckton made a similar decision with his son Frank who was 'always in trouble.,101 While Frank's brothers Leslie and Owen were set up on farms of their own and received absolute bequests as discussed, Frank's share was held and invested on his behalf, with the income being directed to him for the duration of his life.

The 'rent-to-widow' bequest was the most common method of bequeathing values. In numerous cases, wealthy Wairarapa testators left properties to their sons or daughters with the condition that the child should pay rent to the testator's widow for the duration of her widowhood or life. Jacob Matthews (d.1908, f20,719) at Opaki split his estate equally between his son Alfred, and his daughter Mary. The Matthews children were given blocks of land of roughly equivalent size (as mentioned, Mary's husband, Charles Wilton was already farming a block of Matthews's land) but neither received their land outright. Both Alfred and Mary were to make yearly payments of $£ 30$ to 'my dear wife Ann.102 Only after Ann's death would Alfred and Mary take ownership of their respective blocks. Hart Udy made a similar bequest, leaving all his Greytown land (seven acres) to his son, who would

\footnotetext{
${ }^{98}$ Rayner Probate File, 1903, Series 6029, No. 8638, ANZ/W.

${ }^{99}$ Luxford Probate File, 1905, Series 6029, No. 9405, ANZ/W.

100 Carole Von Grondelle, Angel of the Anzacs: The Life of Nora Luxford, pp.37-38 George Luxford's will records Henry as living in South Africa. The singularity of this case suggests that Henry was intentionally written out of his father's will. It was not uncommon for one son or daughter to receive substantially less than others, but in such cases testators tended to explain that their son had received their fair share during the testator's life (as previously discussed).

101 As recalled by Frank's sister Lorna in Joblin, pp.100-101.

102 Matthews Probate File, 1908, Series 18575, AccessionW5447, No. 174, ANZ/W.
} 
pay an annuity of $£ 26$ to his mother for the duration of her widowhood. Four other sons would receive substantial farms with similar agreements, paying their mother annuities that varied between $£, 100$ and $£ 300$ in quarterly payments for the duration of her widowhood. 103

Farmer John Rayner was particularly adamant that his children should not receive anything for free. His will made the following bequests.

As to all that piece or parcel of land situate in the west Taratahi in the said County of South Wairarapa containing seven hundred acres... In trust for my son Benjamin Richard Rayner absolutely subject to the payment by my said son Benjamin Richard Rayner to my trustees of the sum of one thousand four hundred pounds $(£, 1400) .{ }^{104}$

As to all that piece or parcel of land...containing about four hundred (400) acres subject nevertheless to the mortgage for eight hundred pounds $(£ 800)$ now subsisting thereon for my son William Hewison Rayner absolutely.

And as for the residue of the Rayner estate

To divide the same between and amongst my five sons such aforesaid residue to be divided between my said sons to each in proportion to the amount of rent paid to me respectively by them.

Clearly, Rayner was reluctant to give his property away. A keen sense of equality and a belief in reciprocity pervades his will.

Remember, testators might easily have provided their children with property and their widow with an annuity without stipulating that the child should pay their mother. The rentto-widow bequest served several functions; it reminded the next generation that nothing would be given to them without their working for it. The bequest also strengthened familial links; by ensuring that the family remained obligated to one another, the testator may have hoped to protect the family unit.

The importance of hard work, thrift and enterprise to the Wairarapa wealthy informed their testamentary practices. When considered alongside the importance of partible division of estates to encouraging capitalist enterprise, however, the lessons taught by the Wairarapa testators take on greater significance, underscoring the way in which the Wairarapa wealthy continued middle-class traditions in private.

\footnotetext{
${ }^{103}$ Udy Probate File, 1906, Series 6029, No. 9779, ANZ/W.

104 Rayner Probate File, 1903, Series 6029, No. 8638, ANZ/W.
} 


\section{Conclusion}

This chapter has analysed testamentary practices in order to focus on the private lives of the rich. By following traditionally capitalist testamentary patterns, the Wairarapa wealthy reflected their origins in the British middle classes. Clearly, private life was about economic survival.

Testamentary practices in Wairarapa also demonstrate both consistencies with and departures from the South Island as outlined by McAloon. Most importantly, future generations were favoured over widows, and estates were divided equally between children. This confirmation of McAloon's analysis is significant if unsurprising. It demonstrates that elements of testamentary practices (and associated values) transcended the North Island/South Island and urban/rural divides. It also demonstrates that even when land and farming were almost everything (in terms of prospects for accumulation), estates still tended to be broken up evenly.

There are also notable differences between Wairarapa and Canterbury and Otago. While widows everywhere tended to receive less than their children in their husbands' wills, Wairarapa widows were less likely to receive their inheritance absolutely and were less likely to be named as an administrator of their husband's estate. These findings are consistent with Stephanie Wyse's conjecture: rural areas were more restrictive of women's economic agency than were urban areas. 



\section{Chapter Three: 'A keen interest'?-The Wairarapa Wealthy in Their Community}

The Wairarapa wealthy were not engaged in public matters. This is particularly surprising given that newspaper obituaries consistently framed wealthy settlers as publicly-minded; Henry Holmes (d.1911, £63,959), for example, 'took a keen interest in Wairarapa affairs' while John Purvis Russell (d.1906, £46,632) 'took a keen interest in the general welfare and the public affairs of his district. ${ }^{1}$ Charles Vallance $(\mathrm{d} .1882, £ 19,123)$ received even higher praise:

The number of offices he has filled in this district at various times would be a record of almost every local institution in the Wairarapa, and in everyone he was conspicuous by a conscientious attention to all business which he took in hand; and earnest desire to promote the welfare of the district, and an excellent judgment. ${ }^{2}$

When writing about those who did not take active roles, obituarists offered excuses and explanations. The inactivity of Masterton lawyer Charles Gawith (d.1911, £22,876) was forgiven: 'he did not take a prominent part in public affairs, but in private life he had a host of friends to who he was endeared by his culture and his charming personality." William Lucena $(\mathrm{d} .1897, \ldots 56,017)$ was 'prevented by deafness from taking an active part in political matters,' while John Morris (d.1906, £22,811) was simply 'of a retiring disposition' and so 'never took any part in public affairs. ${ }^{4}$ The disconnect between these obituaries and the evidence of actual involvement is striking; this chapter demonstrates that the wealthy were not very involved in public life.

First, this chapter explores types of involvement, demonstrating that 'developers' and 'squires' - terms commonly used to describe ways in which wealthy individuals could 'develop' their community—were less common in Wairarapa than in the South Island; here, development was more likely to be associational than individual. Second, this chapter

\footnotetext{
1 'The Good Times Coming', Wairarapa Daily Times, 22 September 1882, p.2; 'Mr. John Purvis Russell, Wairarapa Daily Times, 2 March 1906, p.5.

2 'Obituary', Dominion, 28 April 1911, p.5.

3 'Death of Mr Gawith', Wairarapa Daily Times, 14 November 1911, p.5.

4 'Death of Mr. W. L. Lucena', Hawera \& Normanby Star, 18 February 1892, p.2; 'Mr John Morris', Obituary, Wairarapa Daily Times, 1 June 1906, p.5.
} 
uses institutional roles to systematically measure the extent of public involvement, demonstrating that significant public roles tended to be occupied by townspeople (who, most typically, were not the wealthy). Instead, wealthy pastoralists fostered their own communities at home on the run, adopting the paternal managerial style most commonly associated with urban capitalists. Finally, this chapter discusses charity's non-importance to the Wairarapa wealthy. Wealthy men were apparently unwilling to become involved in (or make contributions to) charitable works-certainly they were less involved than the wealthy in Britain.

The wealthy's lack of involvement is significant for two reasons. First, it extends and problematises existing research. While the wealthy in both the North Island and South Island were not very involved in public life, individual development was much less common in Wairarapa than elsewhere, challenging the importance of existing conceptions of development. Further, while the paternalism of urban factory owners has been emphasised elsewhere, Wairarapa runholders demonstrated a similar attitude toward their employees. Second, the wealthy's lack of involvement represents a departure from the traditions of their origins. The Wairarapa wealthy's disinclination to participate in charitable giving demonstrates that while the private life of successful New Zealand capitalists reflected the group's origins, they began to reimagine their public function.

\section{Types of Involvement}

Broadly speaking, historians have seen wealthy individuals as relating to the development of their community in one of two ways: as either 'developer' or 'squire'. The main difference between the terms is in the types of improvements they provided; whereas developers made economic contributions_roads, bridges or mills_-squires were defined by the provision of largesse. ${ }^{5}$ The importance of these terms to existing discussion of

\footnotetext{
${ }^{5}$ For a full discussion of these terms see McAloon, No Idle Rich, pp.143-149. The 'developer' is an evolution of the 'booster' - a popular figure in histories of former British Colonies, and one which was first used in the New Zealand context by David Hamer in 1979. Although the practice of boosterism has typically been seen as one of advocacy rather than action, Hamer argued for an understanding of the booster as a practical individual. McAloon has favoured the term 'developer', avoiding the association of the term 'boosterism' with more vocal activity. David Hamer, 'Towns in Nineteenth-Century New Zealand', New Zealand Journal of History, vol. 13, 1979 pp.5-24. Later expanded upon in David Hamer, New Towns in the New World: images and perceptions of the nineteenth-century urban frontier, (New York, 1990) See Hamer, 'Towns in Nineteenth Century New Zealand' for a discussion of the international scholarship on boosterism.
} 
wealthy public involvement warrants their inclusion here, but analysis quickly demonstrates that in Wairarapa, individual development by developers and squires was less important than associational development.

There were few individual developers in Wairarapa but Alfred Renall (d.1902, $f^{26,601)}$ best fits the mould. Already a member of the Provincial Council for the Hutt, Renall moved the remains of his mill (destroyed in an 1858 flood) to Masterton. ${ }^{6} \mathrm{He}$ established the Masterton Road Board, becoming both chairman and engineer, in which capacity he was responsible for the construction of local bridges and roads. The Cyclopedia records that

Mr. Renall has been a prominent figure in Masterton for nearly thirty years; he has been forward to help every good cause, and has enjoyed a large share of popularity, which he has richly merited.

Bagnall adds that Renall

Exerted an influence far beyond his relatively brief leadership in public life. To record that he was a representative of the Hutt and later of Wairarapa in the House of Representatives for eight years, a member of the Provincial Council for seven years, a two term mayor of Masterton and a one term chairman of the Trust Lands Trust is to give an inadequate framework for his achievement. ${ }^{8}$

Although no other individual among the Wairarapa rich played quite the same role as Renall, there were other developers. While Renall operated in Masterton, Greytown's equivalent was the sawmiller Hart Udy (d.1905, £23,958). Udy supervised the construction of the town's first road, was a member of the Road Board and the Waiohine River Board, and was councillor for Greytown, becoming mayor in 1884 . $^{9}$ There were also others in Masterton who occupied less conspicuous roles than Renall. The storekeeper and farmer William Lowes (d.1901, $£ 11,635)$ was the chairman of the Masterton Trust Lands Trust, a member of the Agricultural and Pastoral Association and a director of the Masterton Building Society. ${ }^{10}$ The blacksmith and farmer Farquhar Gray (d.1894, £16,145) 'always

\footnotetext{
${ }^{6}$ Renall had been involved in the Small Farms Association's original petition to governor George Grey.

7 'Alfred William Renall', Cyclopedia, Wellington, p.939.

${ }^{8}$ Bagnall, p.309.

9 'Mr Hart Udy, J.P.,' Cyclopedia, Wellington, p.875.

10 'The Late Mr Lowes', Wairarapa Daily Times, 15 July 1901, p.3.
} 
took the greatest interest in the welfare of Masterton. ${ }^{11}$ Gray, like Lowes, was a member of the Masterton Trust Lands Trust as well as being a member of the Borough Council.

There was only one who fit the mould of the squire in Wairarapa: John Martin (d.1892, f,92,358), founder of Martinborough. Martin purchased the 33,346-acre Huangarua estate from former premier G. M. Waterhouse in 1879, soon publicising his intention to subdivide and sell small farms, as well as 593 town sections around the existing Southern Lakes town Wharekaka (which would be renamed Martinborough). ${ }^{12}$ Despite inauspicious beginnings (the initial auction failed) Martinborough eventually prospered. Martin had the town square laid out in the shape of a Union Jack and named the central streets after famous locations he had visited on a recent trip. There was a sense of indebtedness to Martin in contemporary editorials:

It is impossible for a more judicious site to have been selected, and surrounded as it is by a valuable agricultural district, we are not wrong in saying that the Hon. John Martin deserves the thanks of the colonists for placing at their disposal so valuable an estate...if there is any truth in the statement that the people want land, all we can say is that Mr. Martin is affording them an excellent opportunity of obtaining it. ${ }^{13}$

John Martin, however, was in a minority of one-very few in Wairarapa took responsibility for individual development of towns.

The genesis of the Small Farms towns limited opportunities for private involvement in development. In his early work on the development of New Zealand towns, David Hamer argued that the developer 'precedes the formation of a 'community' and is in effect the substitute for one,' but in both Greytown and Masterton the towns' geneses as Small Farms Association settlements meant that this ordering of events was subverted. ${ }^{14}$ That is, as towns founded by an existing community (albeit a community formed for the very purpose of creating a settlement) Masterton and Greytown did not require the classic developer to act as a substitute for community and a leader of 'progress'. The Small Farms Association was a community invested in the economic success of the town and tended to approach development democratically. The legacy of this foundation is on-going. In 1867,

\footnotetext{
11 'Death of Mr Farquhar Gray', Wairarapa Daily Times, 17 January 1894, p.2.

${ }^{12}$ McIntyre, pp.109-110.

13 'Martinborough', Evening Post, 20 November 1879, p.3.

${ }^{14}$ Hamer, p.15.
} 
unsold Small Farms land was combined and two trusts were set up to deal with the income. The Masterton and Greytown Lands Trusts are the legacy of the towns' democratic origins. ${ }^{15}$

In the Trust towns, the Trust was both developer and squire. The (voluntary) role of the Trust included provisions that wealthy individuals in squire-towns might have made. At their fourth meeting, the Masterton Trust Lands Trust made a first donation to the town: the construction of a Literary Institute (which would later become the town hall). ${ }^{16}$ The trust made provision for a variety of improvements of varying economic value: several churches (of different denominations), a school, the post office and courthouse as well as a hospital (although this land proved unnecessary). ${ }^{17}$ The provision of some of these institutions replaced the largesse of the squire, but the trust was also concerned with improving the town in a manner similar to that typically undertaken by a developer, being involved in improvements of clear economic value. ${ }^{18}$ The Trust donated land to widen Masterton's Dixon and Chapel streets and also contributed significant capital towards the project. $^{19}$

The Wairarapa trusts complicate existing research on developers and squires. The importance of associational development (rather than that by individuals) in Wairarapa is a significant point of difference between Wairarapa and the Southern regions. It demonstrates that while developers and/or squires may have been a necessary feature of a town's advancement (after all, an action requires an actor), these roles were not necessarily carried out by individuals.

\footnotetext{
${ }^{15}$ It should be noted that this legacy was an accident. If more sections had sold at the initial auctions, there would not have been so much property left over for the Lands Trusts. Further, the Greytown Lands Trust played a smaller role than did the Masterton Trust, due to a relative shortage of unsold sections. Bagnall, pp.521-531.

${ }_{16}$ Alan Henderson, Fortuitous Legacy: The Masterton Trust Lands Trust 1872-1997, (Masterton, 1997), p.98.

${ }^{17}$ Henderson, p.99.

18 Of course, potential developers could still become involved in their community within the Trust, and several of the wealthy occupied such roles. Most often, those involved in the Small Farms Association continued their involvement. Farquhar Gray, William Lowes, Alfred William Renall all featured prominently. ${ }^{19}$ Henderson, p.99.
} 


\section{Extent of Involvement}

Obituaries and other biographical information demonstrate that there were different ways in which the wealthy could be active within their community, but a more systematic analysis of their function gives us a wider view of the extent of involvement. This section presents an analysis of official public roles, indicating that the Wairarapa wealthy were not very involved in public life. A look at who did occupy these public roles explains the wealthy's exclusion by highlighting divisions between the rural rich and the growing towns. Although one did not have to join institutions to be active in the community, and that involvement was in many cases contingent on election, the occupation of public positions has the advantage of being widely reported. Figure 13 demonstrates the extent of public involvement.

Obviously, the information presented in Figure 14 is incomplete. Only those whose public roles are known have been tabulated; for several of the wealthy there was insufficient biographical information to tell whether they occupied a position. In some instances, individuals almost certainly occupied unknown positions. The best example of this is Anders Andersen (d.1907, £15,646), whose obituary (the only piece of biographical information available) records simply that he was a 'prominent worker in public matters'-no specifics are offered. ${ }^{20}$ Where insufficient biographical information has been an issue, this has been noted so as to distinguish cases of 'lack of information' from those in which it is reasonably clear that an individual positively did not occupy a public role. Those not included in the final analysis have been removed from the above table. Women have also been removed because of structural barriers to their occupation of such roles. ${ }^{21}$ Because women had little or no opportunity to involve themselves in local institutions (of the type recorded above), their lack of involvement is not read as an act of self-expression in the same way as men's.

\footnotetext{
20 'District News', Evening Post, 20 April 1908, p.9.

21 With the exception of Hanna Card, whose legacy of $£, 150$ to the Committee of the Catholic Church, Featherston qualifies her as a 'churchgoer'. Still, Card's lack of involvement in other community groups has not been counted for the reasons stated above.
} 
Figure 14: Community Involvement of Wairarapa Wealthy

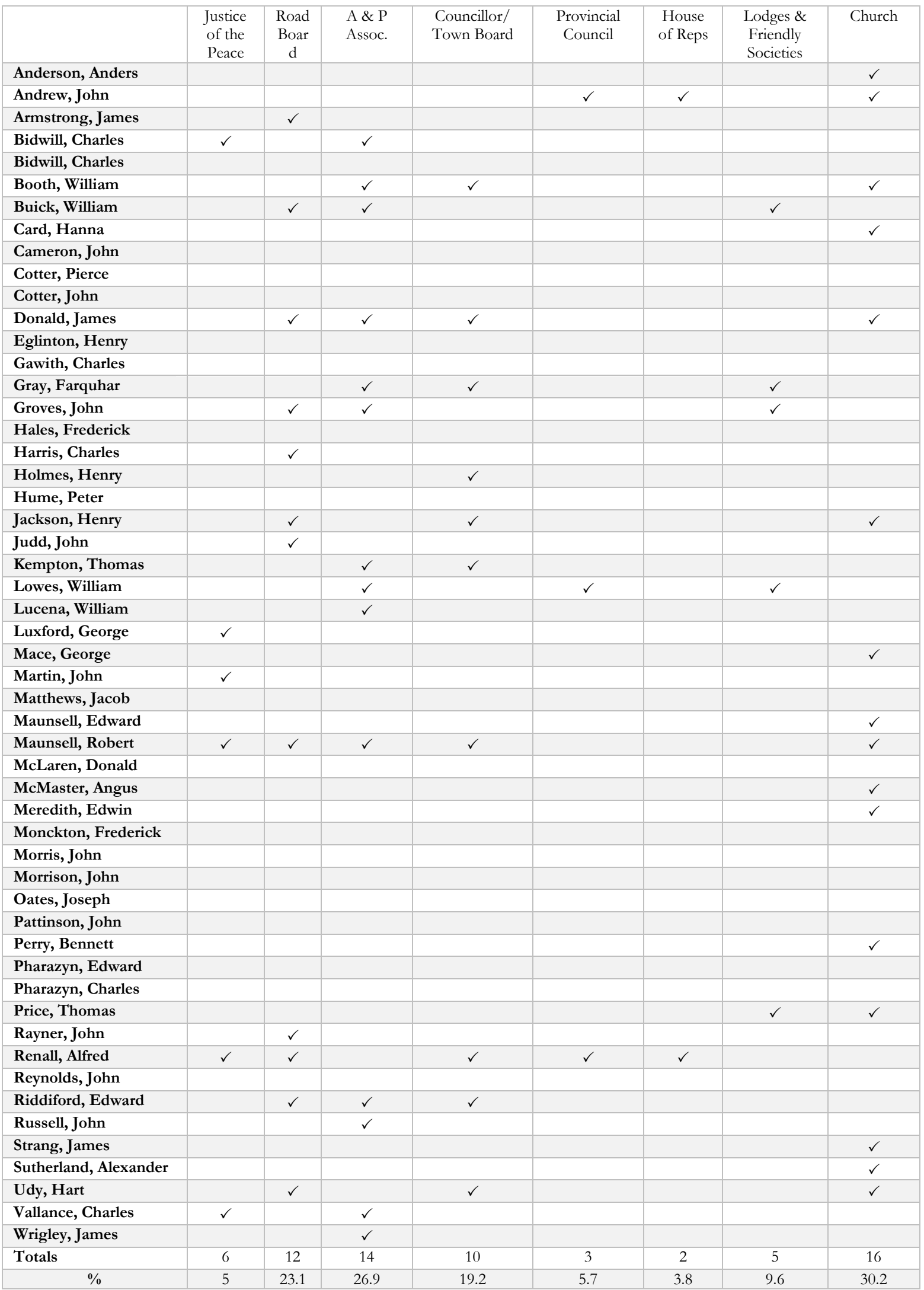


It is immediately obvious that most of the wealthy were involved in some sort of community activity but filtering out 'minor' community roles leaves a different impression. A total of fifty-two of the Wairarapa rich have been included in the above table and of these, thirty-four $(65.4 \%)$ occupied one of the tabulated public roles, leaving eighteen $(34.6 \%)$ who had no known role in the community. Although at first glance this seems like widespread involvement, there are two factors to consider. First, those about whom there is little biographical information available were probably less likely to have occupied public roles, and so their removal overestimates the wealthy's public involvement. ${ }^{22}$ Second, several of the individuals in the table only occupied minor roles; those with the Agricultural and Pastoral (A\&P) Association or the Road Board. ${ }^{23}$ Discounting those who had no involvement in public institutions beyond these two entities (as well as churchgoers and lodge members) moves eight individuals from the 'involved' category to 'not involved', giving us only seventeen (33\%) involved and thirty-five (67\%) with no involvement.

Although churchgoing and lodge or friendly society membership represented a form of involvement, they were less the products of public-mindedness than were other roles tabulated in Figure 14. Of the fifty-three about whom sufficient biographical material exists, sixteen $(30.2 \%)$ were actively involved in local churches, whether through bequest to said church, or through 'active membership' described in obituaries and other biographical sources. This proportion is very close to that found by McAloon in the South Island. ${ }^{24}$ Lodge or friendly society membership was rare among the wealthy in Wairarapa. Only five $(7.7 \%)$ of the cohort were found to have an affiliation with a lodge. The significance of these memberships is murky and there is not space here for an extended

\footnotetext{
22 Assuming that occupation of such roles boosted an individual's chances of prominence in the historical record.

${ }^{23}$ This is not without some consideration. Besides the fact that involvement in A \& P associations and Road Boards was less taxing on the individual than were other positions, we are here interested in community involvement that did not directly benefit the individual. Agricultural and Pastoral associations were not designed to benefit anyone other than farmers. The exclusion of Road Boards is justified by their focus. According to Bagnall, the men who sat on Road Boards were 'enmeshed in the nascent differences of outlook between town and country.' (Bagnall, p.388) The inclusion of these categories in the initial analysis demonstrates that the wealthy were the happiest to 'give up' their time for positions that benefited them most immediately.

${ }^{24}$ McAloon, p.153 McAloon notes that best estimates indicate the wealthy were probably slightly overrepresented amongst churchgoers.
} 
exposition; it is sufficient to note that church membership could be motivated by a mixture of self-interest, a sense of tradition and genuine piety. Whatever the reasons, churchgoers and lodge members were removed from the processes of development and so both have been eliminated from the final 'involved' category along with A\&P Association membership and involvement in Road Boards. The frequency with which churchgoing appears as a wealthy individual's only community involvement in the above table is telling-nine of sixteen churchgoers had no other community involvement.

Making these exclusions leaves those involved in local government, which is perhaps the most effective way of systematically analysing community involvement. Although those holding local positions were often elected (by property owners), officeholders had arguably demonstrated the greatest dedication to the advancement of the community. ${ }^{25}$ Involvement in local government at the council level indicated a commitment to the economic advancement of the community and inasmuch 'could in some respects be described as an institutionalisation of the development ethic. ${ }^{26}$ It is immediately clear that very few of the wealthy served in these positions-nine of the wealthy $(17 \%)$ served as local councillors, and there were only two (4\%) mayors among the rich. McAloon records that in the South Island, '36.8\% were members at one time or another of country, borough or city councils, harbour or road boards or school committees. ${ }^{27}$ In Wairarapa, the figure for these same categories was relatively similar, at $32.7 \%$. While the levels of participation are by no means low (certainly the rich were far over-represented in these roles) local government seems to have been less oligarchic than might be imagined.

Why were the wealthy not involved in public affairs? One answer might be that they simply identified with a community beyond Wairarapa, but this is quickly disproven. The inclusion of the Provincial Council and House of Representatives in the above table demonstrates that the wealthy were not withholding themselves from local politics in

\footnotetext{
${ }^{25}$ At the least, there is a positive relationship between community involvement and the probability of being elected.

${ }^{26}$ McAloon, p.147.

27 ibid.
} 
order to focus on national affairs. Among the Wairarapa wealthy, only three individuals occupied these nationally-focused roles.

Figure 15: Mayors in Masterton, Carterton and Greytown, 1877-1900

\begin{tabular}{|c|c|c|c|}
\hline Mayors $^{28}$ & $\begin{array}{l}\text { Where } \\
\text { Mayor }\end{array}$ & When Mayor & Occupation when elected \\
\hline R. G. Williams & Masterton & $1877-1878$ & Saddler \\
\hline D. McGregor & Masterton & 1878-1879 & Sawmiller \\
\hline E. Feist & Masterton & 1879-1880 & Storekeeper \\
\hline A. W. Renall & Masterton & $\begin{array}{l}1880-1881,1888- \\
1889\end{array}$ & Miller \\
\hline A. Bish & Masterton & $1881-1883$ & Jeweller \\
\hline W. Lowes ${ }^{29}$ & Masterton & $1883-1884$ & Storekeeper \\
\hline M Caselberg & Masterton & 1884-1887 & Factory owner/ businessman \\
\hline G. Heron & Masterton & $\begin{array}{l}\text { 1889-1890,1894- } \\
1896,1898-1899\end{array}$ & Corn Dealer \\
\hline G. A. Pownall & Masterton & $\begin{array}{l}\text { 1890-1893, 1898- } \\
\text { 1898, 1899-1902 }\end{array}$ & Solicitor \\
\hline R. Fairbrother & Carterton & 1887-1891 & Storekeeper \\
\hline A. Booth & Carterton & 1891-1892 & Farmer \& Sawmiller \\
\hline G. W. Deller & Carterton & 1892-1901 & Butcher \\
\hline T. Kempton & Greytown & 1879 & Farmer \\
\hline J. Smith & Greytown & 1879-1880 & Medical Practitioner \\
\hline H. Udy, senr. & Greytown & 1880-1881 & Farmer \\
\hline F. H. Wood & Greytown & $\begin{array}{l}\text { 1881-1884, 1885- } \\
\text { 1886, 1888-1889, } \\
\text { 1892-1893 }\end{array}$ & Auctioneer, Stock Agent \\
\hline H. Udy, junr. & Greytown & $\begin{array}{l}1884-1885,1886- \\
1888\end{array}$ & Sawmiller \\
\hline R. A. Wakelin & Greytown & 1889-1892 & Factory Owner \\
\hline J. D. Heagerty & Greytown & $\begin{array}{l}\text { 1893-1898,1899- } \\
1901\end{array}$ & Farmer \& Storekeeper \\
\hline H.S. Izard & Greytown & 1898-1899 & Solicitor \\
\hline
\end{tabular}

A systematic way of considering the reasons why the wealthy were not involved in public roles is analysing who did occupy these roles. An analysis of the local mayors' biographies-presented in Figure 15-offers an explanation (through contrast) for the wealthy's exclusion from local government. The regions selected here are those in which

\footnotetext{
${ }^{28}$ Bagnall lists Wairarapa mayors in the appendices to Wairarapa. The occupational information has been collated from other biographical sources-most often Cyclopedia entries. Bagnall, pp.536-537.

${ }^{29}$ In offering an occupational breakdown of Wairarapa mayors, occupation at time of election has been selected; William Lowes went on to become a farmer (and indeed is classed as one elsewhere in this study) but at the time of his election made his income as storekeeper and stock agent in Masterton.
} 
the wealthy might conceivably have been eligible for and interested in the mayoralty, and those for which the absence of wealthy mayors is therefore most telling. ${ }^{30}$

The results are striking; there is a clear occupational difference between the Wairarapa mayors and the wealthy testators. In Wairarapa, farmers made up a comfortable majority of the wealthy, but they made up a small minority of those elected to the mayoralty. Thomas Kempton, the first mayor of Greytown (and father of Thomas Kempton (d.1910, $£ 25,268)$ ) was the closest thing to a mayor who was an 'out and out' farmer-others listed as farmers above tended to have urban interests too. ${ }^{31}$ The numbers indicate clear barriers to farmers' involvement in the politics of the town: in a rural area in which farming wealth accounted for $71.8 \%$ of the wealthy, $80 \%$ of local mayors prior to 1900 made their money from non-farming enterprises.

Certainly by this measure the Wairarapa wealthy farmers had a disinclination to become involved in local government, but the feeling appears to have been reciprocated by at least some of the constituency. ${ }^{32}$ In 1883 , prior to the election of William Lowes as mayor of Masterton, an argument about the suitability of mayoral candidates flared up in the Wairarapa Daily Times. In particular, the newspaper suggested that as rural landholders, the mayoral candidates were poorly suited to look after the interests of Masterton. In response to a letter to the editor, the newspaper published a comment that 'Messrs Lowes, W. Beetham, McGregor and Chamberlain are considerable land holders, and we believe owe their return to their country and not to their town interests. We are not in the habit of promoting discord, but at the same time we do not see any advantage in ignoring plain palpable facts. ${ }^{33}$

One of the problems was that pastoralists were not seen as making the most efficient use of the land, leading to a lack of jobs for townspeople. One correspondent to

\footnotetext{
30 The years prior to 1900 have been selected here to capture the period in which the Wairarapa wealthy cohort would have been most likely to run for office. Only Masterton, Greytown and Carterton and Pahiatua had Councils at this time. Recalling the physical location of the wealthy, as discussed in the first chapter, Pahiatua has been ignored here for the simple reason that none of the wealthy lived close enough to be reasonably considered as candidates for the mayoralty.

${ }^{31} \mathrm{~J}$. D. Heagerty and A. Booth were storekeepers and sawmillers (respectively) as well as farmers.

32 Of course, this was not all of the constituency, the obituaries presented at the beginning of this chapter demonstrate that at least some were in favour of the wealthy's involvement.

33 'Wairarapa North County Settler's Association', Wairarapa Daily Times, 1 November 1883, p.2.
} 
the Wairarapa Daily Times, argued that a key benefit of more intensive practices would be that "where one laborer is now employed 4 or 5 would be if the land was tilled. ${ }^{34}$ Even when the importance of the pastoralists was defended, they were seen as beneficial to the community rather than active within it. Another Wairarapa Daily Times editorial argued it was the runholder's money, rather than his activity that made him the community's 'best friend':

He spends more money in labor and stores than any other man among us... We do not always realise the extent to which we depend upon the lordly squatter... When wool goes down a penny a pound from ten to fifteen thousand pounds are lost to the Wairarapa labor market. ${ }^{3}$

This argument, which frames the trickle-down benefit of the runholder's economic existence as his primary role within the community, indicates that the pastoralist's perceived function in their community was secondary. ${ }^{36}$

The suggestion that the rich Wairarapa farmers' rural interests did not align with those of the town-is supported by Figure 16, an analysis of County Chairmen, who were much more likely to be farmers. ${ }^{37}$ Although of the wealthy testators only Booth, Maunsell and Pharazyn appear in Figure 16, several others were wealthy farmers. Duncan McGregor, who was Chairman of the Wairarapa North Council from 1883 to 1884, left an estate worth $£, 9,940$ when he died in $1912 \cdot{ }^{38} \mathrm{H}$. R. Bunny was the son of wealthy farmer and well-known politician Henry Bunny, and the brother-in-law of Edward Riddiford. Still others were directly related to the Wairarapa wealthy-Richmond Beetham's brothers

\footnotetext{
34 'The combination of Pastoral and Agricultural Pursuits', Wairarapa Daily Times, 6 December 1879, p.2 It is worth adding that the accessibility of this debate is limited by the availability of newspaper archives: to date only the conservative Wairarapa Daily Times has been digitised; the region's liberal paper, the Wairarapa Star, which was edited by Alexander Hogg, remains difficult to access.

35 'The Wool Season', The Wairarapa Daily Times, 12 October 1883, p.2.

36 As we shall see, pastoralists were busy cultivating communities of their own among their employees on the run.

${ }^{37}$ When the provinces were abolished in 1876, Wairarapa was divided into two County Councils: 'Wairarapa West and Wairarapa South', and 'Wairarapa East and Wairarapa North.' In the table below they are referred to simply as 'Wairarapa North' and 'Wairarapa South'. In 1888 Pahiatua was given its own County Council and in 1899 Councils were created for Akitio, Mauriceville and Eketehuna. As previously argued, these dates match imperfectly with the lives of the wealthy Wairarapa testators. Only those who were Chairmen before 1900 are listed in Figure 16. Once again, because of the wealthy's absence from Eketehuna and Mauriceville, these areas are ignored here.

38 'Deceased Person's Estates', W airarapa Age, 5 August 1913, p.6.
} 
George and William both appear in Figure 16, as does pastoralist James Armstrong's son Francis. Clearly, farmers occupied much more prominent positions in rural politics.

Figure 16: County Chairmen in Wairarapa, 1900-1910

\begin{tabular}{|l|l|l|l|}
\hline Chairmen & County & $\begin{array}{l}\text { When } \\
\text { Chairman }\end{array}$ & Occupation when elected \\
\hline F. Armstrong & Akitio & $1899-1900$ & Farmer (Pastoralist) \\
\hline G. Beetham & Wairarapa North & $1877-1883$ & Farmer (Pastoralist) \\
\hline D. McGregor & Wairarapa North & $1883-1884$ & Farmer \\
\hline T. Mackay & Wairarapa North & $1884-1888$ & Farmer (Pastoralist) \\
\hline W. H. Beetham & Wairarapa North & $1888-1893$ & Farmer (Pastoralist) \\
\hline F. von Reden & Wairarapa North & $1893-1896$ & Farmer (Intensive) \\
\hline R. Maunsell & Wairarapa North & $1896-1898$ & Farmer (Pastoralist) \\
\hline E. C. Smith & Wairarapa North & $1898-1900$ & Farmer (Intensive) \\
\hline J. Gilligan & Wairarapa South & 1877 & Farmer \\
\hline R. J. Barton & Wairarapa South & 1877 & Farmer (Pastoralist) \\
\hline J. Tully & Wairarapa South & $1877-1878$ & Farmer \\
\hline W. Booth & Wairarapa South & $1878,1882-$ & Sawmiller \\
\hline C. Pharazyn & Wairarapa South & $1878-1882$ & Farmer (Pastoralist) \\
\hline H. R. Bunny & Wairarapa South & $1887-1897$ & Farmer (Pastoralist) \\
\hline C. Elgar & Wairarapa South & $1898-1902$ & Farmer (Pastoralist) \\
\hline
\end{tabular}

If the wealthy pastoralists were so ill-suited (relatively) to community involvement, where did they direct their energies? One of the obvious responses is to note that the wealthy might have been rather more focused on making their own money. But while accumulation was self-evidently important, pastoralists were also busy fostering communities of their own-and unlike the 'official' community of the township, the pastoralists' communities existed in their very backyards.

\section{Pastoral Paternalism}

While pastoralists took little part in community affairs that did not directly affect them, they began to cultivate a paternal relationship with their employees as runs grew and

\footnotetext{
${ }^{39}$ Bagnall, pp.536-537.
} 
began to require extensive staff. McAloon has noted that 'a paternalistic benevolence, similar to the colonial squire, often characterised the relationship of urban employers with their employees,' but rural employers have been neglected. ${ }^{40}$ Maureen Evans, in her 1981 thesis, examined station life at two Wairarapa stations, viewing the relationship between runholders and their employees as 'co-operative' if 'patriarchal. ${ }^{41}$ This analysis represents a shift in focus in the rural workplace from the employee to the employer. John E. Martin, in The Forgotten Worker, argued that 'the organisation of labour on these huge estates resembled factory production. ${ }^{42}$ It was not only the way that labour was organised that mirrored urban forms of production, though; pastoralists also utilised the factory owner's paternalistic managerial approach.

When John Holmes - the son of Henry Holmes, a pastoralist at Matahiwi-left on a two-year trip to England he was farewelled by 'about twenty-five employés and past employés. ${ }^{43}$ A Mr. I. Sykes, spoke in favour of Holmes:

Mr I. Sykes, speaking as an ex employé, referred to the good fellowship that existed between the owners of Matahiwi and their employé. He said that Matahiwi stood out as an object lesson to all the employers in the Wairarapa and that there would be little need of Arbitration Boards if all the employers treated their servants as well as the Messrs Holmes. ${ }^{44}$

Holmes responded by saying 'he could not remember one single disagreeable occurrence with any of those present. ${ }^{45}$

Events like Holmes's departure were repeated numerous times. In 1894, William Bidwill (son of the deceased Charles Bidwill (d.1884, £29,971)) returned home from his honeymoon and was received by the employees of Pihautea Station. When the couple returned home they met an impressive welcome: 'A triumphal arch bearing the words

\footnotetext{
${ }^{40}$ McAloon, p.149.

${ }^{41}$ Maureen Evans, 'A Heritable Possession: A History of Akitio and Aramoana Stations, 1872 - 1942', MA Thesis, Victoria University of Wellington, 1981.

${ }^{42}$ John E. Martin, The Forgotten Worker: The Rural Wage Earner in Nineteenth-Century New Zealand, (Wellington, 1990), p.98 While Martin is talking about large-scale cropping, the same thing might be said about any rural enterprise in which large numbers of workers lived on site.

43 'Pleasing Incident at Matahiwi', Wairarapa Daily Times, 10 October 1904, p.5.

44 ibid.

45 ibid.
} 
'Welcome Home' was erected over the gate, and the Greytown Brass Band supplied the musical portion of the programme. ${ }^{46}$ In the evening,

Mr W. S. Wakelin, on behalf of the present and past employees, presented the happy couple with a very handsome plated combination dish... and an address expressive of the grateful esteem and lasting regard in which Mr Bidwill is held. ${ }^{47}$

Such evenings had a self-congratulatory air-employers and employees came together seemingly in celebration of the strength and cordiality of their relationship. Celebrations constructed the relationship as harmonious; delegitimising any discord among employees.

Employees may have had their own motivations for agreeing to celebrate their employer. Bidwill's reception and Holmes's party were not just opportunities (coerced or otherwise) for employees to express their 'gratitude' to their masters; in return employees benefited from their employer's hospitality. At Bidwill's reception,

A most enjoyable social was afterwards held, the music for the latter being supplied by the Greytown Band until mid-night...the dancing was kept up until the small hours to the tune of the banjo, cornet and violin respectively of private individuals. ${ }^{48}$

Of course, this is not to say that the employer-employee relationship favoured employees; it definitely did not. However, the employees' involvement in events and rituals that seemingly reinforced the employer's paternalism should not be read as endorsement of that relationship_employees may well have had their own, separate motivations.

This paternalistic relationship was cultivated by pastoralists, especially on the largest operations which housed many employees. In the 1880s, Brancepeth station (owned by the Beethams) was at its zenith. The station had reached approximately 75,000 acres and employed several hundred people. ${ }^{49}$ The Beetham's property, nineteen kilometres from a growing Masterton, was a semi-discrete community, separate but connected to the outside world. Employees on the station would be fed and housed but would also be provided for in other ways. Lydia Wevers notes that at Brancepeth there was

\footnotetext{
46 'Reception of Mr and Mrs. W. E. Bidwill', Wairarapa Daily Times, 23 May 1894, p.2.

47 ibid.

48 ibid.

49 Wevers, p.16.
} 
a schoolhouse with a schoolmaster for their [employees'] children, food, tobacco, stationery and other small wants and necessities; the usual cookhouse and sleeping whares; and a substantial station library. ${ }^{50}$

Why build a library on a sheep station? According to Wevers, family tradition has it that 'the library was established in part out of a wish to improve literacy among the workers. ${ }^{51}$ But if an ethos of betterment was the impetus for the library's creation, it does not explain its content. Wevers argues that the dominance of fiction (rather than improvement literature) in the Brancepeth library may suggest the importance of leisure over development. ${ }^{52}$ Regardless of the sincerity of the Beethams' stated intentions the library fits comfortably into the paternal rhetoric.

Paternalism was not generosity, though, and there is some evidence that runholders did not always view their employees with the affection that the squire mythology suggests. When Edward Riddiford (d.1911, f,584,622) retired from Te Awaiti he installed his brother-in-law, Oliver Bunny, as manager. Riddiford, however, remained heavily involved in operations, maintaining a remarkable, incessant stream of (mostly monodirectional) correspondence. Often, multiple letters were sent to Bunny on a single day. In one letter, Riddiford chastised Bunny for agreeing to pay an employee $f^{175}$, a sum that Riddiford deemed too high:

Parmer came to me in Featherston \& presented his order for $f_{175}$ - I must say I was surprised when you had told me that he would have about $f_{100}$ to take I said well Parmer how long have you been earning this he said about 16 or 18 months. You have had too high a price for your work he said I could have done it for less. If you apply again for work at Te Awaiti you must be content to take a less price. I gave him his cheque and left him. ${ }^{53}$

In another letter, sent directly to a Te Awaiti rabbiter five years later, Riddiford explained that the rabbiter would be receiving $£^{5}$ less than other employees because he had not

\footnotetext{
${ }^{50}$ Wevers, p.17 It is worth noting (as Wevers does) that Brancepeth was not the only $19^{\text {th }}$ century sheep station to boast a legitimate library. For a full discussion see Dulcie Gillespie-Needham, 'The Colonial and His Books: A Study of Reading in 19 ${ }^{\text {th }}$ Century New Zealand', PhD Thesis, Victoria University of Wellington, 1971.

51 Wevers, p.29.

52 ibid.. It should be noted that while the library's contents imply the importance of leisure rather than selfimprovement, the provision of employer-approved leisure activities (i.e. reading rather than drinking or gambling) was still a form of control.

${ }_{53}$ Letter from Edward Joshua Riddiford to Oliver Bunny, 4 August 1894, Riddiford Family Papers, MS Papers 5714-003, Alexander Turnbull Library, Wellington, New Zealand
} 
worked hard enough. ${ }^{54}$ While perhaps moderate, Riddiford's approach certainly contradicts the idea of the runholder as benevolent father; he appears rather as a shrewd manipulator. Riddiford's own farm diaries from Te Awaiti also record numerous actions that were far from paternal. In the most extreme incident, Riddiford struck an employee named Erskine because 'he said it was after hours and therefore he could not go for the cows. ${ }^{55}$ Elsewhere, Charles Vallance had an employee jailed for 48 hours for having left his property 'without the consent of his master."

While rural paternalism is emphasised here, some urban capitalists demonstrated similar tendencies; industries in which employers were in charge of large groups of employees appear to have been the same. When sawmiller William Booth (d.1903, $£ 88,208)$ died in March of 1903, for instance, his funeral procession was 'the largest ever witnessed in the district' and more than forty employees from Booth's mills attended. ${ }^{57}$ In Booth's case one can say with confidence that the constructed relationship disguised tension given that Booth 'axemen' struck for increased pay in $1900 .^{58}$ Instances of urban paternalism were limited in Wairarapa by the lack of employment opportunities in towns; as we have seen, urban forms of wealth accumulation were relatively rare.

Often, the runholder's paternalism has been seen as evidence of 'sheep lords" attempts to ape aspects of upper-class British life, but by comparing rural paternalism to that of the urban capitalist, this analysis argues for an understanding of the runholder within wider bourgeois identity. McAloon's 'paternalistic benevolence' of the South Island urban capitalist was also present in Wairarapa, but was matched by the relationship of runholder to employee on the sheep station: a significant point of difference between the North and South.

\footnotetext{
${ }^{54}$ Roberta Nicholls, 'Edward Joshua Riddiford', Dictionary of New Zealand Biography. Te Ara - the Encyclopedia of New Zealand, updated 30 October 2012 Riddiford also attempted to influence his employees to support the conservative candidate W. C. Buchanan over the liberal J. T. M. Hornsby for a seat in parliament.

55 Te Awaiti Diaries (Transcribed by D Glendining), 1863-1890, Riddiford Family Papers, MS Papers 65671, ATL.

${ }^{56}$ Bagnall, pp.476-477.

57 'The Funeral at Carterton', W airarapa Daily Times, 30 March 1903, p.2.

${ }^{58}$ Bagnall, p.479. Booth's bushmen received less than $£^{5}$ a month. They struck for a further sixpence per day, to which the manager 'promptly agreed.'
} 


\section{Charity}

Charity was another opportunity for the wealthy to be involved in community. Generally, this was an opportunity the wealthy did not take. The historiography of charity in New Zealand has tended to fall into one of two categories: either histories focus on the legislative and political history of welfare or they focus on specific charitable organisations. Scholars have been rather less interested in examining what charity might have meant to the charitable. ${ }^{59}$ McAloon argues that while "charitable and voluntary work was important, it was less so than in Britain' and that generally 'the main element in the self-consciousness of the wealthy was their role in developing a new colony. ${ }^{60}$ While McAloon's theory is hard to test, an analysis of the wealthy in Wairarapa clearly demonstrates that the rich tended not to be involved in charity.

The obituaries of the wealthy in Wairarapa rarely constructed philanthropy as a virtue; examples are notable in their scarcity. Alexander Sutherland (d.1877, £40,767) was listed as 'a kindly-natured man' and George Mace (d.1907, f43,401) was 'generally esteemed as a good friend and neighbour, a kindly employer of labor. ${ }^{61}$ When the pastoralist John Russell died in 1906, it was recorded that

Mr Russell was of a kindly nature, and it has been said of him that he never sent a 'swagger' away hungry, despite the fact that the sheep-farming class is frequently imposed upon by underserving mendicants. ${ }^{62}$

These few examples demonstrate that when generosity was constructed as a virtue in obituaries, it was a 'neighbourly' sort of generosity-there were no philanthropists in colonial Wairarapa.

Much more often, obituaries constructed the wealthy in the role of the 'pioneer'he who had played a vital role in 'building' the colony. Renall was 'one of the pioneers of

59 Most notably Margaret Tennant in Paupers \& Providers: Charitable Aid in New Zealand, (Wellington, 1989); David Thomson, A World Without Welfare: New Zealand's Colonial Experiment, (Auckland, 1998) and Linda Bryder, A Voice for Mothers: The Plunket Society and Infant Welfare, 1907-2000, (Auckland, 2003).

${ }^{60}$ McAloon, p.151.

61 'Obituary', Wairarapa Daily Times, 5 April 1907, p.5, 'Obituary', Evening Post, 22 October 1877, p.2.

62 'Mr John Purvis Russell', Wairarapa Daily Times, 2 March 1906, p.5 By framing itinerant labourers this way, the obituary reinforces an apparent division between the deserving and undeserving poor. McAloon found a similar tendency in the South Island (McAloon, pp.158-159. Feeding swaggers was an ongoing operation for large stations; Brancepeth saw 'between 350-550' swaggers a year between 1900 and 1908. (Wevers, pp.106107). 
the Colony, ${ }^{63}$ Henry Eglinton was a 'leading settler ${ }^{64}$ and Edwin Meredith 'was content to follow the career of a pioneer settler and of a good colonist' even though he 'was qualified to adorn a high public position. ${ }^{65}$ Most impressive was Henry Jackson (d.1905, £,19,759) of Greytown who was 'remembered as a patriarch in the land, who did his full share of work as a citizen, in the earlier and more trying days of this colony, and who now passes away full of years and full of honour. ${ }^{66}$ That these virtues were accentuated in obituaries adds further weight to a claim made by McAloon, that settlers constructed themselves as 'good colonists' as an alternative to the traditional middle-class identity of the 'charitable giver'. ${ }^{67}$

Evidently, then, the wealthy were not expected to be involved in charity. In practice, they did not subvert these expectations: charity appears to have been unimportant to the rich. Certainly, the only systematic record-charitable bequests left in the wills of the Wairarapa wealthy-suggests that charity was not prevalent. Only seven $(10.8 \%)$ of the cohort who left wills made bequests to charitable organisations. The most substantial of these bequests was made by Caroline Collins (d.1894, £11,881), who split almost her entire estate between the Wellington Society for the Aged and Needy, Wellington Hospital, and the Wellington Benevolent Society. ${ }^{68}$ William Booth left property in Christchurch and Wellington to Victoria College Council to assist

poor and deserving youths from any part of the Wellington Provincial District who give promise of unusual capacity for the purpose of spreading among the people a knowledge of those Economic Laws upon the observance of which the progress and security of the wage-earning classes must depend. ${ }^{69}$

Two others-Anders Andersen and Hanna Card-made contributions to hospitals of $£ 100$ and $£_{150}$ respectively. ${ }^{70}$ The remaining bequests classed here as 'charitable' were to local community groups and were benevolent but not as concerned with aiding the

${ }^{63}$ 'The Late Mr. A. W. Renall', Wairarapa Daily Times, 5 February 1902, p.3.

64 'Personal Matters', Evening Post, 31 October 1905, p.5.

65 'In Memoriam', Wairarapa Daily Times, 5 March 1907, p.5.

66 'Obituary', Wairarapa Daily Times, 9 May 1905, p.4.

${ }^{67}$ McAloon, pp.168-169.

${ }^{68}$ Collins Probate File, 1894, Series 6029, Accession W3265, No. 4419, ANZ/W.

${ }^{69}$ Booth Probate File, 1903, Series 6029, Accession W3265, No. 8270, ANZ/W. McAloon notes that 'a tendency to social engineering' was not uncommon in such bequests. p.158.

${ }^{70}$ Andersen Probate File, 1908, Series 6029, Accession W3265, Record No. 11333, ANZ/W; Card Probate File, 1912, Series 18576, Accession W5447, No. 40/12, ANZ/W. 
disadvantaged. Several bequests were to local churches and one, made by Charles Vallance, was to the Masterton Lodge of Freemasons. Testamentary charity was similarly rare in Canterbury and Otago, where $14 \%$ of the wealthy made 'some charitable provision. ${ }^{71}$

Opportunities for charitable contributions were not restricted to the testamentary moment and there is some evidence to suggest that during-life charity was more popular. While the end of an individual's life was a significant opportunity for charitable giving (the testator no longer needing their property), it left the benefactor unable to gain the benefits of status and reputation associated with philanthropy; during-life charity made more sense. What is more, this is supported by the data-the favouring of in-life charity over charitable bequests is borne out in the results. ${ }^{72}$ A 1904 report on Hospitals and Charitable Institutions in New Zealand recorded that the Wellington Charitable Aid district received only $f_{238}$ through bequests. By way of comparison, voluntary contributions made up f844 of the district's funds. The most significant contributions came from the Government $(£, 4,637)$ and from rates $(£, 3,722)$. Overall (in the whole colony) bequests contributed $f^{2,631}$ of the money accumulated by charitable aid boards, although the majority $(£ 1,796)$ of this came from North Canterbury. ${ }^{73}$

Private benevolence is much more difficult to track, but significant charitable activities by the wealthy in Wairarapa appear to have been rare. Small, private acts of 'neighbourly' charity are impossible to monitor in a systematic way, as are small acts of 'official' charity such as minor subscriptions to relief funds. As David Thomson notes, ' 5 /- given by a charitable aid officer leaves a paper trail, but $5 /$ - from a son does not. ${ }^{.74}$ In Wairarapa this means that although some acts of charity have been uncovered, it is difficult to evaluate the prevalence of 'minor charity'. We know, for example that in 1909 Charles Gawith made a donation of $\AA^{6} 6$ s towards the construction of the Renall-Solway

\footnotetext{
${ }^{71}$ McAloon, p.156.

72 McAloon, citing R.J. Morris, 'Reading the Will', notes that in England the evidence suggests the relative infrequency of end-of-life charity. Of course, it is impossible to identify, quantify and compare all forms of in-life charity with charitable bequests, but the evidence suggested here and in McAloon at the very least makes it clear that in-life charity was of an importance not immediately obvious from testamentary practices. 73 'Hospitals and Charitable Institutions of the Colony, (Report on the), by the Inspector of Hospitals, 1904, Appendix to the Journals of the House of Representatives, Session I, H-22, AtoJs.

${ }^{74}$ Thomson, p.128 Tennant also notes that 'informal assistance escapes detection.' Tennant, p.21.
} 
Home for the Aged in Masterton and that William Booth contributed $£, 5$ to the family of a man killed at the Masterton railway yards in $1908 .^{75}$ Others found different ways to contribute. John Cotter (d.1911, £24,158), the Greytown farmer, held a 'fete' on his property in 1904 for the benefit of the Wairarapa Hospital. Cotter's event raised $£ 100 .^{76}$ In the record, these examples are the exception rather than the rule, but countless other instances may have gone unrecorded-there is simply no way of knowing how prevalent such minor acts of charity were. ${ }^{77}$

We can say with a little more certainty that significant acts of 'official' charity were rare because when they did happen they were widely reported. When J. A. Renall, son of the developer Alfred William Renall, donated three and a half acres for the construction of Solway Home (a home for the aged that become Renall-Solway Home), Renall's donation received two full-length articles in the Wairarapa Daily Times. One article was published when the site for the home was chosen and the other at the home's opening, at which Renall claimed to have "only done his duty in the way of helping the poor and needy. ${ }^{, 78} \mathrm{It}$ is difficult to imagine significant acts of benevolence like Renall's remaining hidden; it seems altogether more reasonable to conclude that such 'major' charity did not occur.

Why were the wealthy so reluctant to help the needy? According to the conservative newspaper, The Wairarapa Daily Times, the availability of public welfare limited charity. The dispensation of aid in Wairarapa was organised through the North Wairarapa Benevolent Society, a 'separate institution' under the 1885 Hospitals and Charitable Institutions Act. In 1891, the Wairarapa Daily Times argued that the welfare system was a 'false system of benevolence. $^{79}$ The paper followed a typically Victorian argument against welfare, claiming that charitable aid was 'frittered away in doles which absolutely hinder the poor

\footnotetext{
75 'Local and General', Wairarapa Age, 15 December 1908, p.4 and 'Local and General', Wairarapa Daily Times, 12 April 1906, p.4.

76 'Local and General', Wairarapa Daily Times, 17 December 1904, p.4.

77 The importance of this unknown is debateable-it should be noted that small 'neighbourly' acts of charity while undoubtedly important are more difficult to see as expressions of status than are substantial acts of 'official' charity.

78 'Solway Home', Wairarapa Daily Times, 11 March 1905, p.5, 'Renall-Solway Home', Wairarapa Daily Times, 24 April 1906, p.6.

79 'Local and General', Wairarapa Daily Times, 15 August 1891, p.2.
} 
from helping themselves. ${ }^{80}$ By 1904, the paper was arguing that institutional welfare caused pauperism; charity encouraged 'indolence' in a way that private benevolence would not:

The Good Samaritan did not refer the man who fell among thieves to a Charitable Aid Board or a Benevolent Society. He simply helped him-did that which was necessary to relieve his distress. New Zealand is full of Good Samaritans who would do all that could be done for human derelicts but for the intervention of the Charity Organisations. ${ }^{81}$

It is improbable the privatisation of welfare would have done more for the poor, but there is some evidence to support the argument that institutionalised welfare disincentivised private benevolence; Tennant notes that donations to the Otago Benevolent Institution dropped from $£, 3,411$ in 1884 to $f, 512$ in 1886 after the passing of the Act. ${ }^{82}$ In Wairarapa, an 1885 Wairarapa Daily Times article complained that the society received five or fewer subscriptions per year. ${ }^{83}$ Yet if the availability of welfare was limiting private charity (in the form of donations to benevolent societies), there remained other ways of being involved in the dispensation of relief and here, too, the wealthy came up short.

The wealthy were not involved in the North Wairarapa Benevolent Society, the only significant official benevolent institution in the Wairarapa. Tennant argues that members of such institutions were 'farmers and businessmen, mostly elderly worthies capable of the most vituperative statements about the poor. ${ }^{84}$ Vituperative they may have been-the society was often reluctant to dispense aid to those seen as 'undeserving'-but they were not all 'worthies', at least not of the wealthy kind: none of the wealthy testators had a relationship with the benevolent society.

Why else might the Wairarapa wealthy have lacked the charitable impulse? In addition to its claims that welfare created 'paupers', the Wairarapa Daily Times argued that the region simply lacked enough poor individuals to sustain a welfare institution. Certainly, rural writers tended to characterise poverty as an urban problem: meetings of the United

\footnotetext{
${ }^{80}$ David Thomson notes a similar controversy about the Poor Laws in Britain. Thomson, p.128.

81 'Local and General', Wairarapa Daily Times, 26 July 1904, p.4.

82 Tennant, p.61.

83 'Local and General', Wairarapa Daily Times, 14 January 1885, p.2.

84 Tennant, p.60.
} 
Charitable Aid District (created by uniting Wellington and Wairarapa) were characterised by arguments over the appropriateness of Wairarapa rates being used to pay for 'their poor. ${ }^{85}$ Were there rural poor? The simple answer is 'yes'. The frequency of swaggers' stays at Brancepeth is testament enough to that. ${ }^{86}$ But the rural poor were also far less visible than in urban areas, and were much more likely to be itinerant. The North Wairarapa Benevolent Society certainly did not see itinerants as their problem. In 1908, the Benevolent Society had given relief to 301 individuals in the last year, of which 248 were 'casuals or persons passing through the town' and received 'temporary relief in the shape of train fares to other towns or accommodation for a night or more. ${ }^{87}$ On other occasions, newspaper reports of meetings recount the ways in which candidates were referred to the South Wairarapa or Castlepoint District Councils to apply for relief, the individual presumably falling outside of the North Wairarapa jurisdiction.

More generally, it might be argued that because poverty in the colonies was simply less prevalent than in Britain, the charitable-by-inclination, with no suffering to alleviate, simply kept their money in their pockets. This was another argument favoured by the Wairarapa Daily Times against the Benevolent Society. ${ }^{88}$ Margaret Tennant notes that this argument may well have its roots in early attempts to 'sell' New Zealand as a colony to potential settlers_-propagandists had little interest in admitting that the New World might also be suffering from Britain's social ills (albeit to a lesser extent). ${ }^{89}$ It matters less, however, whether or not New Zealand had 'enough' demand for charity; the fact of the matter is that there was certainly some demand. And in any case, an understanding of charity as an act of self-expression (rather than a response to need) means that a shortage of causes is beside the point. What matters is that there were causes and that the wealthy did not contribute.

Existing scholarship argues for an understanding of charity as important in helping to define British middle-class identity_charity imbued the middle classes with an aura of

\footnotetext{
${ }^{85}$ A.W. Hogg, Member for Masterton in Supply Debate, on the poor in Wellington and the role of the wealthy in alleviating: from 'Some of Our Wants', Wairarapa Daily Times, 20 September 1898, p.3.

${ }^{86} \mathrm{Up}$ to eighteen swaggers might arrive in a single day at Brancepeth, Wevers, p.106.

${ }^{87}$ Wairarapa Daily Times, 17 April 1909, p.4.

${ }^{88}$ Wairarapa Daily Times, 13 October 1880, p.2.

89 Tennant, p.11.
} 
worth and marked them as valuable and separate to the hereditary rulers of the upper classes. ${ }^{90}$ In New Zealand, where there was no hereditary landed class, capitalists had no threat to their legitimacy and so charity was no longer an important aspect of their identity. More important to middle-class identity seems to have been a reputation as 'colony builders,' as reflected in the rhetoric of the wealthy's obituaries in Canterbury, Otago and Wairarapa. This claim is difficult to test, but what matters above all else is that the wealthy moved away from charitable giving. However wealthy middle-class identity was to be defined in colonial New Zealand, it was a departure from the colonists' origins.

Charity could take forms other than the donation of money, and the (often nonmonetary) involvement of wealthy women in voluntary charitable organisations contrasts with the charity of wealthy men. Besides its semi-public Benevolent Society, Masterton also boasted a Dorcas Society (referred to alternately as Masterton Dorcas Society and Masterton Ladies' Dorcas Society) which was made up entirely of volunteer women and focussed on offering relief to the poor and needy, mostly through the donation of clothing. The group met fortnightly and published a list of donors in the Wairarapa Daily Times. Many of the wealthy families' names turn up on these lists. The names Vallance, Gawith and Cameron all turn up several times and some-Perry and Maunsell, for example-feature on the lists more often than not. The Dorcas Society's activities seem to have been relatively unofficial, and no systematic record of their work exists.

Women's involvement transcended the Dorcas Society. Although McAloon concludes 'the trustees of semi-official agencies such as Otago Benevolent Institution were all men,' this was not the case in Wairarapa. ${ }^{91}$ A Mrs. W. H. Nicholls, wife of the Masterton post-master, was involved in the North Wairarapa Benevolent Society from 1903 and took an influential role. The first report of a meeting in which Nicholls is mentioned records that she reported the only two cases that the board heard. ${ }^{92}$ In 1905 ,

\footnotetext{
${ }^{90}$ Davidoff and Hall, pp.416-450, McAloon, p.151 Also see, Michael Rose, 'Culture, Philanthropy, and the Manchester Middle Classes', in A. J. Kidd and K. W. Roberts (ed.), City, Class and Culture: Studies of Cultural Production and Social Policy in Victorian Manchester (Manchester, 1985). Similar conclusion have been made else where.

${ }^{91}$ McAloon, p.163.

92 ‘A Pitiful Case’, Wairarapa Daily Times, 10 September 1903, p.3.
} 
Nicholls was joined by another woman, a Mrs. J. Graham. ${ }^{93}$ When Nicholls resigned from the board in 1907 she was replaced by a Mrs. J. Cairns. ${ }^{94}$

Women may also have been more likely than men to favour charitable bequests. The structural barriers to women's direct inclusion in the group of wealthy Wairarapa testators in this thesis have been discussed in Chapter one, and while the four women who did die between 1876 and 1913 in Wairarapa with $£, 10,000$ or more are far too few to represent a statistically significant sample, it is worth considering that only five $(8.3 \%)$ out of sixty men made charitable bequests, two (50\%) out of four women did so. What is more, scholarship from elsewhere supports the belief that charitable bequests have tended to appear disproportionately often in women's wills. ${ }^{95}$

In Wairarapa, McAloon's claim that 'charity and philanthropy... seem to have been less important than in Britain or the United States' seems to be less true of women than it is of men. ${ }^{96}$ According to McAloon, women's activities were 'partly as a defence against charges of idleness, partly from genuine commitment' and 'such works of benevolence, combined with letters of introduction to the right people, could be very important in helping new arrivals to fit in. ${ }^{97}$ True enough, women's charitable work in Wairarapa was much more likely to be of the personal, 'face-to-face' variety than it was the work of statesupported institutions like the Benevolent Society, a distinction that marked it out as women's work. ${ }^{98}$ The charitable work of women was gendered but more work is necessary in order to investigate the ways in which charity might have been related to status. The typical solution-that women's charitable work was a function of gender whereas men's neglect of charity was a function of class-is insufficient. Elsewhere in the empire, historians have stressed that charitable work conveyed status and reinforced class

\footnotetext{
93 'North Wairarapa Benevolent Society’, Wairarapa Daily Times, 12 January 1905, p.3.

94 'Local and General', Wairarapa Age, 11 April 1907, p.4.

${ }^{95}$ Lebsock, pp.196-229.

${ }^{96}$ McAloon, p.168.

${ }^{97}$ McAloon, pp.163-164.

${ }^{98}$ Charitable work represented an extension of women's perceived domestic role. Margaret Tennant The Fabric of Welfare: Voluntary Organisations, Government and Welfare in New Zealand 1840-2005, (Wellington, 2007) pp.40-41.
} 
divisions. ${ }^{99}$ Further work is required in New Zealand to establish the ways in which women's charitable work symbolised middle-class respectability.

\section{Conclusion}

When the Wairarapa wealthy demonstrated a 'keen interest' in their community, they did so in ways that depended on divergent definitions of community and were conspicuously motivated by self-interest. Overall, opportunities for development were limited-such tasks tended to be undertaken by the Small Farms Association and later the Masterton and Greytown Lands Trusts. The wealthy still had opportunities to get involved in public, though, and an analysis of public roles demonstrates a lack of involvement here, too. Pastoralists, who were most likely to be divorced from the development of towns, fostered their own communities, cultivating paternal relationships with their employees at home on the run. This relationship served two purposes; it kept employees placated, and allowed employers to exert influence over their staff.

Generally, when it came to helping the poor, the elderly, and the otherwise disadvantaged, wealthy men were less inclined to offer their money, preferring to focus on private accumulation and the process of colony building. Wealthy women, though, seem to have taken a divergent approach and were often involved in charitable work. That this was so reflects the ideologies of gender which marked charity out as women's spherebut these roles were also about women defining status.

Stepping back, the wealthy's relationship with community marked a departure from their middle-class origins and represents the process of acclimatisation to the colonial class structure. With no one above them (socio-economically), capitalists no longer required charity to prove their usefulness. Instead, they could demonstrate their importance by doing their duty as 'good colonists'.

\footnotetext{
${ }^{99}$ Elizabeth Swain, 'Philanthropy in Birmingham and Sydney, 1860-1914: Class, Gender and Race', PhD Thesis, University College London, 2011.
} 


\section{Conclusion: Thinking Under and Across the Nation}

Histories that 'think under as well as across the nation' have two purposes, both demonstrated in this thesis. ${ }^{1}$ First, such regional histories have the power to show variations across the nation. Here, a regional focus has allowed this thesis to examine the extent to which we can generalise about New Zealand wealth. To do this, it has engaged with Jim McAloon's history of the South Island wealthy, No Idle Rich, attempting to identify the ways in which Wairarapa mirrored the South as well as those characteristics which made it an exception. To conclude, this chapter will compare-considering some of the ways in which this thesis contradicts and confirms South Island scholarship. In the way that this thesis adds another piece to New Zealand's puzzle, it resembles the regionally-focused social histories of W. J. Gardner, who first argued that 'a series of advanced regional studies may yield better results in social history than the analysis of national statistics. ${ }^{2}$

The other major strength of histories that think under the nation is the chance to see major forces on a smaller scale: within communities, families and individuals. Instead of attempting to generalise about large populations, regional histories allow a focus on smaller groups and thus illustrate the inconsistencies and complexities of individual identity. With this in mind, this chapter also aims to expand-it considers the ways in which the group of sixty-five wealthy Wairarapa testators show consistencies with and departures from their origins in the British middle classes.

This thesis first established a quantitative portrait of the wealthy Wairarapa testators, demonstrating that while farming was the wealthy's favoured method of accumulation, there were also a few urban wealthy who made their money as professionals or in the service industry. Within the farming rich, distinctions were made between large-scale pastoralism and intensive farming, and the operational characteristics of both were discussed. While early arrival was important for farmers (especially for pastoralists), it was less so for other forms of wealth accumulation. Chapter one also established the origins of

\footnotetext{
${ }^{1}$ As discussed in the introduction, such histories were called for by Tony Ballantyne in his recent Webs of Empire. Ballantyne, p.246.

${ }^{2}$ W. J. Gardner, p.25.
} 
the Wairarapa wealthy, demonstrating that contrary to a popular narrative of the colonial rich, the Wairarapa testators were near-exclusively of middle-to-lower class origins, rather than sons (or daughters) of the British aristocracy.

Chapter two focused on the wealthy in private. An analysis of the Wairarapa wealthy's testamentary practices demonstrated that wealth was accumulated for (and often, by) the family and that Wairarapa widows rarely occupied positions of significant economic agency in the affairs of their husbands' estates. Three main testamentary motives were identified: strategising for the future, promoting and reinforcing familial equality and the desire to leave a legacy.

Chapter three turned outwards from the private life of the wealthy to the cohort's public affairs; the roles (both official and unofficial) played by the wealthy in the development and maintenance of their communities. While publicly-minded individuals have been cast as either 'developers' or 'squires' in the South Island, this chapter demonstrated that associational development was more important in Wairarapa. This chapter also argued that generally, the rurality of the Wairarapa wealthy precluded them from occupying roles in local government. An analysis of the Wairarapa mayoralty demonstrated that roles in local politics went to individuals who were economically involved in the townships of Masterton, Greytown and Carterton-a population that was underrepresented in the cohort of wealthy testators. The pastoralists, those whose interests least lined up with townspeoples', cultivated their own communities by fostering a paternal relationship with the employees on the run. Chapter three also demonstrated that charity was of little importance to men, but was an important-seeming aspect of wealthy women's identity.

\section{Comparing}

McAloon's No Idle Rich has been, until now, a rare systematic study of the colonial wealthy in New Zealand. McAloon's work is restricted to the South Island; one function of this thesis has been to extend north. Of course, there is no reason to assume that the southern wealthy were replicated elsewhere-regional histories in New Zealand were simply too diverse. The differences are numerous, but two stick out. Wairarapa, unlike Canterbury and Otago, was separated from urban New Zealand by the imposing Rimutaka and Tararua ranges and so developed as a near-exclusively rural area. Because of this, farming fortunes dominated the wealthy in Wairarapa probably more than in any other region in New Zealand. Moving beyond Wairarapa, the North and South Islands experienced 
histories too different to assume commonality. Although tensions between Pākehā and Māori existed on both sides of the Cook Strait, the violence of the New Zealand Wars was largely restricted to the North Island. ${ }^{3}$

Despite the differences in circumstances, the Wairarapa wealthy did mirror Southern trends in several ways. The most obvious similarities are those established simply and empirically in Chapter one. In the North as in the South, the wealthy had their origins in the middle and lower classes of Britain 'and therefore had greatly improved their position by emigration. ${ }^{4}$ The similarities of origins led to similar attitudes towards wealth and the family, in both the North and South Islands 'the family was more closely involved in the process of accumulating and distributing wealth than statements of traditional ideology suggest. ${ }^{5}$ This thesis has argued, along with McAloon, for an understanding of the colonial wealthy within middle-class identity and against depictions by Eldred-Grigg et al. of the New Zealand rich as members of a colonial 'gentry.' There were also broad similarities in attitudes towards charitable giving. Most generally, charity seems to have been less important to the New Zealand wealthy, the idea of the rich as generous members of society being seemingly superseded by the perceived importance of being a 'good colonist.'

But this thesis has also found points of difference between the wealthy in Wairarapa and McAloon's rich. Most obviously, the rurality of Wairarapa meant that farming fortunes dominated urban wealth in Wairarapa far more than they did in the South Island. Chapter two has demonstrated that in the private sphere, Wairarapa widows occupied positions of economic agency in the distribution of their husbands' estates less often than did widows in the South Island. In Wairarapa, unlike the South Island, strained relationships between successful farmers and townspeople meant that the wealthy were probably less likely to occupy significant roles in local politics and development than were the South Island rich. Chapter three has demonstrated that these roles tended to be

\footnotetext{
${ }^{3}$ Having said this, Wairarapa was largely free of violence - in part because of the relationship fostered by the Māori-leaseholder economy - but the area's relative proximity to fighting was significant. Mostly non-violent tensions continued to develop, culminating in 'The Battle of Wairarapa Lakes' McIntyre, pp.91-92, pp.127140.

${ }^{4}$ McAloon, p.31.

${ }^{5}$ McAloon, p.93.
} 
occupied by townspeople who usually had more of an economic interest in the success of the town than did members of the wealthy cohort. Individual involvement in Wairarapa towns was also limited by associational development through the Small Farms Association and Lands Trusts, the prominence of which challenge existing understandings of development in New Zealand. Lastly, and perhaps most significantly, Chapter three also argued that the paternalism evident among urban capitalist (most commonly factory owners) in the South Island was replicated on the run by pastoralists. The big runs in Wairarapa were isolated communities towards which some wealthy pastoralists turned, having been spurned by local towns. This big pastoral paternalism recalled the controlling managerial style of the urban capitalist more than it did the largesse of the feudal lord and seems to have been more prevalent in the North Island than in the South.

As a locally-focused social history, then, this thesis expands our view of wealthy identity in New Zealand, but gaps in our knowledge still exist. It remains to be seen, for example, how representative Wairarapa might have been of the wider North Island. What is more, both this study and McAloon's have been focused on New Zealand's leeward side in areas most suited to pastoralism. What did wealth-holding look like in areas where the land was simply unsuited to the same sort of industries, for example the South Island's West Coast or Northland? More regional study is required to complete the picture.

\section{Expanding}

This thesis focused on the wealthy in Wairarapa but has implications for the wider North Island, New Zealand and, beyond that, the dynamics of colonial identity. The arguments made in this thesis come from, and reinforce an understanding of settlers as products of the tension between their origins and their destinations. Chapter two demonstrated that $60 \%$ of the Wairarapa wealthy had their origins in the lower middle classes, but through early arrival and access to capital (among other advantages and coincidences) the wealthy were able to improve their social standing. How should these individuals-relatively new to this level of wealth and status (bar a few notable exceptions) — act? Would they adopt 
the identity of the British upper classes, or would they maintain the identity of their origins-built by the values of hard work, thrift and family wealth? ${ }^{6}$

In their private lives, the Wairarapa wealthy reflected their origins as members of the middle class. Chapter two demonstrated that wealth accumulation was about the family in two key ways: firstly that the family was actively involved in wealth accumulation and secondly that the family was the primary motivation for making money. Testamentary practices made this last point clear enough; wealth was spread evenly within the family. What is more, the rich formed conscious plans for the family's long-term economic survival-future generations were favoured over the present, most visibly illustrated by the favouring of daughters over widows. This importance of the family to wealth (as well as these specific testamentary practices) identifies the Wairarapa wealthy's commitment to partible inheritance, an important aspect of middle-class identity. In private, then, the wealthy's practices were consistent with their origins in the British middle classes.

In their public lives, however, the Wairarapa wealthy moved away from their origins. Charitable activity had been an important aspect of middle-class identity in Britain, singular in its ability mark the middle classes as separate to (and legitimate despite) the upper classes, who inherited their status from previous generations. In the colonies, charitable activity was markedly less important to the wealthy and while certainly charitable opportunities may have been fewer, this does not fully explain divergent attitudes to charity. Clearly, charitable giving was no longer an important aspect of wealthy capitalist identity. In some aspects of their public lives, the wealthy had deviated from their origins.

Why did the wealthy maintain middle-class identity in private but begin to form a separate identity in public? The importance of a lack of an upper class (in the British, aristocratic sense) is difficult to overstate. With no upper class against which to define themselves, it was no longer important that capitalists find charitable uses for their money to legitimise their social position. This explains why the wealthy were no longer interested

\footnotetext{
${ }^{6}$ Of course, proposing questions of identity as conscious is misleading; questions of identity rarely manifest on a conscious level. The idea of class-consciousness - that is, in the crudest terms, the association of certain habits and matters of identity to a given individual's economic position-implies a certain lack of agency (let alone consciousness) in the development of identity.
} 
in charity. Instead, the capitalists could legitimise their position by advancing the young colony.

In private, things were different. The testamentary practices of the middle classesthe dominance of partible inheritance over primogeniture-had never been about legitimising the middle classes against the upper classes; equal division was simply the most sensible (in terms of securing family fortunes) decision for bourgeois families in a capitalist society. Partible inheritance allowed the middle-class family to spread the risk of financial failure between family members, providing an expanded safety net. What is more, the middle classes were (in part) defined by the necessity of work to their continued success and status. All the children would need a share of the family fortune if they were to succeed as capitalists. A New World, and one without a gentry, did nothing to change this facet of middle-class identity; partible inheritance (and more widely, the links between wealth and the family) remained as important and so the wealthy stuck to their origins.

The answer then, is expedience. The public lives of the wealthy had always been about status (rather than survival) and so when the rules of the game changed, so too did the public lives of the wealthy. Economic survival, however, remained a priority. The middle classes would still need to ensure that the whole family worked and wealth and risk would still need to be spread evenly if the New Zealand wealthy were going to succeed. 


\section{Bibliography}

\section{Primary Sources}

\section{Manuscripts and Archives}

\section{Archives New Zealand}

Probate Files (Wellington and Masterton Courts), Archives New Zealand, Wellington, 1876-1913.

Testamentary Registers (Wellington), Archives New Zealand, Wellington, 1876-1913.

\section{Alexander Turnbull Library}

Henry Holmes Papers, MS-Papers-6359.

Peter Hume Papers, MS-Papers-11100.

Beach Family Papers, 89-266-6-16.

Mantell Family Papers, MS-Papers-0083.

William Ronaldson Papers, MS-Papers-1720.

Donald McLean Papers, MS-Papers-0032-0439.

John Reynolds Papers, Micro-MS-0430.

Beetham Family Papers, MS-Papers-0037-030.

Riddiford Family Papers, MS-Group-0441.

Charles Augustus Vallance Papers, MS-Papers-2637.

\section{Published Sources}

Bernard Burke, A Genealogical and Heraldic History of the Colonial Gentry, (London: Harrison \& Sons, 1891).

Cyclopedia Publishing Company, The Cyclopedia of New Zealand, Taranaki Hawke's Bay \& Wellington Provincial Districts, (Christchurch: Cyclopedia Company Ltd., 1908).

Cyclopedia Publishing Company, The Cyclopedia of New Zealand, Wellington Provincial Districts, (Wellington: Cyclopedia Company, Ltd., 1897).

Meredith, Edwin, Biographical Sketch: Reminiscences and Experiences of an Early Colonist, (Masterton: E. H. Waddington, 1898).

New Zealand Parliamentary Debates: Legislative Council and House of Representatives

Official New Zealand Yearbook, years 1893-1910, accessed through www.stats.govt.nz. 


\section{Newspapers}

Evening Post

Hawke's Bay Herald

New Zealand Colonist and Port Nicholson Advertiser

New Zealand Gazette and Wellington Spectator

Wairarapa Age

Wairarapa Daily Times

Wellington Independent

\section{Secondary Sources}

\section{Books}

Arnold, Rollo, New Zealand's Burning: The Settler's World in the mid-1880s (Wellington: Victoria University Press, 1994).

Bagnall, A.G., Wairarapa: An Historical Excursion, (Masterton: Hedley's, 1976).

Ballantyne, Tony, Webs of Empire (Wellington; Bridget Williams, 2012).

Bannister, Charles, Early History of the Wairarapa, (Cadsonbury Publications, 1999)

Belich, James, Making Peoples: A History of the New Zealanders from the 1880s to the year 2000, (Auckland: Allen Lane, 1996)).

Bidwill, William, Bidwill of Pihautea: The Life of Charles Robert Bidwill, (Christchurch: 1927).

Brooking, Tom \& Pawson, Eric (eds), Seeds of Empire: The Environmental Transformation of New Zealand, (London, I.B. Tauris, 2011).

Brooking, Tom \& Pawson, Eric, Environmental Histories of New Zealand, (Melbourne: Oxford University Press, 2002).

Bryder, Linda, A Voice for Mothers: The Plunket Society and Infant Welfare, 1907-2000, (Auckland: Auckland University Press, 2003).

Bull, B. H., The Years Between: Greytown Borough Centennial, 1878-1978, (Carterton: Roydhouse, 1986).

Carle, C.J. A Gateway to Wairarapa, (Featherston: Featherston Borough Council, 1957)

Cockburn, R., Pastoral Pioneers of South Australia, (Adelaide: Publishers Limited, 1925).

Daunton, Martin (ed.), Self-Interest and Welfare in the English Past, (London: University College London, 1996).

Davidoff, Leonore \& Hall, Catherine, Family Fortunes, (Chicago: University of Chicago Press, 2002).

Denoon, Donald, Settler Capitalism: The Dynamics of Dependent Development in the Southern Hemisphere, (New York: Oxford University Press, 1983).

Dickey, Brian, No Charity There: A Short History of Social Welfare in Australia, (Sydney: Allen \& Unwin, 1987). 
Donald, Graham, From Tulliallan to Tarureka: The History of James and Elizabeth Donald Featherston and their descendant's, (Self-published, 1990).

Eldred-Grigg, Stevan, A Southern Gentry: New Zealanders Who Inherited the Earth, (Wellington, AH \& AW Reed, 1980).

Eldred-Grigg, Stevan, The Rich (Wellington: Heinemann Reed, 1996).

Fairburn, Miles, Nearly Out of Heart and Hope: The Puzzle of a Colonial Labourer's Diary, (Auckland: Auckland University Press, 1995).

Fargher, Ray, The Best Man Who Ever Served the Crown?: The Life of Donald McLean, (Wellington: Victoria University Press, 2004).

Fyfe, Frank, Morvern to Glenmorven, (Masterton: self-published, 2000).

Gardner, W.J. A Pastoral Kingdom Divided: Cheviot 1889-1894 (Wellington: Bridget Williams, 1992).

Gardner, W.J. Where They Lived: Studies in Local, Regional and Social History, (Christchurch: Regional Press, 1999).

Goldsmith, Paul, The Bidwills, (Auckland: David Ling, 2012).

Graham, Jeanine, Frederick Weld (Auckland: Auckland University Press, 1983).

Grant, Ian (ed.), The Memoirs of Joseph Masters, (Masterton: Wairarapa Archive, 2005).

Green, David and Owens, Alistair, (ed.) Family Welfare: Gender Property and Inheritance since the Seventeenth Century, (London: Praeger, 2004).

Green, David; Owens, Alastair; Maltby, Josephine; Rutterford, Janette (ed.), Men, Women and Money: Perspectives on Gender, Wealth and Investment 1850-1930, (Oxford: Oxford University, 2011).

Gunn, Simon, The Public Culture of the Victorian Middle Class: Ritual and Authority and the English Industrial City, (Manchester: Manchester University Press, 2000).

Hamer, David, New Towns in the New World: Images and Perceptions of the Nineteenth-Century Urban Frontier, (New York: Columbia University Press, 1990).

Hamer, David \& Nicholls, Roberta (Ed.) The Making of Wellington 1800-1914, (Wellington: Victoria University Press, 1990).

Hareven, T.K. (ed.) Transitions: The Family and the Life Course in Historical Perspective, (New York: New York Academic Press, 1978).

Henderson, Alan, Fortuitous Legacy: The Masterton Trust Lands Trust 1872-1997, (Masterton: Masterton Trust Lands Trust, 1997).

Holmes, Robin \& Farley, Allan (ed.), Dear Sister: Letters Between a Pioneer Wairarapa Family and Relatives in Rural England 1856-1883, (Masterton: Wairarapa Archive, 2006).

Hunt, Graeme, The Rich List: Wealth \& Enterprise in New Zealand 1820-2000, (Reed, 2000).

Joblin, Dorothea, The Colonial One: Lorna Monckton of Newstead, (Christchurch: Whitcombe and Tombes, 1975).

Kidd, A. J. and Roberts, K. W., (ed.), City, Class and Culture: Studies of Cultural Production and Social Policy in Victorian Manchester (Manchester: Manchester University Press, 1985).

Lebsock, Suzanne, The Free Women of Petersburg: Status and Culture in a Southern Town, 17841860, (New York: W.W. Norton, 1984). 
Martin, John E., The Forgotten Worker: The Rural Wage Earner in Nineteenth-Century New Zealand, (Wellington: Allen \& Unwin, 1990).

McAloon, Jim, No Idle Rich: The Wealtby in Canterbury \& Otago 1840-1914 (Dunedin: University of Otago Press, 2002).

McCallum, Angus, A Meeting of Gentlemen on Matters Agricultural: The Masterton Show 18711986, (Masterton: Masterton Agricultural and Pastoral Association, 1986).

McIntyre, Roberta, The Canoes of Kupe: A History of Martinborough District, (Wellington: Victoria University Press, 2002).

Morris, R. J., Men, Women and Property in England, 1780-1870: A Social and Economic History of Family Strategies amongst the Leeds Middle Class, (Cambridge: Cambridge University Press, 2005).

Oliver, W.H. \& Williams, B.R. (ed.) \& Rice, Geoffrey (rev.) The Oxford History of New Zealand, (Oxford: Oxford University Press 1992).

Peden, Robert, Making Sheep Country: Mt. Peel Station and the Transformation of the Tussock Lands, (Auckland: Auckland University Press, 2011).

Pitt, David, Social Class in New Zealand, (Auckland: Longman Paul, 1977).

Richardson, Len \& McIntyre, W. D. (ed.), Provincial Perspectives: Essays in honour of W. J. Gardner, (Christchurch: University of Canterbury, 1980).

Riddiford, Helen, A Blighted Fame: George S. Evans 1802-1868, A Life, (Wellington: Victoria University Press, 2014).

Rubinstein, W.D., Men of Property: The Very Wealthy in Britain since the Industrial Revolution, (London: Croom Helm, 1981).

de Serville, Paul, Pounds and Pedigrees: The Upper Class in Victoria 1850-1880, (Melbourne: Oxford University Press, 1991).

Smout, T. C. (ed.), The Search for Wealth and Stability: Essays in Economic and Social History Presented to M.W. Finn (London: Macmillan, 1979).

Takinini, J. McIntosh, The Renall Years, 1813-1986, (self-published, 1986).

Tennant, Margaret, Paupers and Providers: Charitable Aid in New Zealand (Wellington; Allen \& Unwin, 1989).

Tennant, Margaret, The Fabric of Welfare: Voluntary Organisations, Government and Welfare in New Zealand, 1840-2005, (Wellington: Bridget Williams, 2007).

Tenquist, John (ed.), Yarns of our Youth 1874-1945, (WOOPS, n.d).

Thomson, David, A World Without Welfare: New Zealand's Colonial Experiment (Auckland; Auckland University Press, 1998).

Von Grondelle, Carole, Angel of the Anzacs: The Life of Nora Luxford, (Wellington: Victoria University, , 2000).

Waitangi Tribunal, The Wairarapa Ki Tararua Report, (Wellington: Legislation Direct, 2010).

Wevers, Lydia, Reading on the Farm: Victorian Fiction and the Colonial World, (Wellington: Victoria University Press, 2010).

Wily, Henry \& Maunsell, Henry, Robert Maunsell: A New Zealand Pioneer, (Dunedin, Reed, 1938). 
Yerex, David, They Came to Wydrop: The Beetham and Williams Families, Brancepeth and Te Parae, Wairarapa 1856-1990 (Masterton, Self-published, 1991).

\section{Articles}

Armstrong W. and Ehrnsaft, P., 'Dominion Capitalism: A first statement' Australian and New Zealand Journal of Sociology, vol. 16, 1978, pp.352-63.

Beilharz, Peter \& Cox, Lloyd, 'Settler Capitalism', Thesis Eleven, vol. 88, no. 112, 2007, pp.112-124.

Bertocchi, Graziella, 'The Law of Primogeniture and the Transition from Landed Aristocracy to Industrial Democracy', Journal of Economic Growth, vol. 11, no. 1, 2006, pp.43-70 .

Bradbury, Bettina, 'From Civil Death to Separate Property: Changes in the Legal Rights of Married Women in Nineteenth-Century New Zealand, New Zealand Journal of History, vol. 29, no. 1, 1995, pp.40-66.

Daunton, Martin, “Gentlemanly Capitalism' and British Industry 1820-1914', Past and Present, vol. 122, 1989.

Di Matteo, Livio, 'Wealth Accumulation Motives: Evidence from the Probate Records of Ontario, 1892 and 1902,' Cliometrica, vol. 2, 2008, pp.143-171.

Dooling, Wayne, 'The Making of a Colonial Elite: Property, Family and Landed Stability in the Cape Colony, c.1750-1834', Journal of Southern African Studies, vol. 31, no. 1, 2005, pp.147-162.

Fairburn, Miles, 'Social Mobility and Opportunity in Nineteenth-century New Zealand', New Zealand Journal of History, vol. 13, no. 1, 1979, pp.43-64.

Fairburn, Miles, 'Local Community or Atomized Society?: The Social Structure of Nineteenth-Century New Zealand', New Zealand Journal of History, vol. 16, no. 2, 1982, pp.146-167.

Hamer, David, 'Towns in Nineteenth-Century New Zealand', New Zealand Journal of History, vol. 13, 1979, pp.5-24.

Hopkins, A.G., 'Gentlemanly Capitalism in New Zealand'. Australian Economic History Review, No 11, vol. 43, no. 3, 2003, pp.287-297.

Littlewood, Michael, 'The History of Death Duties and Gift Duty in New Zealand', New Zealand Journal of Taxation Law and Policy, vol. 18, no. 1, pp.66-92.

McAloon, Jim, 'Gentlemanly Capitalism and Settler Capitalists: Imperialism, Dependent Development and Colonial Wealth in the South Island of New Zealand', Australian Economic History Review, vol. 42, 2002, pp.287-297.

Owens, Alistair, Green, David, Bailey, C \& Parkinson, A, 'A Measure of Worth: probate valuations, personal wealth and indebtedness in England 1810-1840' Historical Research, vol. 79, 2005 pp. 383-403.

Owens, Alistair, 'Property, Gender and the Life Course: Inheritance and Family Welfare Provision in Early Nineteenth-Century England', Social History, vol. 26, no. 3, 2001, pp.299-317. 
Owens, Alastair \& Green, David, 'The Final Reckoning: Using Death Duty Records to Research Wealth Holding in Nineteenth-century England and Wales', Archives, vol. 66, no. 3, 2013, pp.1-21.

Patterson, Brad, 'Laagers in the Wilderness: The Origins of Pastoralism in the Southern North Island Districts, 1840-1855', Stout Centre Review, vol. 1, no. 3, 1991, pp.3-14.

Rubinstein, W.D., 'The Top Wealth-holders of New South Wales, 1817-1939', Australian Economic History Review, vol. 20, no. 2, 1980, pp.136-152.

Shanahan, Martin, 'Personal Wealth in South Australia', Journal of Interdisciplinary History, vol. 32, no. 1, 2001 pp.55-98.

Thompson, F. M. L., 'How Successful Nineteenth-Century Businessmen Disposed of Their Fortunes', The Economic History Review, vol. 43, no. 1, 1990, pp.40-61.

Weaver, John C, 'Frontiers into Assets: The Social Construction of Property in New Zealand, 1840-65', The Journal of Imperial and Commonwealth History, vol. 27, no. 3, 1999, pp.17-54.

\section{Theses}

Campbell, Michael, 'The Evolution of Hawke's Bay Landed Society', PhD Thesis, Victoria University of Wellington, 1972.

Evans, Maureen, 'A Heritable Possession: a History of Akitio and Aramoana Stations, 1872 - 1942', MA Thesis, Victoria University of Wellington, 1981

Galt, Margaret, 'Wealth and Income in New Zealand, c. 1870 - c. 1939', PhD Thesis, Victoria University of Wellington, 1985.

Hambly, Raymond Ernest, 'Dairying in the Wairarapa: A Socio-economic Survey Interpreted in Terms of Historical Small Farm Settlement', MA Thesis, Victoria University of Wellington, 1966.

Hill, R.D., 'The Land and the Squatter-Wairarapa 1843-1853', M.A. Thesis, Victoria University, 1962.

Klaus, Judy Ann, 'Shearers Wearing Shakespeare: How Unique was Brancepeth Station Library in the late 1800s?', Master of Library and Information Studies Thesis, Victoria University of Wellington, 1999.

Nicholls, Roberta, 'Wellington Magnate: The Honourable John Martin, his Children and their Milieu, 1841-1918', MA Thesis, Victoria University of Wellington, 1985.

Swain, Elizabeth Abigail Harvey, 'Philanthropy in Birmingham and Sydney 1860-1914: Class, Gender and Race', PhD Thesis, UCL, 2011.

Wyse, Stephanie Jessica 'Gender, Wealth and Margins of Empire: Women's economic Opportunity in New Zealand cities, c.1890-1950', PhD Thesis, Kings College, London, 2008.

\section{Online Sources}

Ballara, Angela and Carter, Mita, 'Te Hiko Piata Tama-i-hikoia', The Dictionary of Nen Zealand Biography, Te Ara—the Encyclopedia of New Zealand, updated 28 August 2014. 
Boyd, Mary, 'Russell, Henry Robert', Dictionary of New Zealand Biography. Te Ara - the Encyclopedia of New Zealand, available at http://www.teara.govt.nz, updated 28 January 2014.

McGibbon, Ian, 'Tiffen, Henry Stokes', Dictionary of New Zealand Biography. Te Ara - the Encyclopedia of New Zealand, available at http:/ / www.teara.govt.nz, updated 30 October 2012.

McGlone, Matt, 'Ecoregions - Nine ecoregions', Te Ara - the Encyclopedia of New Zealand, available at http://www.teara.govt.nz, updated 13 July 2012.

'Inflation Calculator', Reserve Bank of New Zealand, available at: http:/ / www.rbnz.govt.nz, accessed on 21 May 2015.

Swarbrick, Nancy, 'Logging Native Forests', Dictionary of New Zealand Biography. Te Arathe Encyclopedia of New Zealand, available at http://www.teara.govt.nz, updated 13 July 2012. 